\title{
Brachiopod faunas from the basinal facies of southeastern Thuringia (Germany) before and after the Hangenberg Crisis (Devonian-Carboniferous boundary)
}

\author{
Bernard Mottequin, Konrad Bartzsch, Eric Simon, and Dieter Weyer
}

\begin{abstract}
Upper Famennian-Tournaisian (Hastarian) brachiopods from the deep-water, mixed siliciclastic-carbonate Gleitsch Formation (Breternitz and Pfaffenberg members) of southeastern Thuringia (mainly from the Saalfeld area, Germany) are described systematically. A new Tournaisian rhynchonellide genus (Thuringorhynchus gen. nov.) and four new Tournaisian species are described (Productina saalfeldensis sp. nov., Thuringorhynchus pseudoequitans gen. et sp. nov., Cleiothyridina pfaffenbergensis sp. nov., and Crassumbo germanicus sp. nov.). Moreover, the lectotype of "Lingularia" straeleni (Demanet, 1934), from the Tournaisian of Belgium, is selected. Prior the Hangenberg Crisis, the brachiopod assemblage (10 species) of the Breternitz Member (upper and uppermost Famennian) is strongly dominated by species belonging to smooth to poorly ornamented rhynchonellide genera (Hadyrhyncha, Novaplatirostrum, Rozmanaria, and rozmanariid? gen. indet.) notably reported from Laurussia and the northern margin of Gondwana. The onset of the Hangenberg Crisis is marked by an anoxic black shale horizon at the top of the Breternitz Member followed by the siltstones and turbiditic sandstones of the Obernitz Member; both horizons did not yield brachiopods.

A completely changed, more diverse brachiopod assemblage (15 species) existed in the Pfaffenberg Member (Tournaisian, lower Hastarian), which also included a basal $20 \mathrm{~cm}$ "topmost Famennian" (according to the current, soon abandoned definition of the Carboniferous base using Siphonodella sulcata as criterion), but clearly dated as upper Protognathodus kockeli Zone). Small-sized productidines (Productina) and spiriferides (Crassumbo, Texathyris?) dominate; a probable complete turnover is recorded among the Rhynchonellida (Thuringorhynchus). The rapid recovery after the drastic Hangenberg extinction event includes species belonging to pre-existing genera and to new ones.
\end{abstract}

http://zoobank.org/5EAD326D-41D7-4445-8D43-3BBD6FF9BC20

Mottequin, Bernard, Bartzsch, Konrad, Simon, Eric, and Weyer, Dieter. 2019. Brachiopod faunas from the basinal facies of southeastern Thuringia (Germany) before and after the Hangenberg Crisis (Devonian-Carboniferous boundary). Palaeontologia Electronica 22.1.16A 1-54. https://doi.org/10.26879/833

palaeo-electronica.org/content/2019/2454-brachiopods-from-thuringia

Copyright: April 2019 Paleontological Society.

This is an open access article distributed under the terms of Attribution-NonCommercial-ShareAlike 4.0 International (CC BY-NC-SA 4.0), which permits users to copy and redistribute the material in any medium or format, provided it is not used for commercial purposes and the original author and source are credited, with indications if any changes are made.

creativecommons.org/licenses/by-nc-sa/4.0/ 
Bernard Mottequin. Royal Belgian Institute of Natural Sciences, Operational Directorate Earth and History of Life, rue Vautier 29, B 1000 Brussels, Belgium. bmottequin@naturalsciences.be

Konrad Bartzsch. Stauffenberg-Strasse 68, D-07318 Saalfeld, Germany.

Eric Simon. Royal Belgian Institute of Natural Sciences, Operational Directorate Earth and History of Life, rue Vautier 29, B 1000 Brussels, Belgium. (Deceased on 11 February 2018)

Dieter Weyer. Museum of Natural History (Leibniz Institute) at Humboldt University, Invalidenstrasse 43, D10115, Berlin, Germany. dieter.weyer@t-online.de

Keywords: Brachiopoda; Famennian; Tournaisian; Hangenberg Crisis; Thuringia; Germany

Submission: 6 November 2017. Acceptance: 25 February 2019.

\section{INTRODUCTION}

Worldwide, the mostly rare Famennian and basal Tournaisian Brachiopoda of aphotic zones (cephalopod limestones, "cypridinic" = entomozoid shales) are not well known and often remained even uncollected. Primary studies started in Germany with Count Georg Münster (1776-1844). After his outstanding ammonoid research (in 18321839), he published a monograph (Münster, 1840) of the complete faunal content in Upper Devonian limestones of Upper Franconia (mainly localities Schübelhammer, Gattendorf). His data (eight species from Schübelhammer and Geuser) are still unrevised. Nowadays, such a task would be extremely difficult due to the loss of his collections (excepting figured specimens) preserved in the Bayerische Staatssammlung Paläontologie at the university of München during the war 1944-1945 and with no chance to recollect in the gone quarry parts. Only one of his species, Terebratula subun- data Münster, 1840 (homonym of the Cretaceous Terebratula subundata J. Sowerby, 1813; see below), is re-determined here as Rozmanaria equitans (Schmidt, 1924), using the holotype in München.

Münster (1840, p. 115, 120) had discussed the age of his "Uebergangskalk" (transitional limestone) with Roderick Impey Murchison (17921871) and Adam Sedgwick (1785-1873) in 1839 (during their visit in Bayreuth city). He opposed the suggestion of the British geologists (Devonian age according to the British sequence, just proposed in 1839) and speculated about a position between the Cambrian and "Silurian" systems. Today, Münster's limestone localities are reassigned as Ludlow (Orthoceratenkalk of Elbersreuth) and to different ammonoid "stages" of the Famennian (Cheiloceras-Wocklumeria).

Immediately after Münster, similar palaeontological studies of the now classical Bohlen section near Saalfeld in Thuringia (Figures 1, 2.1) were

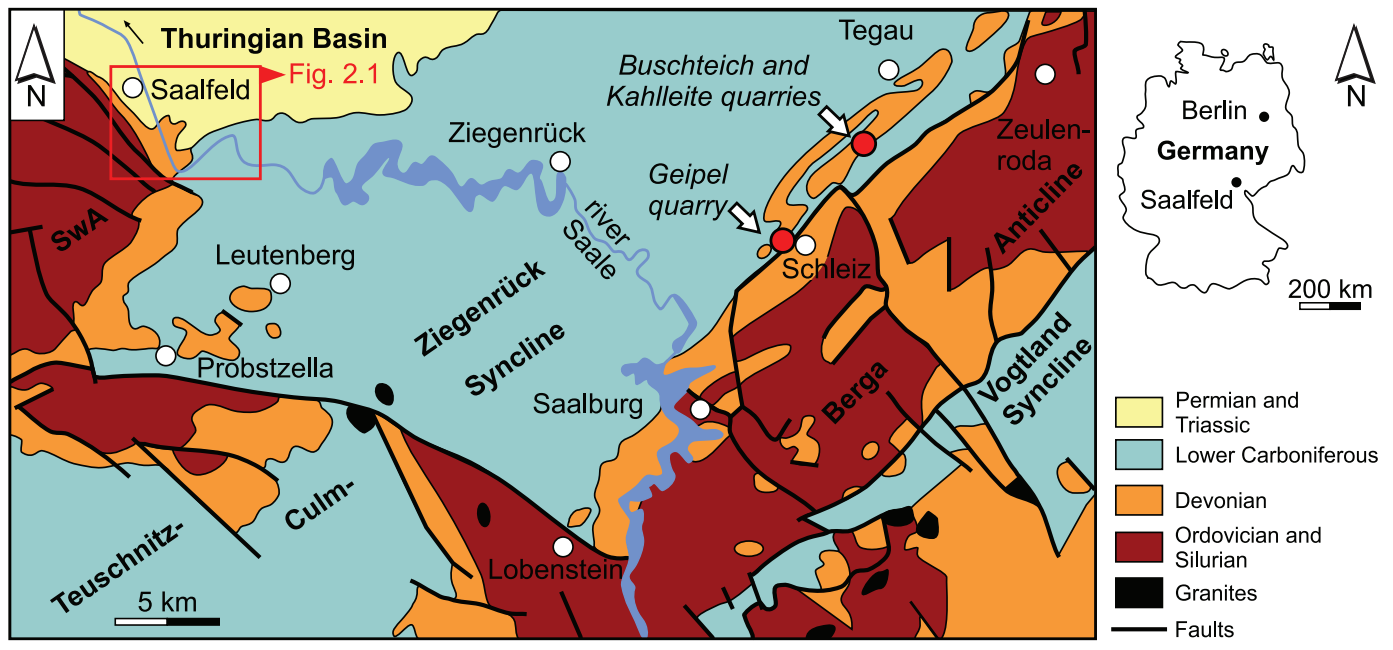

FIGURE 1. Schematic geological map (modified from Weber, 1955) of SE Thuringia (Thuringian Slate Mountains) localities with top Famennian and/or basal Tournaisian sections on the SE flank of Schwarzburg Anticline (SwA), southeast of Saalfeld, and on the NW flank of Berga Anticline, west and north of Schleiz. 

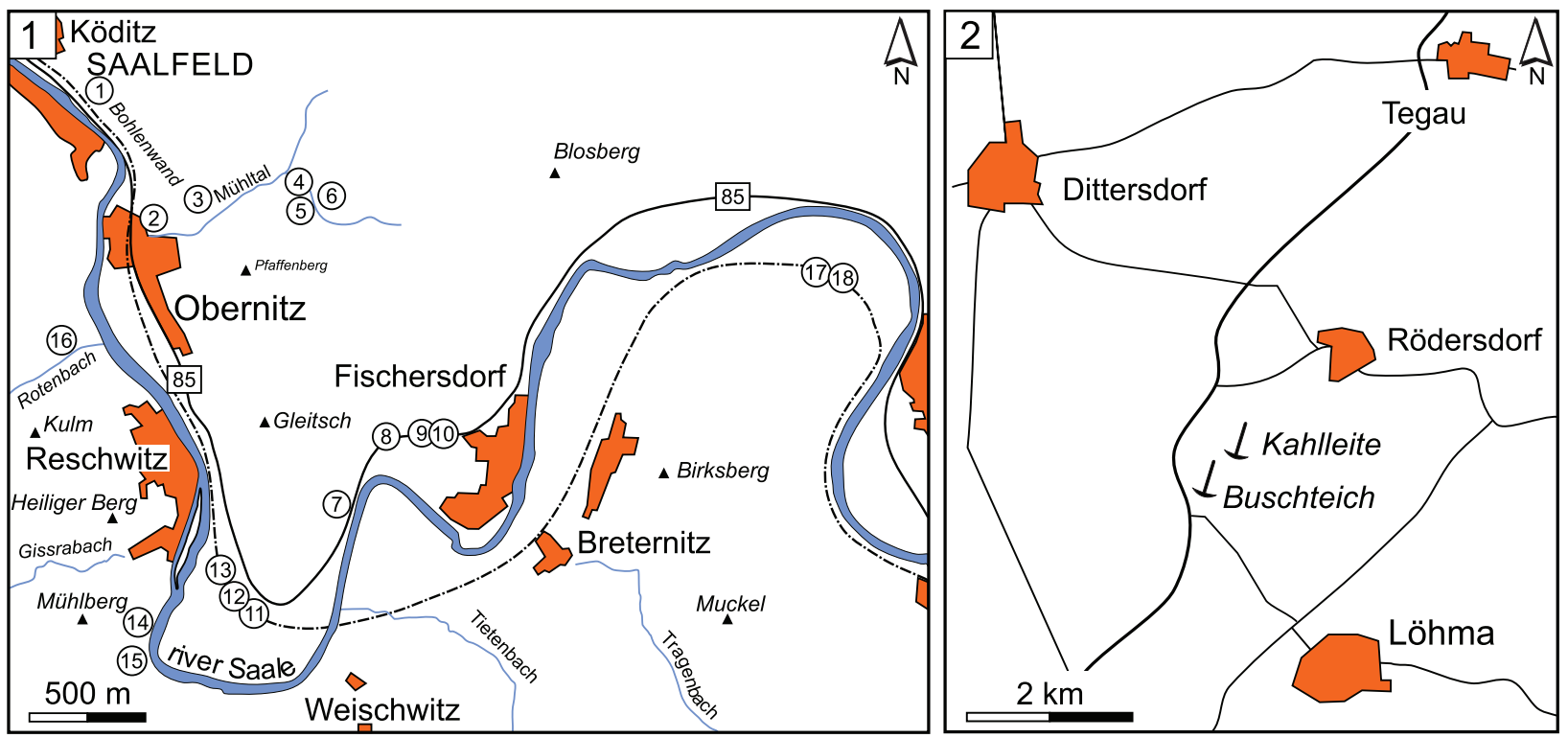

FIGURE 2. Topographic maps of Thuringian localities with fossiliferous top Famennian and/or basal Tournaisian sections. 1, southeastern environments of Saalfeld, localities 1-18 (compare Table 1) (modified from Bartzsch and Weyer, 2012). 2, Buschteich and Kahlleite sections SSW of Tegau (NNE of Schleiz).

published in 1848 and 1856 by Reinhard Richter (1813-1884). They include 14 "Upper Devonian" species of Brachiopoda (determined after Münster 1840 , or in open nomenclature; only one newly named: Terebratula silicula Richter, 1856, obviously from the Cheiloceras-"Stufe", PlattenbruchMember of Bohlen Formation). After death, his collection was acquired by the former Prussian Geological Survey in Berlin (now Berlin department of the Bundesanstalt für Geologie und Rohstoffe, Hannover) - the figured specimens escaped the destruction of the war years 1943-1945, but all supplementary materials were lost after a bombing attack destroying the complete regional Devonian collections of the Harz, Thuringian and Lower Silesian Mountains. More precise age data for the unzoned "Upper Devonian" of Richter $(1848,1856)$ are generally possible, due to his own stratigraphic notes of 1848 (p. 3, plate 1: bed " $g$ " = Breternitz Member of the Gleitsch Formation; Figure 3), due to the later revisions of Schmidt (1923), Schindewolf $(1924,1952)$, Pfeiffer (1954) and the wellstratified rich new macro- and micro-faunal collections of Bartzsch and Weyer during the years 1963-1992, partly published (Bartzsch and Weyer, 1982, 2012).

The "Upper Devonian" of the nineteeth century up to Schindewolf [1923, after the proposal of a still upper Devonian Gattendorfia-"Stufe" in Schindewolf (1920)] included all the cephalopod limestones below the drastic change towards the siliciclastic Culm facies (Liegende Alaunschiefer, now sensu Korn (2006), Kahlenberg-Subformation in the Rhenish Mountains, Rußschiefer Formatio) in Thuringia; Figure 3). This changed with Schmidt (1924) who elaborated the Carboniferous faunal characters of the Hangenberg Limestone = Gattendorfia-"Stufe"). His new system boundary then became a standard, especially after applying the decision of the second Heerlen Carboniferous Congress in 1935 (Paeckelmann and Schindewolf, 1937), where the Oberrödinghausen sequence (Hönnetal railway cut) was accepted as an international reference section.

Richter and Richter (1951), Schindewolf (1952) and Pfeiffer (1954) affirmed the presence of Lower Tournaisian equivalents of the Rhenish Hangenberg Limestone in Thuringia (now the Pfaffenberg Member of the Gleitsch Formation; Figure 3). Several fossils in Richter $(1848,1856)$, listed in Bartzsch and Weyer (1982, p. 4), come from Lower Hastarian beds, notably Delthyris sp. (1848, p. 45, plate 6 , figure 210) (= Crassumbo germanicus sp. nov.), Leptaena? sp. (1856, p. 130, plate 2, figures 76-79) (= Productina saalfeldensis sp. nov.). The presence of Lower Hastarian beds was proved also for the Upper Franconian locality Schübelhammer after a revision of the Rugosa coral Hebukophyllum priscum (Münster, 1840) (Weyer, 1994, p. 187).

Further publications dealing with selected German Brachiopoda from the aphotic facies 


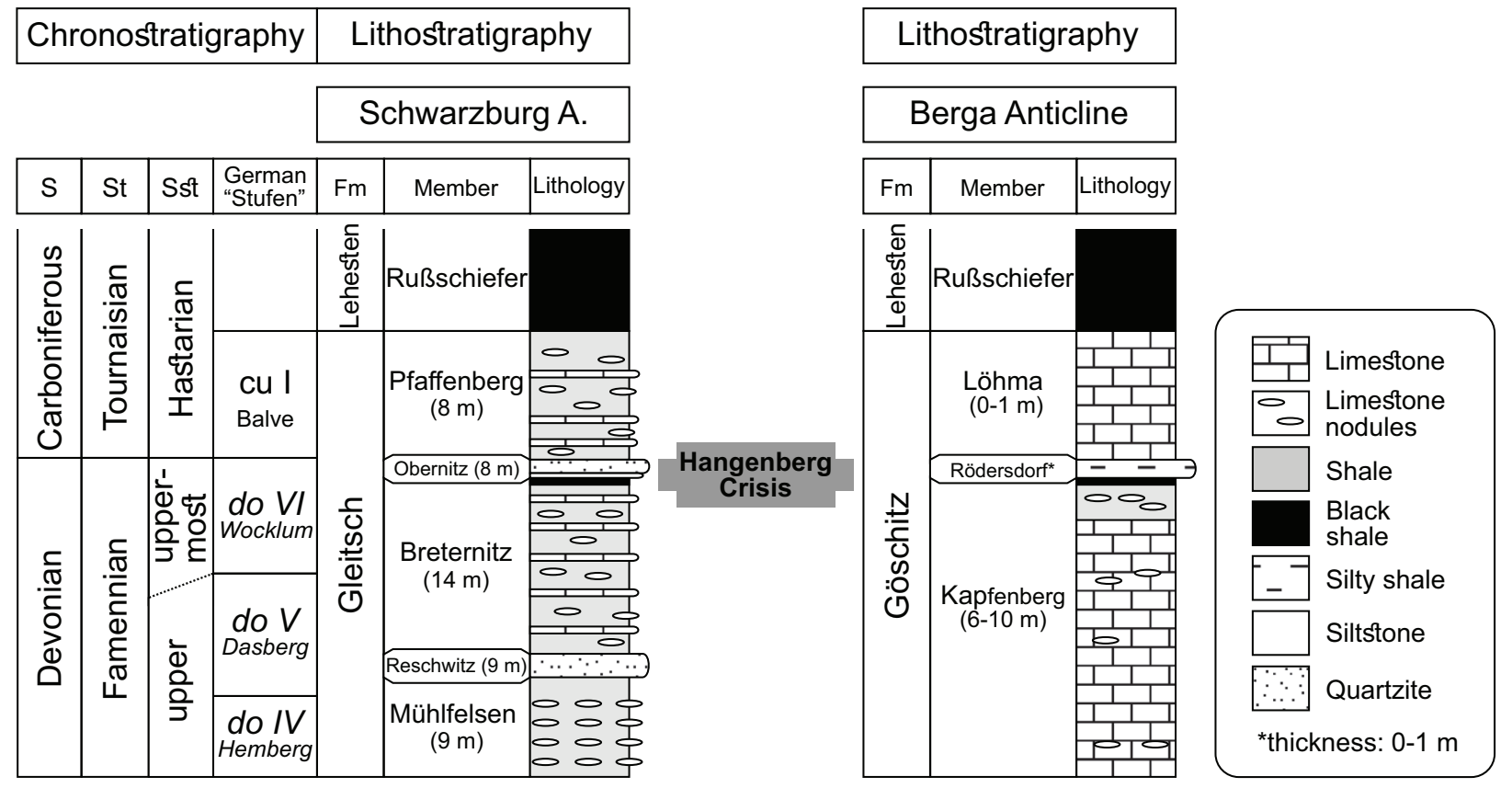

FIGURE 3. Upper Famennian and basal Tournaisian lithostratigraphy (with indication of thickness for each member) in the Thuringian Slate Mountains (modified from Bartzsch et al., 1999, 2001, 2008). A., Anticline; Fm, Formation; S, system; St, stage; Sst, substage.

around the Devonian-Carboniferous boundary are Tietze (1870), Paeckelmann (1913, 1930, 1931), Schmidt (1924), Grüneberg (1925), Gallwitz (1932), Weyer (1972, 1979), Bartzsch and Weyer (1986), Becker (1988, 1996), Bartzsch et al. (1998), Sartenaer (1997), Afanasjeva (2002) and Müller (2004). Comparatively few similar studies about such rare aphotic Famennian-Hastarian Brachiopoda were published in other countries: Poland (Biernat, 1983, 1988; Biernat and Racki, 1986a, 1986b; Sartenaer, 1998a; Halamski and Baliński, 2009), Czech Republic (Havlíček, 1979), Russia (Rozman, 1962), Algeria (Mottequin et al., 2015a), Morocco (Sartenaer, 1998a, 1998b, 1999, 2000) and China (Sartenaer and Xu, 1990).

In this paper, we studied new and well-dated collections from Saalfeld (Breternitz and Pfaffenberg members of the Gleitsch Formation; Figure 3) and other localities in Thuringia - more than 2000 specimens - represent the worldwide richest brachiopod assemblages of the aphotic cephalopod facies around the Devonian-Carboniferous boundary.

Based on material patiently collected between 1963-1992 by two of the authors (KB and DW), the goals of the present study are (1) to describe the upper and uppermost Famennian and the lower Tournaisian (Hastarian) brachiopod faunas from the Saalfeld area (Thuringia), (2) to discuss their palaeoecology and (3) to specify the conse- quences of the Hangenberg Crisis (Kaiser et al., 2011, 2016) on these benthic suspension-feeders in this region.

\section{GEOLOGICAL SETTING}

\section{Devonian-Carboniferous Boundary Beds of Thuringian Localities}

Such fossiliferous strata occur as suitable outcrops only in very few places of SE Thuringia (Figure 1). Two of them are stable small ancient quarries, accessible since more than 90 years. Two others disappeared, but their collections are still available. One group of localities - the best - is situated around the Bohlen southeast of Saalfeld, at the NE end of the SE flank of the Schwarzburg Anticline (Figures 1, 2.1), Western Thuringian Slate Mountains ("Schiefergebirge") and presents the more basinal facies of "cypridinic" (entomozoid) shales with nodular limestone layers. Three other localities - at the NW flank of the Berga Anticline (Figures 1, 2.2), Eastern Thuringian Slate Mountains - represent the shallower facies of cephalopod limestone.

Figure 3 illustrates the current local lithostratigraphy, as proposed by Bartzsch et al. (1999, 2001, 2008). This scheme replaced older names from the Saalfeld region, long time in use since Liebe and Zimmermann (1888) and Zimmermann (1914) in the geological mapping period by the 
TABLE 1. Localities SE of Saalfeld (as numbered in Figure 2) exposing the Breternitz Member (B), Clymenia/Wocklumeria Genozone, and the Pfaffenberg Member $(\mathrm{P})$, Gattendorfia Genozone.

\begin{tabular}{clc|clcc}
\hline No. & \multicolumn{1}{c|}{ Locality } & Member & No. & \multicolumn{1}{c}{ Locality } & Member \\
\hline 1 & Obernitz, Bohlen-North (Vorderbohlen) & $\mathrm{B}$ & 10 & Fischersdorf-East & $\mathrm{B}, \mathrm{P}$ \\
2 & Obernitz, Schlosspark & $\mathrm{B}$ & 11 & railway cut Gleitsch-SE $(\mathrm{km} \mathrm{144,4-144,5)}$ & $\mathrm{B}$ \\
3 & Obernitz, Bohlen, southern slope (right & $\mathrm{P}$ & 12 & railway cut Gleitsch-SE $(\mathrm{km} \mathrm{144,43)}$ & $\mathrm{P}$ & \\
& bank of lower Mühltal) & & & & $\mathrm{B}$ \\
4 & Obernitz, Bornleite, left upper Mühltal & $\mathrm{B}$ & 13 & railway cut Gleitsch-NW $(\mathrm{km} \mathrm{144,23)}$ & $\mathrm{B}$ \\
5 & Obernitz, Pfaffenberg-SW & $\mathrm{P}$ & 14 & Reschwitz, Mühlfelsen-North & $\mathrm{B}$ \\
6 & Obernitz, Pfaffenberg-NE & $\mathrm{P}$ & 15 & Reschwitz, Mühlfelsen-South & $\mathrm{B}$ \\
7 & Fischersdorf, Gositzfelsen & $\mathrm{B}, \mathrm{P}$ & 16 & Reschwitz, road cut Hoher Schuss & $\mathrm{B}$ \\
8 & Fischersdorf-West & $\mathrm{B}, \mathrm{P}$ & 17 & Breternitz-West/Middle & $\mathrm{B}$ \\
9 & Fischersdorf-Middle & $\mathrm{B}$ & 18 & Breternitz-East & \\
\hline
\end{tabular}

Prussian Geological Survey, up to Meyer (1920) and Pfeiffer (1954), but no longer in accordance to rules and terminology of the International Stratigraphic Guide (Hedberg, 1976). The acronyms do IV to do VI refer to successive Famennian cephalopod zones (Wedekind, 1908) with 'do' meaning Upper Devonian.

Nearly all the brachiopods of this study come from the Saalfeld region. The few additional, often not well-preserved specimens from the other Thuringian localities are only a supplement to underline the regional distribution of such faunas, which we know also from small collections in the northern Rhenish Mountains (Sauerland). These additional, mostly identical materials, found in literature, in older museum stores and in the field, are already mentioned here sometimes, but will be described in a separate publication. Present isolated data in other countries (especially Poland, but also Czech Republic, Russia, Morocco) promise perspectives for future studies of such often neglected brachiopod assemblages in the aphotic cephalopod facies.

Bohlen area. Bohlen is the name of the steep wall at the western slope of the mount Roter Berg east of Saalfeld, eroded by the Saale river at its right bank (the term Bohlenwand is used in Figure 2.1). There and nearby in an area of 2-3 km exist many, mostly small outcrops (listed in Table 1 and indicated in Figure 2.1) of the Breternitz and Pfaffenberg Members, which yielded nearly all the brachiopods (Figures 4,5). Details of sequence, fossil content, biozones and age can be found in Bartzsch and Weyer $(1982,2012)$ and Kononova and Weyer (2013). Macrofossils are rather rare, and to collect them is very time-consuming. Besides Brachiopoda, there occur Ammonoidea, Trilobita, Bivalvia, Gastropoda, Crinoida and
Anthozoa. Microfaunas are rich in Ostracoda (Thuringian = psychrospheric ecotype and Entomozoidae), but poorer in Conodonta and Foraminifera; they also include a few Chondrichthyes.

Possible biozonation for the Breternitz Member is shown in Kononova and Weyer (2013, figure 7) (Figure 4). Ammonoids start in the Clymenia laevigata Zone (lower Clymenia-"Stufe") and finish with the Wocklumeria sphaeroides Zone (uppermost Wocklumeria-"Stufe") just before the global Hangenberg Crisis. Remarkably six zones of psychrosphaeric ostracods had been discriminated by Blumenstengel (1997) but up to now this potential was never verified in any other region. Some corrections are necessary for the conodont zonation of Kononova and Weyer (2013). There the species Bispathodus spinulicostatus (Branson, 1934) was neglected and included into Bispathodus ziegleri (Rhodes et al., 1969) (see revision in Hartenfels and Becker, 2016), but the earlier appearance of Bispathodus ultimus ultimus (Bischoff, 1957) already in the upper Clymenia-"Stufe" can be verified for bed 17.2. (illustrated in a forthcoming paper), thus disqualifying this subspecies as an index fossil of the Wocklumeria-"Stufe" or Strunian or Uppermost Famennian. The ammonoid and conodont zonation of the Pfaffenberg Member is shown in Figure 5 (based on Bartzsch and Weyer, 1982).

Besides the usual index fossils (ammonoids, conodonts), several accompanying groups have been studied, both from the top Famennian and the basal Tournaisian: anthozoans (Weyer, 1971, 1981b, 1984, 2006), ostracods (Richter, 1869; Blumenstengel, 1959, 1965, 1979; Gründel, 1962; Becker and Blumenstengel, 1995) and trilobites (Hahn et al., 1995; Gawlick, 1996, 1997; Crônier et al., 1999; Lerosey-Aubril, 2006). 

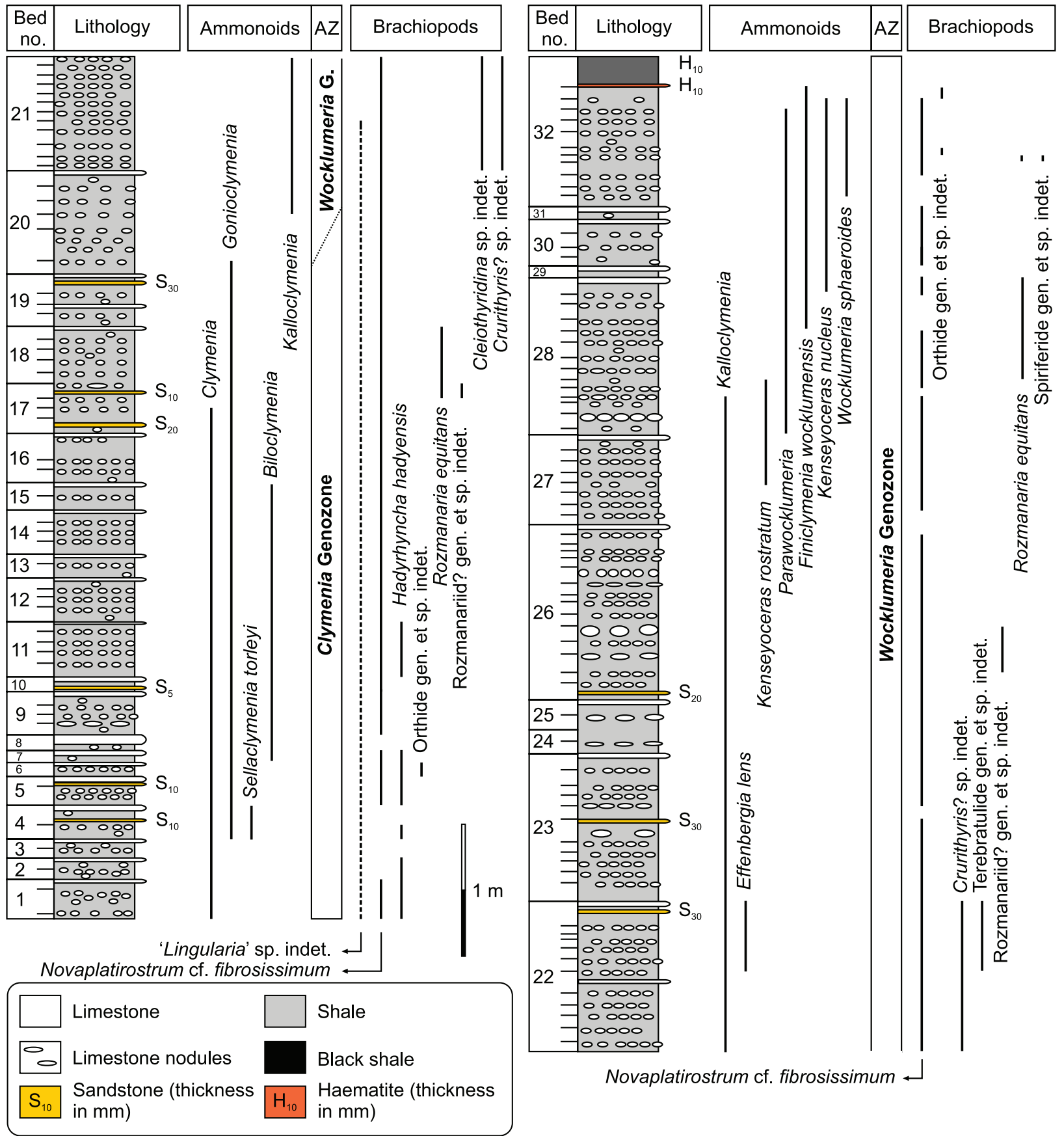

FIGURE 4. Lithostratigraphy and ammonoid zonation of the Breternitz Member near Saalfeld (Thuringia) and brachiopod distribution (modified from Bartzsch and Weyer, 2012).

Probestzella. This outcrop on the NE slope of the road Probstzella-Marktgölitz $(2.5 \mathrm{~km} \mathrm{NW}$ of the railway station Probstzella; Figure 1) offers a $16 \mathrm{~m}$ thick sequence of the nearly complete Breternitz Member (Bartzsch and Weyer, 2012, figure 8a-b); only the last metre is missing. The section demonstrated the quite perfect lithological uniformity of sedimentary cycles along the SE flank of the Schwarzburg Anticline but was unsuitable for col- lecting macrofossils. In 1991-1992 we found quite accidentally only one specimen of Novaplatirostrum.

Hirtenrangen in Steinach. A further, rather poor locality of the top Breternitz Member and the Pfaffenberg Member was studied by Gründel (1961, p. 71, figure 10), Hirtenrangen in the town of Steinach, near the southern end of the Schwarzburg Anticline [not represented in Figure 1; see 
PALAEO-ELECTRONICA.ORG

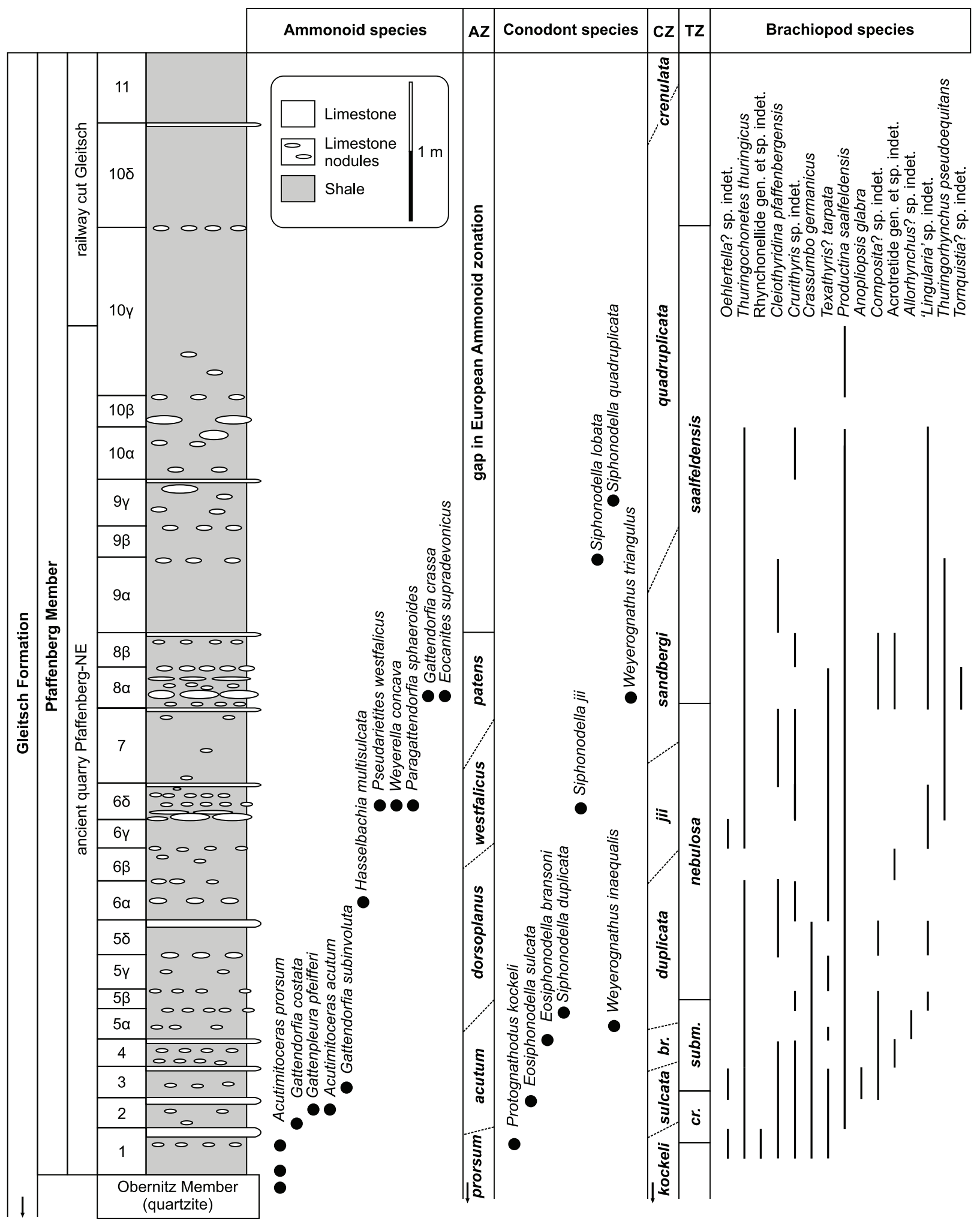

FIGURE 5 (caption on next page). 
localisation in Gründel (1961)]. The dominating shales yielded only determinable entomozoid ostracods (Gründel, 1961; Groos-Uffenorde, 1993). Conodonts and "silicified" (chloritisized) ostracods of the Thuringian ecotype could not be prepared, as the few limestone nodules are completely weathered. Gründel (1961, p.71, table 1) mentioned rare brachiopods; we suppose that these had been only undeterminable fragments.

Buschteich quarry. The ancient Buschteich quarry, abandoned long ago already at the end of the nineteenth century, is situated $1.5 \mathrm{~km} \mathrm{NE}$ of the village of Löhma (6 km NNE of the town of Schleiz) (Figures 1, 2.2), just east of the road SchleizAuma (part of the German South-North main road no. 2 München-Berlin). The name was derived from a nearby former pond "Großer Buschteich" (ca. $500 \mathrm{~m} \mathrm{SSW}$ just at the western side of the same road), which vanished around 1955 losing its water due to underground karst of Tertiary times. The locality lies on the SE flank of the Ziegenrück Syncline, immediate near the NW margin of the Berga Anticline (Figure 1), in a special Pörmitz Fold Zone (Gräbe, 1962). This small tectonic unit had suffered from strong compressions during the Variscan orogenesis in late Visean times, locally near to alpine nappe structures (Blumenstengel and Gräbe, 1969, figure 2).

The sequence includes the top of the volcanic Frasnian Göschwitz Formation, the extreme condensed Vogelsberg, Kahlleite and Göschitz Formations (cephalopod limestones), the Tournaisian Rußschiefer Formation, the lower Visean Buschteich Formation (Arundian "Kohlenkalk" = turbiditic calcarenites) and the basal Hasenthal Formation (sandy/silty shales). The section is illustrated in Bartzsch et al. (2008, figure 7). A detailed mea- surement and sampling (Bartzsch and Weyer during the year 1980) of the Kapfenberg Member (5.63 $\mathrm{m}$, from the annulata-Event to the equivalent of the Rhenish Hangenberg Black Shale) and the Löhma Member (0.55 m, Gattendorfia-"Stufe") remained unpublished, but was used in excursion guides (e.g., Bartzsch et al., 1993, p. 16). The complete Famennian and its conodont faunas were analyzed by Girard et al. (2016).

Special studies of the Devonian-Carboniferous boundary beds (Weyer, 1977, 1979, p. 100, plate 3; Bartzsch and Weyer, 1988, 1996, based on ammonoids and conodonts) recorded "Kenseyoceras" = Prionoceras n. sp. IV sensu Schindewolf $(1937)=$ Effenbergia lens (Korn, 1992) in the last $25 \mathrm{~cm}$ thick nodular limestone bed below the $15 \mathrm{~cm}$ shales of the Hangenberg Event. This index fossil of the upper Kalloclymenia subarmata Zone proves a remarkable gap (absence of the upper half of the Wocklumeria-"Stufe": Parawocklumeria paradoxa Zone). The younger Löhma Member starts also with a hiatus as the Acutimitoceras prorsum Zone (Stockum fauna) is missing. The oldest Carboniferous goniatites from the basal $10 \mathrm{~cm}$ are dated as Acutimitoceras acutum Zone within the Gattendorfia subinvoluta Zone: Gattendorfia costata Vöhringer, 1960, Gattenpleura bartzschi Weyer, 1976, Acutimitoceras acutum acutum (Schindewolf, 1923). The top $15 \mathrm{~cm}$ yielded Pseudarietites westfalicus Schmidt, 1924. Two conodonts determined as Siphonodella duplicata (Branson and Mehl, 1934) by Weyer (1977, plate 3, figures 8-9) now belong to Siphonodella duplicata morphotype 1 sensu Sandberg et al. (1978), renamed Siphonodella (Eosiphonodella) bransoni Ji, 1985.

Accompanying brachiopods are rare and not well preserved. Weyer (1979, plate 3) mentioned

FIGURE 5 (figure on previous page). Stratigraphy of the early Hastarian (Lower Tournaisian) Pfaffenberg Member near Saalfeld (Thuringia) - lithostratigraphy, ammonoid-conodont-trilobite biozones, brachiopod distribution. Lithological sequence (dominating shales with micritic limestone beds and nodules) after Bartzsch and Weyer (1982, figure 2, 2-3), mainly based on the type section in the ancient quarry Pfaffenberg-Northeast in the upper Mühltal valley near SaalfeldObernitz. Ammonoid and conodont biostratigraphy after Bartzsch and Weyer (1982), slightly modified according to current terminology and zoological nomenclature, including some new records. Trilobita zonation after Gawlick (1995, 1996, 1997, 2002), using the phylogeny of Liobolina Richter and Richter, 1951 in the European basinal facies - Liobolina (Guilinaspis) crestaverdensis Feist, 1992, Liobolina (Liobolina) submonstrans Richter and Richter, 1951, Liobolina (Liobolina) nebulosa Richter and Richter, 1951, and Liobolina (Liobolina) saalfeldensis Gawlick (in Hahn and Hahn, 2008). The black dot indicates the observed local first appearance of taxa, not necessarily the real first appearance in view of the rather rare ammonoid and conodont faunas. The hitherto mostly neglected remarkable gap in the ammonoid sequence and zonation of the German Gattendorfia-"Stufe" was already suspected in Bartzsch and Weyer (1982, figure 9) and is now reality (Korn and Weyer, 2003, p. 92, figure 12) - ammonoid faunas (with Kahlacanites) of this time interval occur in Morocco and Algeria (Ebbighausen et al., 2004; Bockwinkel and Ebbighausen, 2006). The range of the brachiopods Anopliopsis glabra and Thuringochonetes thuringicus is based on Afanasjeva (2002). Abbreviations: AZ, ammonoid zones; CZ, conodont zones; TZ, trilobite zones; br., bransoni Zone; cr., crestaverdensis Zone; subm., submonstrans Zone. 
Rozmanaria equitans (Schmidt, 1924) from the Wocklumeria-"Stufe". The few specimens from the Lower Hastarian are here determined for the first time.

Kahlleite quarry. This now abandoned quarry, 1 $\mathrm{km} \mathrm{SW}$ of village Rödersdorf (Figures 1, 2.2), in the Pörmitz Fold Zone is very near to the Buschteich quarry, but presented sections in a different, not so strongly condensed facies development, deposited originally in much greater distances. The once excellent sections were quarried away slowly and disappeared; the present eastern wall of the quarry stopped with the end of activities in tectonically stronger disturbed beds.

The $9.80 \mathrm{~m}$ thick upper Famennian Kapfenberg Member of the Göschitz Formation (Figure 3) is illustrated in Bartzsch et al. (2001 p. 108, 2008, p. 79) and in Gereke (2004, p. 10). It starts above the annulata Event (Wagnerbank with Prionoceras and Platyclymenia), reaches the Clymenia-"Stufe" [top of bed 22: Costaclymenia kiliani (Wedekind, 1914)] and the lower Wocklumeria-"Stufe" (bed 35: Kalloclymenia), and ends in the complete upper Wocklumeria-"Stufe"(beds 40-45: Kenseyoceras rostratum Selwood, 1960, Kenseyoceras nucleus (Schmidt, 1924), Finiclymenia wocklumensis (Lange, 1929), Wocklumeria denckmanni Wedekind, 1918) with the global Hangenberg Crisis (bed 46). Gereke (2004, figure 7) identified conodonts from the Late trachytera to the Middle praesulcata Zones.

The $1.80 \mathrm{~m}$ thick Löhma Member (Gattendorfia-"Stufe") (Figure 3) is illustrated in Bartzsch et al. (2001, p. 109, 2008, p. 80). The sometimes nodular cephalopod limestones yielded mainly ammonoid and conodont faunas. The oldest limestones (beds 1-3 in Bartzsch et al., 2001, 2008) represent the Acutimitoceras prorsum Zone and Protognathodus kockeli Zone, followed (in bed 4) by the Acutimitoceras acutum Zone and the Siphonodella (Eosiphonodella) sulcata Zone. The Pseudarietites westfalicus Zone is proved for beds 1923. Beds $24-27$ can be dated as Paragattendorfia patens Zone (using the graphic correlations of Korn and Weyer, 2003).

Very few brachiopods were collected and are here determined for the first time. They demonstrate only the extended regional distribution of the rich assemblage from Saalfeld at least in Germany. Geipel quarry. The quarry now disused is located on the western margin of Schleiz (Figure 1). The reported $4.40 \mathrm{~m}$ of dark-grey shales with limestone nodules at the bottom and margin of the entrance path nearly disappeared after gravelling with bro- ken stones. Schindewolf (1921, p. 173) listed an ammonoid fauna, erroneously dated as Gattendorfia-"Stufe", later revised as lower Wocklumeria"Stufe" (Schindewolf, 1937, p. 44). Richter and Richter (1926, p. 285) determined the trilobites of the Schindewolf collection. Records of Parawocklumeria and Glatziella glaucopis Renz, 1914 (Müller, 1956, p. 10; Weyer, 1981a, p. 3) indicate middle parts of the Wocklumeria-"Stufe" (Subzone of Kamptoclymenia endogona sensu Schindewolf, 1937). Without revision of the old ammonoid faunal lists it is impossible to prove the real presence of the Kalloclymenia subarmata Zone (perhaps its upper part: Effenbergia lens Zone). Illustrations of some selected faunal elements were only given in Weyer (1965, 1972, 1981a).

Rare brachiopod specimens occur: Rozmanaria equitans (Schmidt 1924) (Weyer 1972, plate 2, figure 5), rozmanariid? gen. et sp. indet. [here revised, for Rozmanaria equitans (Schmidt 1924) of Weyer, 1972, plate 2, figure 4], Novaplatirostrum cf. fibrosissimum (Tietze, 1870) [cited in Weyer (1981a, p. 5) as Planovatirostrum cf. richteri (Oppenheimer, 1916), here revised].

\section{MATERIAL AND METHODS}

The bulk of the material, collected by Bartzsch and Weyer between 1963-1992, is stored at the Museum für Naturkunde (Leibniz Institute) at the Humboldt-Universität in Berlin (MB.B.). Some older types (Richter, 1848, 1856; Schmidt, 1924) were borrowed from the Berlin Department of the Bundesanstalt für Geologie und Rohstoffe (Federal Institute for Geosciences and Natural Resources, Hannover), the former Prussian Geological Survey (BGR). Specimens curated at the Royal Belgian Institute of Natural Sciences (RBINS) collections, Brussels, are also illustrated.

Shells selected for scanning electron microscopy were observed using a low vacuum SEM, an ESEM FEI Quanta 200, but generally not coated with gold (except otherwise stated). Qualitative elemental composition of unidentified epizoans (see below) was determined through energy dispersive $X$-ray analysis (EDS) using the same SEM apparatus. The larger specimens were coated with ammonium chloride sublimate before being photographed.

\section{SYSTEMATIC PALAEONTOLOGY}

The supraspecific classifications follow Holmer and Popov (2000) for Class Lingulata, Rachebœuf $(2000,2007)$ for Suborder Chonetid- 
ina, Brunton et al. (2000) for Suborder Productidina, Williams and Harper (2000) for Order Orthida, Savage et al. (2002) and Savage (2007) for Order Rhynchonellida, Alvarez and Rong (2002) for Order Athyridida, Carter et al. (2006) for Order Spiriferida, and Lee et al. (2006) for Order Terebratulida. Grunt and Weyer (2016) recently discussed the authorship of the order Athyridida (Dagys, 1974 vs. Boucot et al., 1964) which was first introduced as such by Dagys (1974), but the latter did not attribute this authorship to himself but to Boucot et al. (1964). Grunt and Weyer's (2016) reassignment to Dagys (1974) should necessitate a revision of the super-levels of the classification, which is well beyond the scope of this paper.

Most of the synonymy lists refer only to the material from Thuringia. The representatives of the Suborder Chonetidina studied by Afanasjeva (2002) are only briefly discussed and not illustrated herein.

Phylum BRACHIOPODA Duméril, 1805

Subphylum LINGULIFORMEA Williams et al., 1996

Class LINGULATA Gorjansky and Popov, 1985

Order LINGULIDA Waagen, 1885

Superfamily LINGULOIDEA Menke, 1828

Family LINGULIDAE Menke, 1828

Genus LINGULARIA Biernat and Emig, 1993

Type species. Lingularia similis Biernat and Emig, 1993; from the Jurassic (Toarcian-Aalenian) of Spitsbergen.

"Lingularia"sp. indet.

Figure 4, Figure 5, Figure 6.1-6

Material. Breternitz Member: Obernitz-Vorderbohlen (do V): one undifferentiated valve; Gleitsch railway cut, section $A$, NE-side (bed 21.5): one undifferentiated valve. Pfaffenberg Member: Pfaffenberg-NE (beds: $5 \beta, 5 \delta, 6 \gamma-\delta, 8 \alpha-\beta, 9 \alpha-\gamma$ ): 24 undifferentiated valves.

Remarks. Due to their poor preservation, all the representatives of the family Lingulidae, both Famennian (Figure 6.1-4) and Tournaisian (Figure 6.5-6), are grouped under this unprecise identification. The available material is small-sized (up to 6 $\mathrm{mm}$ in length within the Breterniz Member vs. 4.5 $\mathrm{mm}$ within the Pfaffenberg Member). The lack of knowledge of the internal characters precludes a detailed identification and comparison with previously described species.

Numerous lingulid species were described in Mississippian and Pennsylvanian succession of Western Europe (see partial review in Graham, 1970). Among them, it appears that those from the
Tournaisian still remain poorly documented (e.g., Demanet, 1934; Winkler Prins and Martínez Chacón, 1999) contrary to their counterparts from the rest of the Carboniferous (e.g., Demanet in Renier et al., 1938; Dorsman, 1945; Vangerow, 1959; Graham, 1970). From the generic viewpoint, Biernat and Emig (1993) assigned several Carboniferous species such as Lingula mytiloides Sowerby, 1813 in 1812-1815 to their new genus Lingularia, which was recently revised by Bitner and Emig (2016). The latter erected the genus Eolingularia to include the Carboniferous species previously included in Lingularia, but Bitner and Emig (2016) failed to describe Carboniferous material to confirm the extension of Eolingularia and thus the presence of this genus in the Mississippian should still be demonstrated. Nevertheless, we refer temporarily the Thuringian material to "Lingularia" pending better material and a thorough revision of the internal morphology (generally unknown due to insufficient preservation) of the West European Mississippian and Pennsylvanian representatives of the Family Lingulidae. In order to facilitate such a revision, and although the goal of this paper is not the revision of the Tournaisian lingulids, it is helpful to re-illustrate the type material of "Lingularia" straeleni (Demanet, 1934) (Figure 6.7-22), which was originally described from the Tournaisian of southern Belgium. The exact age (Hastarian or Ivorian) of Demanet's species is currently not known with certainty due to discrepancies between the evasive labels accompanying the specimens and the data published in the literature (Demanet, 1934, 1958; Mortelmans, 1969). The specimens illustrated by Demanet (1934) were considered by him as paratypes and he did not select a holotype. For nomenclatorial purposes, the specimen RBINS a5802 (Demanet, 1934, plate 1, figure 5; Figure 6.14-17) is selected as the lectotype whereas the specimens RBINS a5801 (Demanet, 1934, plate 1, figure 4; Figure 6.7-13) and a5803 (Demanet, 1934, text-figure 1; Figure 6.18-22) are paralectotypes. Graham (1970) reported Demanet's species in the Visean-Bashkirian succession of Scotland, but it is not certain that the Scottish material is conspecific with the former species. Note that the species from Tournai was considered as a synonym (Vangerow, 1959) or a probable one (Biernat and Emig, 1993) of "Lingularia" mytiloides, but the internal morphology of the Tournaisian species remains unknown.

Occurrence. Gleitsch Formation, Breternitz (do V and do VI) and Pfaffenberg members (Figures 4, $5)$. 


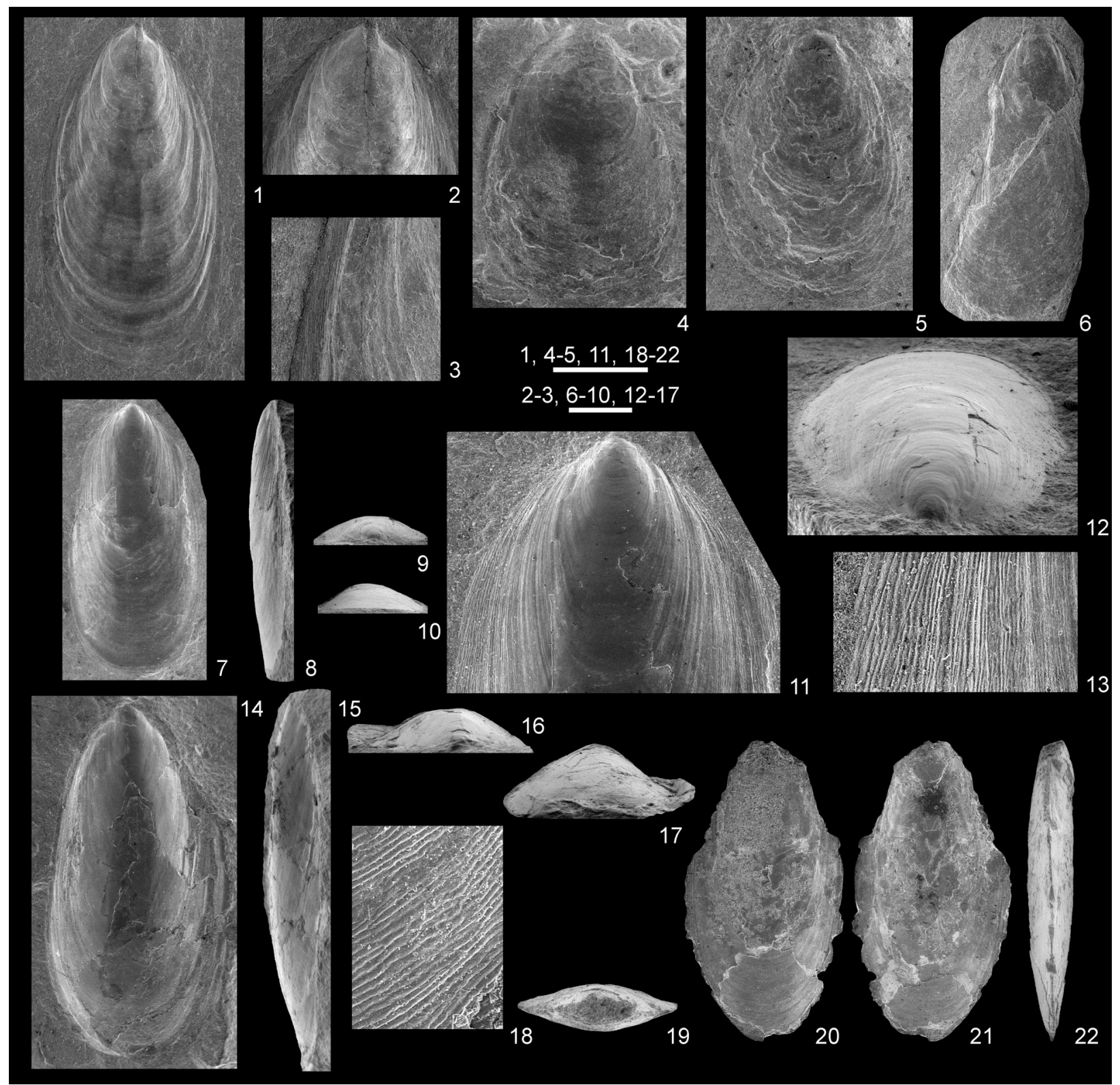

FIGURE 6. 1-4, "Lingularia” sp. indet. from the Breternitz Member. 1-3, possible ventral valve (MB.B.9817) in orthogonal view and details of the posterior region and of the ornamentation (Obernitz-Vorderbohlen, do V). 4, undifferentiated valve (MB.B.9818) in orthogonal view (railway cut Gleitsch-A-NE, bed 21.5, lower do VI). 5-6, "Lingularia" sp. indet. from the Pfaffenberg Member (Pfaffenberg-NE). 5, undifferentiated valve (MB.B.9819) in orthogonal view (bed $8 \beta$ ). 6, undifferentiated valve (MB.B.9820) in orthogonal view (bed 6 y). 7-22, "Lingularia" straeleni Demanet, 1934, Tournaisian (precise stratigraphic level unknown) from the Tournai region, southern Belgium. 7-13, undifferentiated valve (RBINS a5801) in in orthogonal, lateral, posterior, and anterior views, detail of the posterior region, oblique posterior view, and details of the ornamentation (precise origin unknown). 14-17, flattened, undifferentiated valve (lectotype, RBINS a5802) in orthogonal, lateral, posterior, and anterior views (precise origin unknown). 18-22, articulated specimen (RBINS a5803), almost complete, detail of ornamentation and posterior, "ventral", "dorsal" and lateral views (Antoing, Orient quarry). Scale bars: 1, 5-6, 11-12 (1 mm), 2 (400 $\mu \mathrm{m}), 3$ and $18(200 \mu \mathrm{m}), 4,7-10,14-17$ and 19-22 (2 mm), $13(250 \mu \mathrm{m})$. All SEM. 


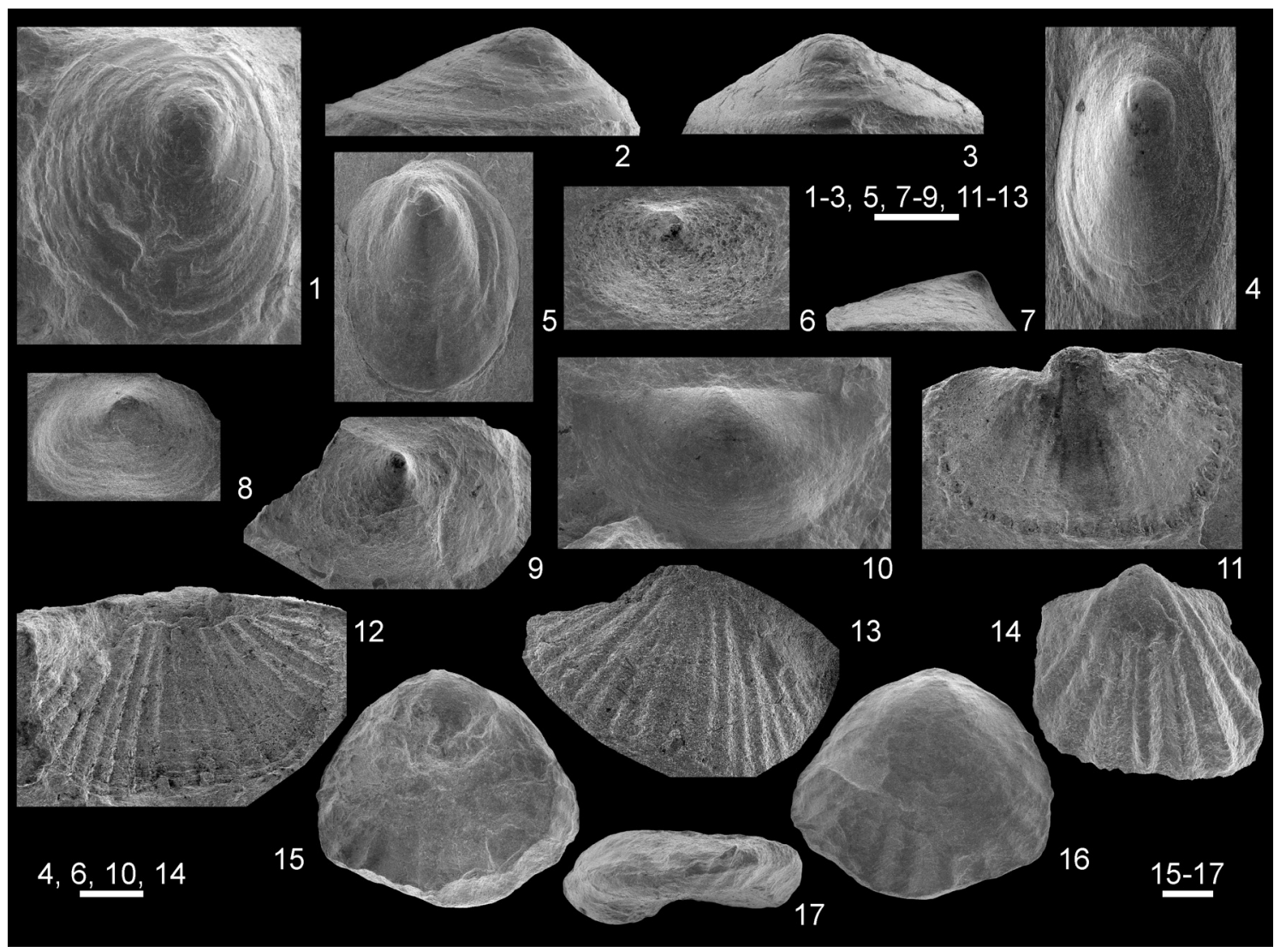

FIGURE 7. 1-5, Oehlertella? sp. from the Pfaffenberg Member (Pfaffenberg-NE). 1-3, almost complete dorsal valve (MB.B.9821) in dorsal, lateral and posterior views (bed 3). 4, complete dorsal valve (MB.B.9822) (bed 6y). 5, almost complete dorsal valve (MB.B.9823) (bed 6y). 6-9, Acrotretide? gen. et sp. indet. from the Pfaffenberg Member (Pfaffenberg-NE and SW). 6, decorticated ventral (?) valve (MB.B.9824) (bed 8ß NE). 7, ventral (?) valve (MB.B.9825) (bed 4 SW). 8-9, ventral (?) valve (MB.B.9826) in lateral and ventral views (bed 8a NE). 10, Tornquistia?

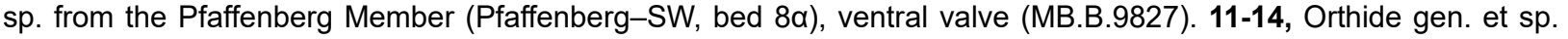
indet. from the Breternitz Member. 11-13, internal mould of a ventral valve (MB.B.9828), external mould and plasticine mould (Fischersdorf-Gositzfelsen, bed 6). 14, ventral valve (MB.B.9829) (Fischersdorf-West, bed 32.11). 15-17, Rhynchonellide gen. et sp. indet. from the Pfaffenberg Member (Pfaffenberg-NE, bed 1) crushed articulated specimen (MB.B.9830) in ventral, dorsal and lateral views. Scale bars: $1 \mathrm{~mm}$, except 4 and 14 (500 $\mu \mathrm{m})$. All SEM.

\section{Superfamily DISCINOIDEA Gray, 1840} Family DISCINIDAE Gray, 1840

Genus OEHLERTELLA Hall and Clarke, 1890

Type species. Discina pleurites Meek, 1875; from the Cuyahoga Formation, Tournaisian, Ohio, USA.

Oehlertella? sp. indet.

Figure 5, Figure 7.1-5

Material. Pfaffenberg-NE (beds 1, 3, 6y): three dorsal valves, including two juveniles.

Remarks. These poorly preserved dorsal valves are small-sized (up to ca. $3 \mathrm{~mm}$ in width), convex, subcircular to elliptic in outline, with their apex located in the posterior third of the valve. The relatively submarginal position of the apex suggests a tentative assignment to Oehlertella Hall and Clarke (1890) rather than to Orbiculoidea d'Orbigny, 1847 in which the dorsal apex is located subcentrally according to Mergl (2006). Of course, ventral valves are required to reach a more confident identification.

Occurrence. Gleitsch Formation, Pfaffenberg Member (sulcata-jii conodont zones) (Figure 5).

Order ACROTRETIDA Kuhn, 1949

Acrotretide? gen. et sp. indet.

Figure 5, Figure 7.6-9

Material. Pfaffenberg-NE (beds $6 \beta$, 8a- $\beta$ ): three (ventral?) valves; Pfaffenberg-SW (bed 4): one (ventral?) valve. 
Remarks. These poorly preserved, small (ventral?) valves (up to $4.9 \mathrm{~mm}$ in width) are subconical and characterized by a transversely oval outline with a straight and wide posterior margin and procline pseudointerarea. The ornamentation consists of poorly preserved growth lines. Their morphology is a reminiscent of that of representatives of some acrotretide genera. According to Holmer and Popov (2000), the Order Acrotetida is known with certainty until the Middle Devonian. Additional material is required to reach a better identification.

Occurrence. Gleitsch Formation, Pfaffenberg Member (jii-sandbergi conodont zones) (Figure 5).

Subphylum RHYNCHONELLIFORMEA Williams et al., 1996

Class STROPHOMENATA Williams et al., 1996

Order PRODUCTIDA Sarycheva and Sokolskaya, 1959

Suborder CHONETIDINA Muir-Wood, 1955

Superfamily CHONETOIDEA Bronn, 1862

Family ANOPLIIDAE Muir-Wood, 1962

Subfamily ANOPLIINAE Muir-Wood, 1962

Genus ANOPLIOPSIS Girty, 1938

Type species. Chonetina subcarinata Girty, 1926; from the Fort Payne Chert and Ridgetop Shale (Lower Mississippian) of western Tennessee, USA.

Anopliopsis glabra (Afanasjeva, 2002)

Figure 5

* 2002 Palaeoanopliopsis glabra sp. nov. Afanasjeva, p. 58, plate 4, figures 17-23.

2007 P. (= Palaeoanopliopsis) glabra; Rachebœuf, p. 2631.

Description. See Afanasjeva (2002).

Remarks. The genus Palaeoanopliopsis Afanasjeva, 2002 was considered as a junior subjective synonym of Anopliopsis Girty, 1938 by Rachebœuf (2007).

Occurrence. Gleitsch Formation, Pfaffenberg Member (sulcata conodont Zone) (Figure 5). The species is also reported in the Rhenish Slate Mountains (Afanasjeva, 2002).

\section{Genus TORNQUISTIA Paeckelmann, 1930}

Type species. Leptaena (Chonetes) polita M'Coy, 1852; from the Visean of Lowick, Northumberland, England.

Tornquistia? sp. indet.

Figure 5, Figure 7.10

Material. Pfaffenberg-SW (bed $8 \alpha$ ): one single ventral valve.

Remarks. This identification is made for a minute (ca. $5 \mathrm{~mm}$ in width), convex and transverse ventral valve, which is covered by numerous growth lines.
The right side of the hinge line displays a single orthomorph oblique $\left(80^{\circ}\right)$ spine whereas the left side shows a pit corresponding to the base of a spine. The external features such as the absence of radial ornamentation and the type of spine strongly suggest an assignment to Paeckelmann's genus, but the lack of data related to the internal morphology precludes a definitive generic identification.

Tornquistia was largely reported in the Carboniferous of Western Europe (e.g., Paeckelmann, 1930; Muir-Wood, 1962; Brand, 1970; Martínez Chacón, 1979), mostly in Visean-Serpukhvovian strata. Numerous Tornquistia species were described in the literature. According to Rachebœuf (in Wongwanich et al., 2004), most of them are still poorly known and a detailed revision of Girty's genus is urgently required.

Occurrence. Gleitsch Formation, Pfaffenberg Member (sandbergi conodont Zone) (Figure 5).

Family RUGOSOCHONETIDAE Muir-Wood, 1962 Subfamily RUGOSOCHONETINAE Muir-Wood, 1962

Genus THURINGOCHONETES Afanasjeva, 2002

Type species. Thuringochonetes thuringicus Afanasjeva, 2002; from the Gleitsch Formation (Pfaffenberg Member; Hastarian) of Thuringia, Germany.

Thuringochonetes thuringicus Afanasjeva, 2002 Figure 5

* 2002 Thuringochonetes thuringicus sp. nov. Afanasjeva, p. 60, plate 4, figures $1-9$.

2007 T. (= Thuringochonetes) thuringicus Afanasjeva, 2002; Rachebœuf, p. 2634, figure 1749,3 (= copy of Afanasjeva 2002).

Description. See Afanasjeva (2002).

Remarks. Rachebœuf (2007) transferred Afanasjeva's genus from the family Strophochonetidae to the family Rugosochonetidae.

Occurrence. Gleitsch Formation, Pfaffenberg Member (kockeli-quadruplicata conodont zones) (Figure 5). Afanasjeva (2002) also reported the species in the Hastarian of the Rhenish Slate Mountains.

Suborder PRODUCTIDINA Waagen, 1883 Superfamily PRODUCTOIDEA Gray, 1840 Family PRODUCTELLIDAE Schuchert, 1929 Subfamily PRODUCTININAE Muir-Wood and Cooper, 1960

Genus PRODUCTINA Sutton, 1938

Type species. Productus sampsoni Weller, 1909; from the Chouteau Limestone (Kinderhookian), Pettis County, Missouri. 
Productina saalfeldensis sp. nov. Figure 5, Figure 8

zoobank.org/CF516DFF-EE32-4937-A4AC-597C54D0BC24

1856 ?Leptaena spec.; Richter, p. 130, plate 2, figures 76-79.

p 1931 Productus (Thomasina) margaritaceus Phillips; Paeckelmann, p. 184, plate 17, figure 10 (only the specimen from AprikeRiemke).

1954 Productus sp.; Pfeiffer, p. 69.

v 1979 Productina sp.; Weyer, p. 100, plate 5, figure 17.

v 1982 Productina sp.; Bartzsch and Weyer, textfigure 11.1 , plate 6 , figures 9,10 (copy of Weyer, 1979).

v 1986 Productina sp.; Bartzsch and Weyer, plate 1 (right column), figure 2 .

v 1995 Productina sp.; Pfeiffer et al., plate 4.3.5-II, figure 17 (copy of Weyer, 1979).

v 2015 Productina sp.; Bartzsch et al., figure 14.2 (Brachiopoda) (copy of Bartzsch and Weyer, 1986).

Etymology. From the town of Saalfeld (Thuringia, Germany), which is close to the type locality.

Holotype. An articulated specimen (MB.B.9835), with dorsal valve partly concealed by shaly matrix (Figure 8.15-19) from the locality Pfaffenberg-SW (bed 5y) (Figures 2.1, 5).

Additional material. Fischersdorf-East (bed 7): five ventral valves; Fischersdorf-Gositzfelsen (bed 6ठ): two ventral valves; Pfaffenberg-NE (beds 2-4, $5 \alpha-\delta, 6 \alpha-\beta, 6 \delta, 7,8 \alpha-\beta, 9 \alpha-\gamma, 10 \alpha, 10 \gamma)$ : two articulated specimens, 284 ventral and eight dorsal valves, three ventral and three dorsal interiors; Pfaffenberg-SW (beds 2-4, $5 \alpha-\delta, 6 \alpha, 6 \gamma-\delta, 7,8 \alpha-\beta$, $9 \alpha-\gamma)$ : four articulated specimens, 404 ventral and three dorsal valves, 14 ventral and 16 dorsal interi- ors. Kahlleite quarry-E-1 (beds 7.1-2): two ventral and one dorsal valves.

Type locality. Pfaffenberg-SW (Figure 2.1). Type stratum. Gleitsch Formation, Pfaffenberg Member (Tournaisian, Hastarian) (Figures 3, 5).

Diagnosis. Shell small-sized (up to ca. $11.5 \mathrm{~mm}$ in width), strongly concavo-convex, semi-circular to semi-elliptic in outline with a strong ventral umbo, wider than long, widest slightly anteriorly to hinge line; anterior commissure rectimarginate to undulose (ventrally oriented); 6-10 regular, rounded ribs per $2 \mathrm{~mm}$ at front; spines posteriorly confined (one or two on both sides of the ventral umbo); growth lines irregularly spaced on ventral valve, more prominent (rugae) on dorsal valve (microlines observed); brachial ridges very low, lobate, anteriorly directed.

Description. Shell small-sized (up to ca. $11.5 \mathrm{~mm}$ in width), semi-circular to semi-elliptic in outline, wider than long, strongly concavo-convex, widest slightly anteriorly to hinge line; anterior commissure rectimarginate to undulose (ventraly oriented); ears inclined to become flat. Ventral valve regularly convex in posterior profile view as is the case in lateral one but with an accentuation in the posterior part; umbo large, markedly prominent; ginglymus not observed. Dorsal valve is markedly concave, with flattened posterolateral extremities (rarely observed), semi-circular to semi-elliptic in outline.

Shell covered by rounded ribs increasing by bifurcations and intercalations in ventral valve (610 ribs per $2 \mathrm{~mm}$ at front); spines posteriorly confined (one or two on both sides of the ventral umbo); growth lines irregularly spaced on ventral valve, more prominent (rugae) on dorsal valve (microlines observed).

Ventral interior (Figure 8.35-36) devoid of septum; endospines numerous; teeth not observed.

FIGURE 8 (on next page). Productina saalfeldensis sp. nov. from the Pfaffenberg Member (Pfaffenberg-NE and SW). 1-3, incomplete ventral valve (MB.B.9831) in ventral, lateral, and posterior views (bed $5 \alpha$ SW). 4-5, distorted ventral valve (MB.B.9832) in posterior and ventral views (bed $5 \beta$ SW). 6-8, ventral valve (MB.B.9833) in ventral, lateral and posterior views (bed 5y SW). 9-14, slightly distorted articulated specimen (MB.B.9834) in ventral, dorsal, oblique postero-dorsal, lateral, posterior and anterior views (bed $4 \mathrm{SW}$ ). 15-19, almost complete articulated specimen (holotype, MB.B.9835) with dorsal valve concealed with shaly matrix in ventral, dorsal, lateral, posterior and anterior views (bed $5 y$ SW). 20, incomplete dorsal external mould (MB.B.9836) (6ठ NE). 21-24, incomplete and slightly distorted ventral valve (MB.B.9837) in ventral, lateral, posterior and anterior views (bed 4SW). 25-27, almost complete ventral valve (MB.B.9838) in ventral, lateral and posterior views (bed 4 SW). 28-30, slightly distorted ventral valve (MB.B.9839) in ventral, lateral and posterior views (bed 4 SW). 31-34, ventral valve (MB.B.9840) with detail of lateral spine base, in ventral, lateral and posterior views (bed $5 \beta \mathrm{SW}$ ). 35-36, slightly distorted ventral internal mould (MB.B.9841) in ventral and oblique posterior views (bed $6 \delta \mathrm{NE}$ ). 37-38, distorted dorsal internal mould (MB.B.9842) in oblique posterior view and detail of the dorsal muscle field and of the poorly preserved cardinal process (bed $5 \alpha \mathrm{SW}$ ). 39, distorted dorsal internal mould (MB.B.9843) in dorsal view (bed 5a SW). 40-43, distorted dorsal internal mould (MB.B.9844) in dorsal, oblique lateral, and oblique posterior views and close-up of the posterior region (bed $5 \alpha \mathrm{SW}$ ). Scale bars: $2 \mathrm{~mm}$, except $31(200 \mu \mathrm{m}), 38(500 \mu \mathrm{m})$, and $43(1 \mathrm{~mm})$. All SEM. 


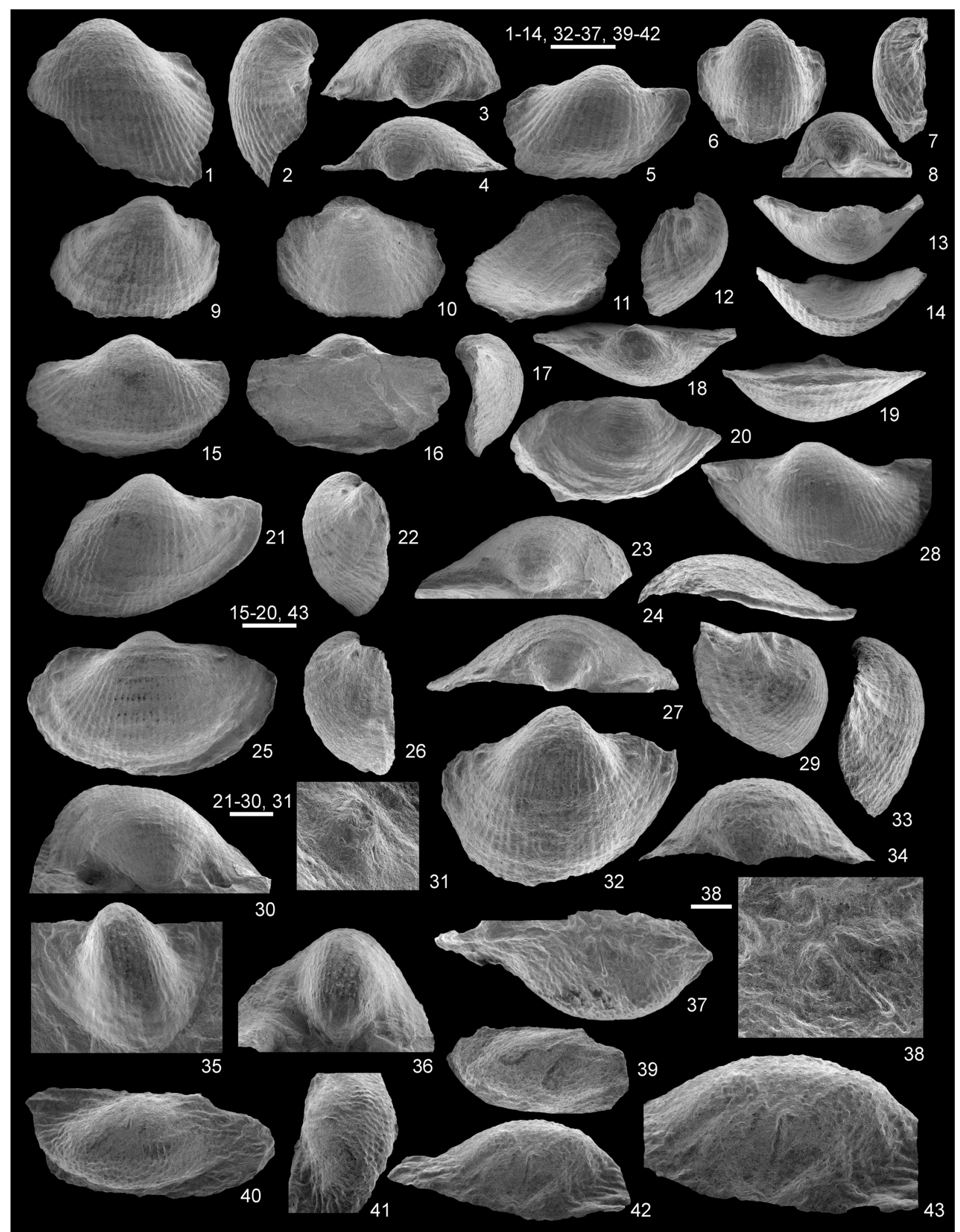

FIGURE 8 (caption on previous page). 
Dorsal interior (Figure 8.37-43) with adductor scars rounded trigonal in outline, slightly raised, small, smooth; median septum confined to the posterior half of the valve; endospines numerous; cardinal process bilobed anteriorly (observed only in a single specimen); brachial ridges very low, lobate, anteriorly directed.

Remarks. The discrimination criteria between the productinine genera Argentiproductus Cooper and Muir-Wood, 1951, Dorsirugatia Lazarev (in Lazarev and Suur'suren, 1992), and Productina Sutton, 1938, were exposed by Muir-Wood and Cooper (1960), Brunton and Mundy (1993) and Brunton et al. (2000). Based on their respective discussion, the Thuringian new species is assigned to Sutton's genus as it displays a regular, fine ribbing, which is not interrupted by concentric lamellae. However, most of the specimens are less inflated and more developed in width than the type species Productina sampsoni (Weller, 1909) and its closely related species $P$. parvula (Winchell, 1863), both from North America. Productina saalfeldensis sp. nov. seems to be closer to P. lodgepolensis Rodriguez and Gutschick, 1968 from Montana, in terms of size and shell thickness, but can be distinguished by its thinner ribbing and the development of faint brachial ridges. Productina saalfeldensis sp. nov. is similarly sized than $P$. globosa Roberts, 1963, but its ornamentation is thinner and its outline is more developed in width. The other Australian Productina species described by Roberts (1976), namely P. striata and P. morrisi (see also discussion in Brunton and Mundy, 1993) are clearly larger than the Thuringian one. Productina saalfeldensis sp. nov. cannot be confused with $P$. pectinoides (Phillips, 1836) due to its much smaller size and its more transverse outline. With Productus (Thomasina) decheni Paeckelmann, 1931, a possible upper Famennian, small-sized Productina representative according to Brunton and Mundy (1993) although its internal features are still unknown, $P$. saalfeldensis sp. nov. shares its transverse outline and its small size, but has a thinner ribbing, and its spines are confined to the posterior part of the ventral valve.

Occurrence. Gleitsch Formation, Pfaffenberg Member (sulcata-quadruplicata conodont zones) (Figure 5). Outside Thuringia, the species is also often recognized within the basal Hastarian Hangenberg Limestone in the Rhenish Slate Massif (see Paeckelmann, 1931, plate 17, figure 10; Bartzsch and Weyer, 1982, text-figure 11.1).

Class RHYNCHONELLATA Williams et al., 1996 Order ORTHIDA Schuchert and Cooper, 1932
Orthide gen. et $\mathrm{sp}$. indet.

Figure 4, Figure 7.11-14

? 1840 Orthis costata; Münster, p. 79, plate 14, figure 18.

v 1986 Hypsomyonia pauciplicata (Grüneberg, 1925); Bartzsch and Weyer, p. 149.

v 1998 Hypsomyonia pauciplicata (Grüneberg, 1925); Bartzsch et al., p. 45.

v 2008 Hypsomyonia; Bartzsch et al., p. 71.

Material. Fischersdorf-Gositzfelsen (bed 6): one ventral internal interior; Fischersdorf-West (beds $32.6,32.11$ ): one ventral valve, one dorsal valve, and one ventral interior.

Remarks. These minute (up to ca. $3.4 \mathrm{~mm}$ in width) strongly costellate shells display the following features (dorsal valve poorly preserved): rounded rectangular outline, convex ventral valve, flat dorsal valve, prominent ventral umbo, large ventral muscle field, small unsupported teeth, ca. 20 costae, numerous microlines irregularly thickened. The absence of dorsal interior, so important for generic identification of orthide genera, precludes a generic and specific identification, even if the external morphology suggests a parallel with the genus Hypsomyonia Cooper, 1955, known from the Frasnian of the USA (Cooper, 1955), Australia (Veevers, 1959) and maybe Belgium (Mottequin, 2008). According to Paeckelmann (1930, p. 156), the Upper Franconian (locality Schübelhammer) specimen with numerous ribs illustrated by Münster (1840, plate 14, figure 18) as "Orthis costata Sowerby in Murchison, 1839" would be identical to Dalmanella? pauciplicata Grüneberg, 1925. Grüneberg (1925) erected the species pauciplicata for minute brachiopods from the upper Famennian Cypridinenschiefer of Bergisches Land (locality Üllendahl) in Western Germany, that he considered as the same than Orthis n. sp. described by Paeckelmann (1913) from the same horizon but also from the lowest Etrœungt-Schiefer of the same area. Jux and Krath (1974) assigned Grüneberg's species to Hypsomyonia, in studying material from the lower Famennian of Bergisches Land, but without investigation of the internal features. The dorsal steinkern from the Dasberg"Stufe" (locality Diedenshausen) illustrated by Paeckelmann (1930, plate 9, figure 2) does not match that of typical Hypsomyonia representatives (compare with Cooper, 1955, plate 11, figures 6-11) as it lacks a long septum and a cruralium. The same remarks are also valid for the material from Western Germany illustrated by Gallwitz (1932) as Dalmanella? cf. pauciplicata. Furthermore, the upper Famennian material identified as $H$. pauciplicata 
from the Refrath 1 Borehole (Rhenish Massif) by Müller (2004) cannot be assigned to Hypsomyonia as the dorsal valve is also devoid of a cruralium supported on a high septum. In conclusion, Dalmanella? pauciplicata needs a revision urgently and additional material from Thuringia is needed to confirm (or otherwise) its conspecificity with Grüneberg's species.

Occurrence. Gleitsch Formation, Breternitz Member (Figure 4).

Order RHYNCHONELLIDA Kuhn, 1949

Rhynchonellide gen. et sp. indet.

Figure 5, Figure 7.15-17

Material. Pfaffenberg-NE (bed 1): two articulated specimens, one ventral valve and one dorsal valve; Pfaffenberg-SE (bed 1): one ventral valve.

Remarks. Due to their very poor state of preservation, these small-sized (ca. $6 \mathrm{~mm}$ in width) and ribbed rhynchonellides are left in open nomenclature. They are included here in order to provide the most complete survey of the brachiopod fauna.

Occurrence. Gleitsch Formation, Pfaffenberg Member (kockeli conodont Zone) (Figure 5).

\section{Superfamily PUGNACOIDEA Rzhonsnitskaya,} 1956

Family PUGNACIDAE Rzhonsnitskaya, 1956

Genus THURINGORHYNCHUS gen. nov. zoobank.org/2DF15CAB-70ED-43E8-B650-4C0FE7F2648E

Type species. Thuringorhynchus pseudoequitans gen. et sp. nov., by monotypy.

Etymology. In reference to Thuringia (Germany), where the type locality of its type species is located, and tó puyxos (Greek), beak.

Diagnosis. Shell small, sharply dorsibiconvex, wider than long, subcircular to transversally ovate in outline; anterior margin sharply emarginate; anterior commissure uniplicate; fold and sulcus originating at some distance from umbones; tongue very high, subrectangular, strongly bent dorsally; flanks smooth or exceptionally with few ribs; fold and sulcus generally smooth or more rarely with one or two low, rounded ribs in sulcus and two to three low ribs on fold only developed close to anterior margin; dental plates short; dorsal median septum short; septalium absent.

Remarks. Thuringorhynchus gen. nov. is included in the family Pugnacidae on the basis of the following features: high fold and tongue, few ribs, short dental plates and dorsal median septum, and absence of septalium. Thuringorhynchus gen. nov. displays strong external similarities (e.g., strongly dorsibiconvex lateral profile, markedly emarginate anterior margin, high tongue, strong fold and sul- cus) with the pugnacid genus Pammegetherhynchus Sartenaer, 1977 from the upper Frasnian of northern France and Poland (Sartenaer, 1977, 1997; Sartenaer et al., 1998), but differs by the presence of a short dorsal median septum. Thuringorhynchus gen. nov. is markedly different from the rozmanariid genus Rozmanaria Weyer, 1972 even if it superficially looks close to the latter (e.g., outline strongly emarginate, high fold and tongue). The markedly dorsibiconvex lateral profile (vs. strongly ventribiconvex lateral profile in Rozmanaria), the uniplicate anterior commissure (vs. unisulcate anterior commissure in Rozmanaria), the presence of dental plates and of a dorsal median septum in Thuringorhynchus gen. nov. allow an easy discrimination between both genera.

Thuringorhynchus pseudoequitans gen. et sp. nov. Figure 5, Figure 9, Figure 10, Figure 11, Table 2

zoobank.org/C6990A51-CACD-43C3-A30E-B3E321792977

v 1986 Rozmanaria equitans (Schmidt, 1924); Bartzsch and Weyer, plate 1 (right column), figure 1a-b.

v 2015 Rozmanaria? nov. sp.; Bartzsch et al., figure 14.1 (Brachiopoda) (copy of Bartzsch and Weyer, 1986).

Etymology. In reference to the confusion with the rhynchonellide species Rozmanaria equitans (Schmidt, 1924).

Holotype. An articulated specimen (MB.B.9852) (Figure 9.39-44), illustrated by Bartzsch and Weyer (1986, plate 1 (right column), figure $1 a-b)$, from the locality Pfaffenberg-NE (bed 8 $\beta$ ) (Figures 2.1,5).

Additional material. Pfaffenberg-NE (beds $6 \delta, 7$, $8 \alpha-\beta, 9 \alpha): 52$ articulated specimens, four ventral valves, two dorsal valves; Pfaffenberg-SW (bed $6 \delta)$ : two articulated specimens and one ventral valve.

Type locality. Pfaffenberg-NE (Figure 2.1).

Type stratum. Gleitsch Formation, Pfaffenberg Member (Tournaisian, Hastarian) (Figures 3, 5).

Diagnosis. As for genus.

Description. Shell small (up to $16.8 \mathrm{~mm}$ in width), sharply dorsibiconvex, wider than long, widest slightly anteriorly to mid-length, subcircular to transversally ovate in outline; anterior margin strongly emarginate; anterior commissure sharply uniplicate. Ventral valve gently inflated in both lateral and posterior profiles with anterolateral areas inclined to become flat; beak small, straight in juveniles to incurved in adults, close to dorsal umbo in adults but not in contact with it; foramen small, permesothyrid (only observed in one specimen, partly destroyed); palintropes small, curved; deltidial 


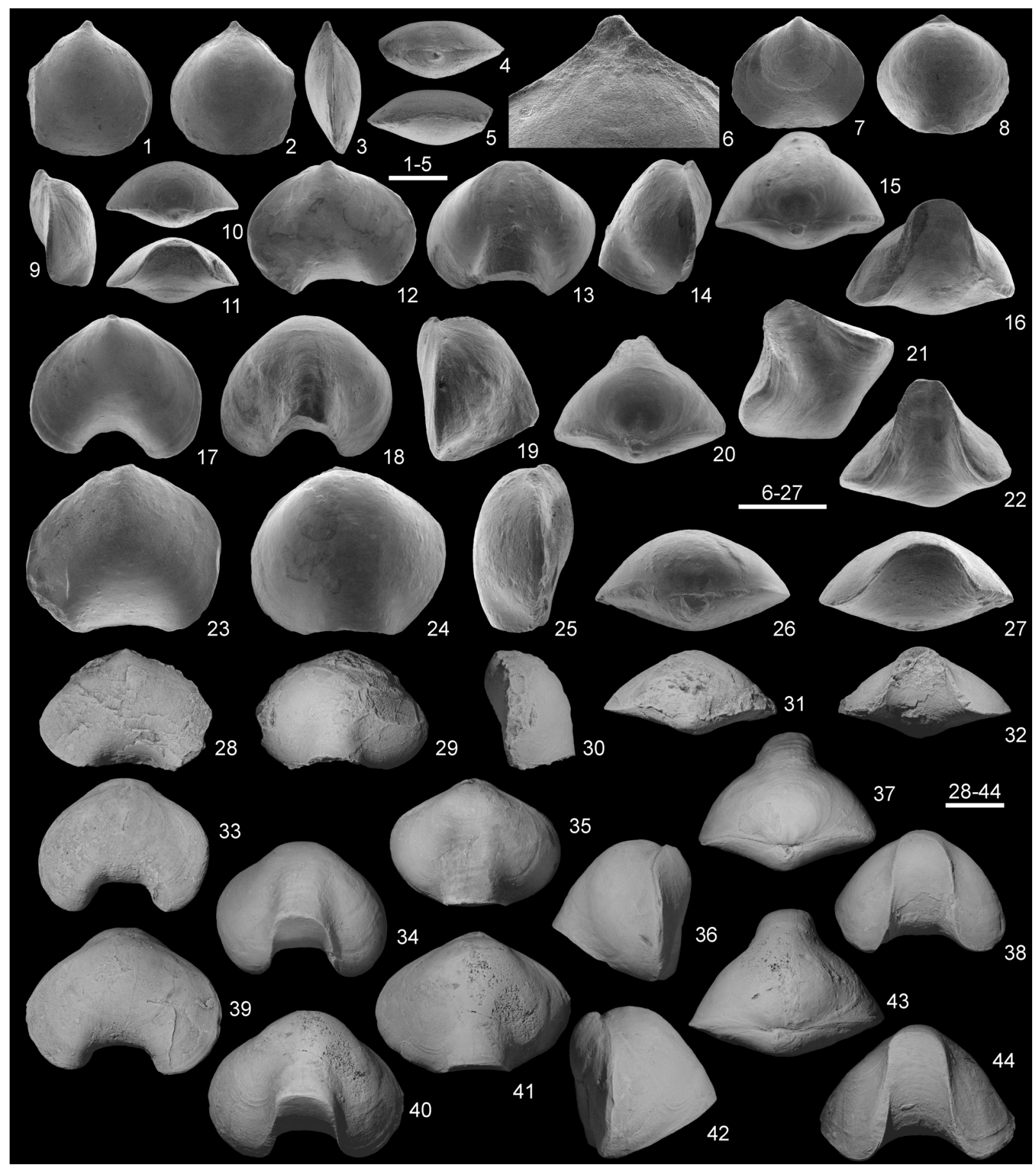

FIGURE 9. Thuringorhynchus pseudoequitans gen. nov. et sp. nov. from the Pfaffenberg Member (Pfaffenberg-NE). 1-6, juvenile articulated specimen (MB.B.9845), almost complete, in ventral, dorsal, lateral, posterior and anterior views, and detail of the posterior margin (bed 8ß). 7-11, juvenile articulated specimen (MB.B.9846) in ventral, dorsal, lateral, posterior and anterior views (bed 6ठ). 12-16, articulated specimen (MB.B.9847) in ventral, dorsal, lateral, posterior, oblique anterior and anterior views (bed 6ठ). 17-22, articulated specimen (MB.B.9848) in ventral, dorsal, lateral, posterior and anterior views (bed 6ठ). 23-27, articulated specimen (MB.B.9849) in ventral, dorsal, lateral, posterior and anterior views (bed 8a). 28-32, articulated specimen (MB.B.9850) in ventral, dorsal, lateral, posterior and anterior

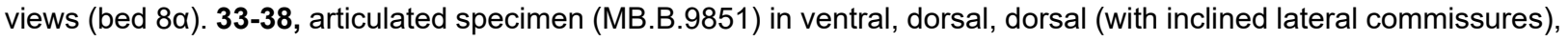
lateral, posterior and anterior (with inclined lateral commissures) views (bed 9a). 39-44a, articulated specimen (holotype, MB.B.9852) in ventral, dorsal, dorsal (with inclined lateral commissures), lateral, posterior and anterior (with inclined lateral commissures) views (bed $8 \beta)$. Scale bars: 1-5 $(2.5 \mathrm{~mm}), 6$ (1 mm), 7-44 (5 mm). All SEM, except 2844. 

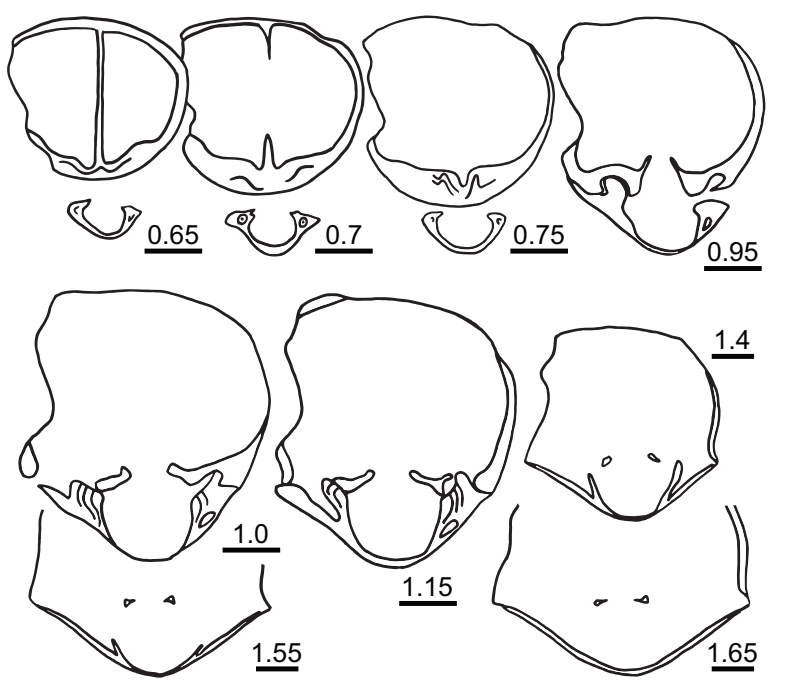

FIGURE 10. Transverse serial sections of Thuringorhynchus pseudoequitans gen. et sp. nov. from the Pfaffenberg Member (Pfaffenberg-NE, bed 8 $\alpha$ ) (MB.B.9853) Numbers refer to distances in $\mathrm{mm}$ from the tip of the ventral umbo. Scale bars: $1 \mathrm{~mm}$.

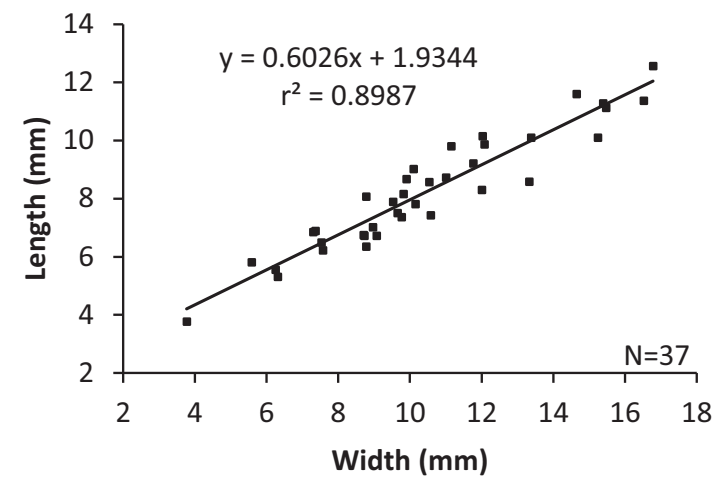

plates observed in transverse serial sections; sulcus wide, deep, inconspicuously originating at midvalve or more anteriorly, with blunt margins; flatbottomed at front but shallow in the distal part of the tongue; tongue very high, narrow subrectangular in outline, strongly bent dorsally. Dorsal valve sharply and regularly convex (leaving aside the fold) in posterior view, highest at front; fold inconspicuously originating at about mid-valve, with top slightly rounded at anterior margin.

Shell generally smooth, usually with no ribs developed on flanks (only a single specimen [1.7\%] displays two ribs on right ventral flank [none on the other flank] and one on the dorsal left flank); fold and sulcus generally smooth, but some specimens $(10.2 \%)$ display one or two low, rounded ribs in sulcus and two or three ribs on fold, developed close to anterior margin; growth lines numerous, sometimes thickened.

Ventral interior (Figure 10) with short dental plates diverging dorsally in transverse section and delimiting narrow lateral apical cavities; teeth small, relatively rounded in transverse section. Dorsal interior (Figure 10) with short and high
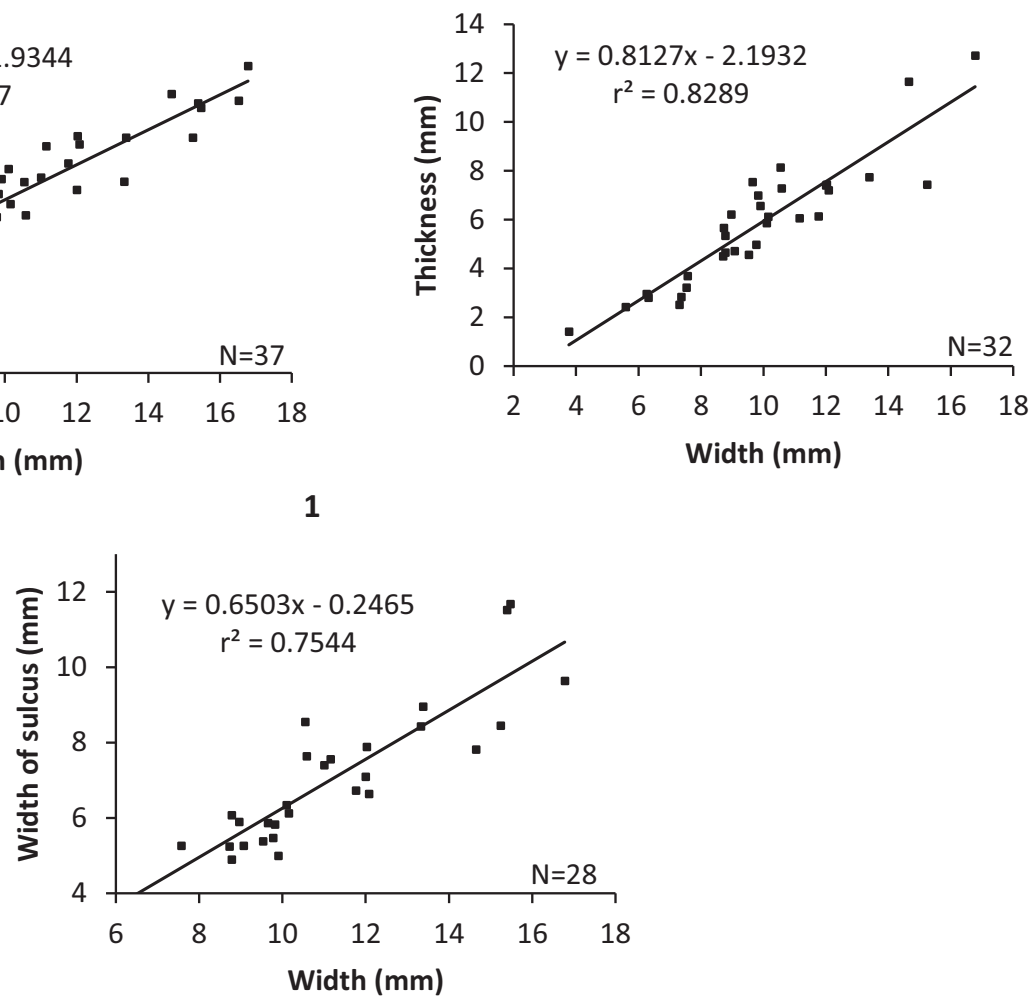

3

FIGURE 11. Scatter diagrams of Thuringorhynchus pseudoequitans gen. et sp. nov. Abbreviations: N, number of specimens measured; $r^{2}$ : coefficient of linear regression. 1, Relation between shell width and length. 2, Relation between shell width and thickness. 3, Relation between shell width and sulcus width. 
TABLE 2. Measurements in mm of Thuringorhynchus pseudoequitans gen. et sp. nov. Abbreviations: $L-$ length of the shell, $\mathrm{T}$ - thickness of the shell, $\mathrm{W}$ - width of the shell, Wi - width of the interarea, Ws - width of the sulcus.

\begin{tabular}{lccccccc}
\hline & W & L & T & Ws & L/W & T/W & Ws/W \\
\hline N & 37 & 37 & 32 & 28 & 37 & 32 & 28 \\
Mean value & 10.4 & 8.2 & 5.8 & 7.1 & 0.81 & 0.57 & 0.63 \\
Standard deviation & 3.1267 & 1.9875 & 2.5029 & 1.8289 & 0.0915 & 0.1228 & 0.0749 \\
Standard error & \pm 0.5140 & \pm 0.3267 & \pm 0.3505 & \pm 0.3456 & \pm 0.0150 & \pm 0.0217 & \pm 0.0141 \\
MIN & 3.8 & 3.8 & 1.4 & 4.9 & 0.64 & 0.34 & 0.51 \\
MAX & 16.8 & 12.6 & 12.7 & 11.7 & 1.04 & 0.80 & 0.81 \\
\hline
\end{tabular}

median septum; hinge plates divided with inner edges converging dorsally; dental sockets deep; crural bases stout (due to strong recrystallization, development of crura unknown).

Measurements. See Figure 11 and Table 2.

Remarks. Although both species look like similar superficially (e.g., shell usually smooth, anterior commissure strongly developed), Thuringorhynchus pseudoequitans gen. et sp. nov. cannot be confused with Rozmanaria equitans (Schmidt, 1924) (see above) notably due to its markedly different lateral profile (dorsibiconvex vs. ventribiconvex), its distinct anterior commissure (uniplicate vs. unisulcate) and the presence of dental plates in the former.

Occurrence. Gleitsch Formation, Pfaffenberg Member (jii-sandbergi conodont zones) (Figure 5). Outside Thuringia, some poorly preserved specimens were recovered from the Rhenish Slates Mountains (Hönnetal railway cut section near Oberrödinghausen, Hangenberg Limestone [Gattendorfia-"Stufe"], collections gathered by Schindewolf in 1935 and Weyer in 1993). These specimens are from beds 2, 3c1 and 3d1 sensu Korn and Weyer (2003, figure 5), thus from the Paprothites dorsoplanus, Pseudarietites westfalicus and Paragattendorfia patens ammonoid zones sensu Vöhringer (1960) or Upper Siphonodella duplicata (now Siphonodella jii) and lower Siphonodella sandbergi conodont zones sensu Sandberg et al. (1978).

\section{Family ROZMANARIIDAE Havlíček, 1982} Genus HADYRHYNCHA Havlíček, 1979

Type species. Hadyrhyncha hadyensis Havliček, 1979; from the upper Famennian Hády Limestone (“do V or do VI"), Moravia, Czech Republic.

Hadyrhyncha hadyensis Havlíček, 1979

Figure 4, Figure 12.1-25

* 1979 Hadyrhyncha hadyensis Havlíček, p. 99, text-figure 8, plate 2, figures 6-9. v 19861986 Hadyrhynchia (sic) hadyensis Havlíček, 1979; Bartzsch and Weyer, plate 1 (right column), figure 6.

1998b H. (= Hadyrhyncha) hadyensis; Sartenaer, p. 117.

v 2008 Hadyrhyncha; Bartzsch et al., p. 71.

v 2015 Hadyrhyncha hadyensis Havlíček, 1979; Bartzsch et al., figure 14.6 (Brachiopoda) (copy of Bartzsch and Weyer, 1986).

Material. Breternitz-Middle (beds 2.1-2, 5.2, 6, 11.1-5): five articulated specimens, one dorsal valve; Breternitz-West (bed 1.1-3): two articulated specimens; Fischersdorf-Gositzfelsen (beds 1.1-3, $6,7)$ : four articulated specimens, one ventral valve; Fischersdorf-Middle (beds 4.1, 5.1, 5.2): three articulated specimens, one ventral valve.

Description. Shell medium-sized (up to $18.3 \mathrm{~mm}$ in width), aequibiconvex to ventribiconvex, wider than long, widest at about mid-length, transversally elliptic in outline; anterior margin straight; anterior commissure unisulcate. Ventral valve regularly convex in posterior and lateral profile views, with flanks slopping gently towards lateral commissures; umbo relatively prominent; beak curved; fold inconspicuously originating near mid-valve or anteriorly to it, very low, flat-topped at front. Dorsal valve regularly convex in posterior and lateral profile views, with flanks slopping gently towards lateral commissures; sulcus inconspicuously originating near mid-valve, with blunt margins, wide, flat-bottomed at front; tongue semi-elliptic to subtrapezoidal in outline, low, generally not perpendicular to commissural plane.

Ornamentation of low, rounded costae (up to six in sulcus and eight on flanks), originating close to the umbones, frequently dividing both on flanks and in sulcus (intercalation not observed on fold, most probably due to deficient preservation); growth lamellae not preserved.

Ventral and dorsal interiors are not investigated. 


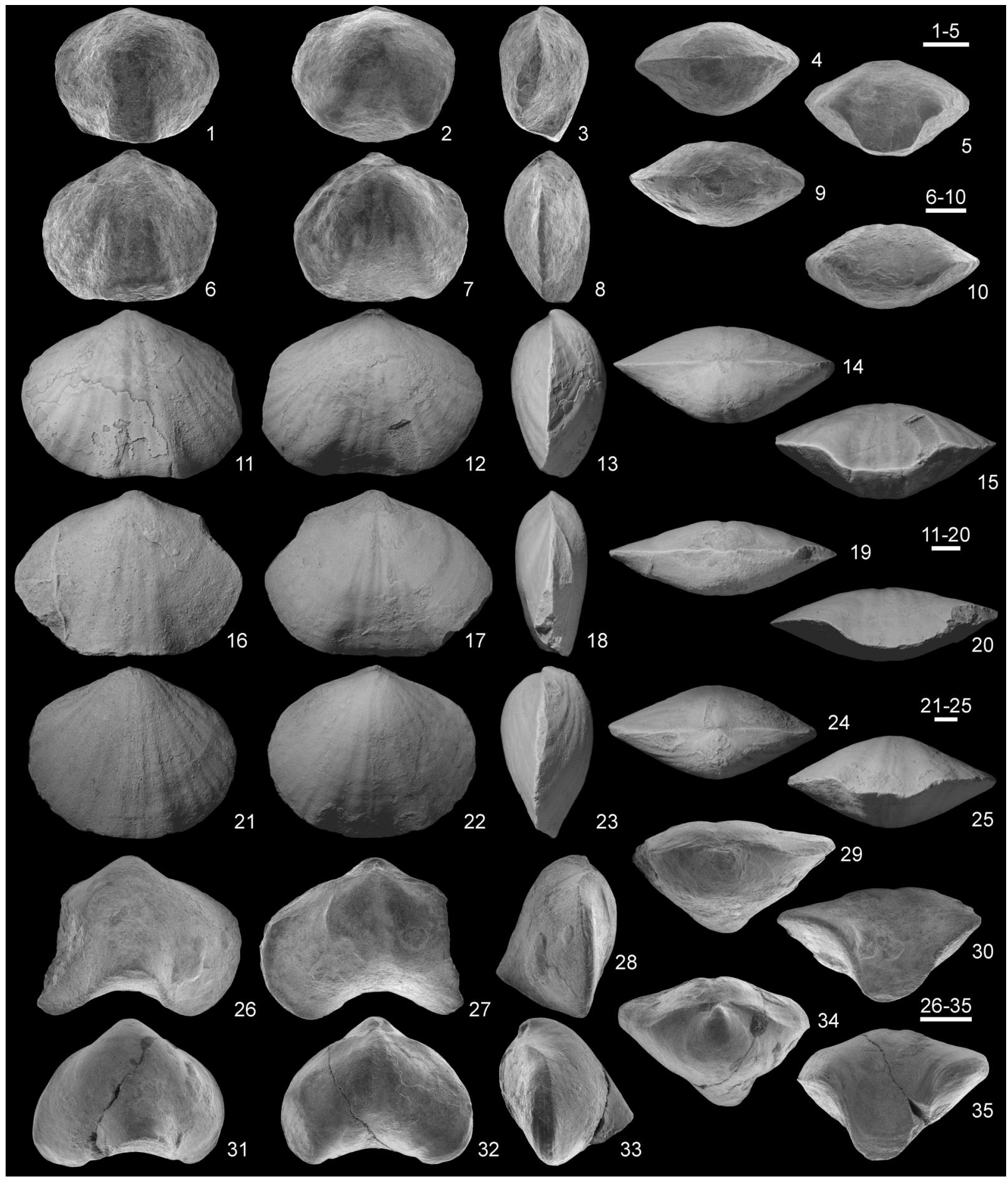

FIGURE 12. 1-25, Hadyrhyncha hadyensis Havlíček, 1979 from the Breternitz Member (do V). 1-5, juvenile articulated specimen (MB.B.9854) in ventral, dorsal, lateral, posterior and anterior views (Breternitz-Middle, bed 2.1-2). 6-10, juvenile articulated specimen (MB.B.9855) in ventral, dorsal, lateral, posterior and anterior views (Breternitz-Middle, bed 6). 11-15, articulated specimen (MB.B.9856) in ventral, dorsal, lateral, posterior and anterior views (FischersdorfMiddle, bed 5.1). 16-20, articulated specimen (MB.B.9857) in ventral, dorsal, lateral, posterior and anterior views (Fischersdorf-Middle, bed 4.1). 21-25, articulated specimen (MB.B.9858) in ventral, dorsal, lateral, posterior and anterior views (Breternitz-Middle, bed 11.1-5). 26-35, Rozmanaria equitans (Schmidt, 1924) from the Breternitz Member (do V). 26-30, incomplete articulated specimen (MB.B.9859) in ventral, dorsal, lateral, posterior and anterior views (Fischersdorf-Gositzfelsen, bed 18.1-5). 31-35, articulated specimen (MB.B.9860) in ventral, dorsal, lateral, posterior and anterior views (Mühlfelsen-North, bed 18.1-2). Scale bars: $2 \mathrm{~mm}$. All SEM, except 11-25. 
Remarks. The Thuringian material from the lower Clymenia-"Stufe" (Clymenia laevigata Zone), which was previously illustrated by Bartzsch and Weyer (1986), fits well the diagnosis of the Moravian species described by Havlíček (1979) in spite of its relatively poor preservation. In Europe, the genus Hadyrhyncha was reported by Halamski and Baliński (2009) in the uppermost Famennian (do $\mathrm{VI}$ ) of Poland, but this age determination is not sure, as the authors themselves (p. 290) admit that also ammonoids of the Clymenia-"Stufe" had been found in their "bed L". The records from Northern Africa are older: Mottequin et al. (2015a) (Algeria, boundary of Platyclymenia-/Clymenia-"Stufe"), Sartenaer (1998b) (Morocco, Clymenia-"Stufe"). The precise age of the Czech type materials from Moravia (Hady Limestone near Brno, "do V-VI") remains unclear without more accurate locality data, e.g., as used by Chlupáč (1966, tab. 2) during his trilobite studies; we need detailed recollecting, underlined by index fossils as ammonoids and/or conodonts.

Occurrence. Gleitsch Formation, Breternitz Member (Figure 4).

Genus NOVAPLATIROSTRUM Sartenaer, 1997

Type species. Novaplatirostrum sauerlandense Sartenaer, 1997, upper Famennian, northwestern Sauerland, Germany.

Novaplatirostrum cf. fibrosissimum (Tietze, 1870)

Figure 4, Figure 13.1-26, Figure 14, Table 3

1848 Terebratula [sp.]; Richter, p. 40, plate 5, figures 153-159.

1856 Terebratula subcurvata Münster var.; Richter, p. 115, plate 1, figures 37-39.

cf. ${ }^{*} 1870$ Atrypa (Spirigera?) fibrosissima nova species Tietze, p. 148 , plate 17 , figures 38 , 38a.

v 1979 Planovatirostrum fibrosissimum (Tietze, 1870); Weyer, plate 4, figure 14.

v 1979 Planovatirostrum cf. planoovale (Nalivkin, 1937); Weyer, p. 79, plate 4, figure 13.

v 1986 Planovatirostrum fibrosissimum (Tietze, 1870); Bartzsch and Weyer, plate 1, figure 5 (right column).

1997 Novaplatirostrum sp.; Sartenaer, p. 33-34, table 1, figure 2 (see this author for a detailed synonymy of the material from Thuringia).

v 1999 Novaplatirostrum; Bartzsch et al., p. 178.

2000 Planovatirostrum fibrosissimum (Tietze, 1870); Sartenaer, p. 76.

v 2015 Novaplatirostrum nov. sp.; Bartzsch et al., figure 14.4 (Brachiopoda) (copy of Bartzsch and Weyer, 1986). v 2015 Novaplatirostrum fibrosissimum (Tietze 1870); Bartzsch et al., figure 14.5 (Brachiopoda) (copy of Bartzsch and Weyer, 1986).

Material. Railway cut Gleitsch: 39 articulated specimens; Breternitz-East, Middle, and West: 155 articulated specimens; Fischersdorf-East and West: 45 articulated specimens; Geipel-Steinbruch in Schleiz: one articulated specimen; Fischersdorf-Gositzfelsen: 188 articulated specimens; Reschwitz-Hoher Schuss: one articulated specimen; Reschwitz-Mühlfelsen-North and South: 21 articulated specimens; Obernitz-Bornleite: 28 articulated specimens; Obernitz-Schlosspark: 11 articulated specimens; Obernitz-Vorderbohlen: 40 articulated specimens; Probstzella: one articulated specimen.

Description. Shell medium-sized (up to ca. 30.5 $\mathrm{mm}$ in width), flatly biconvex (valves subaequally thick), variable in outline (transverse-elliptical to subrounded), generally wider than long; hinge line short; anterior margin flat to rounded; anterior commissure uniplicate in adults (rectimarginate in juveniles), exceptionally slightly parasulcate, slightly (generally) to moderately serrate or only very slightly undulated by the median costae, if present. Ventral valve with small beak, erect to slightly incurved, overhanging the hinge line, often almost in contact with the dorsal umbonal region; palintropes low, concave, defined by sharp beak ridges; no deltidial plates seen; in juveniles, sulcus absent; in adults, sulcus only perceptible close to anterior margin, very shallow, wide, flat- to slightly roundbottomed at front or only indicated by the presence of median ribs; tongue wide, very low, trapezoidal in outline and sharp borders, sometimes non-existent. Dorsal valve with maximum height in posterior third of valve, then decreasing regularly towards anterior margin; in juveniles, fold absent; in adults, fold only developed close to anterior margin, very low, wide, flat-bottomed to slightly depressed.

General rib formula: 0 to 4/3 (median), 0 (parietal), 0 (lateral); median ribs restricted to anterior shell part, variably developed: simple, rounded to angular, low and well-marked or very low and moderately marked or poorly discernible or absent; parietal ribs absent; lateral ribs not frequent, being mere commissure undulations; capillae numerous (ca. 8 per $1 \mathrm{~mm}$ ) (Figure 12.1); growth lamellae irregularly spaced.

Internal morphology illustrated by Sartenaer (1997, figure 2). Ventral interior with small, wide, strong, and unsupported teeth. Dorsal interior with clearly distinct layer of secondary shell, resting on hinge plate; hinge plate divided; outer hinge plates flat to slightly concave; inner socket ridges moder- 


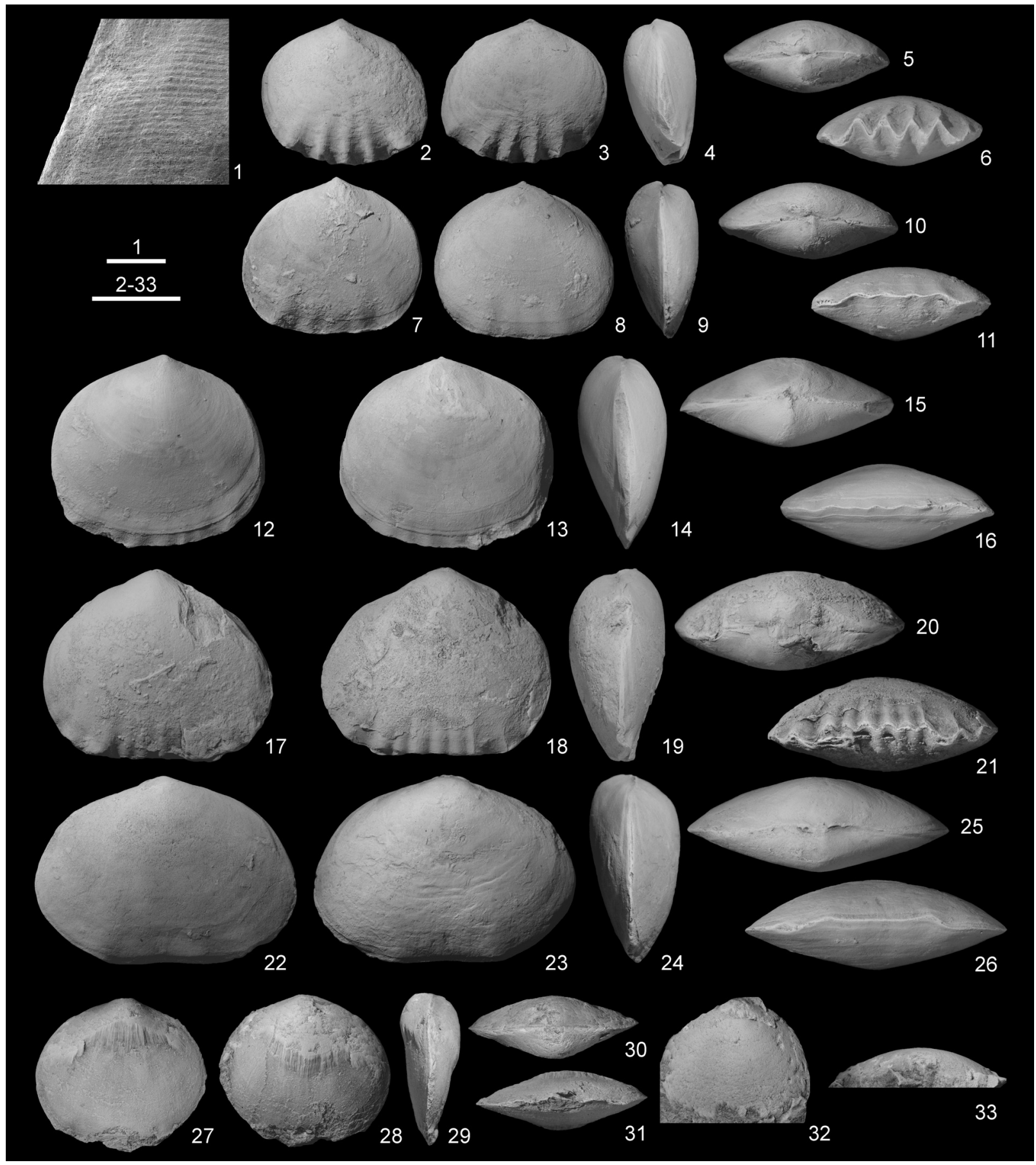

FIGURE 13. 1-26, Novaplatirostrum cf. fibrosissimum (Tietze, 1870) from the Breternitz Member (do V-VI). 1, close-up of radial capillae in sulcus of an articulated specimen (MB.B.9861), close to the anterior margin (SEM) (BreternitzEast, bed 18.1-3). 2-6, articulated specimen (MB.B.9862) in ventral, dorsal, lateral, posterior and anterior views (Fischersdorf-Gositzfelsen, bed 26.1-3). 7-11, articulated specimen (MB.B.9863) in ventral, dorsal, lateral, posterior and anterior views (Fischersdorf-Gositzfelsen, bed 23.1-3). 12-16, articulated specimen (MB.B.9864) in ventral, dorsal, lateral, posterior and anterior views (Fischersdorf-Gositzfelsen, bed 23.1-3). 17-21, articulated specimen (MB.B.9865) in ventral, dorsal, lateral, posterior and anterior views (Breternitz-East, bed 22.7-12). 22-26, articulated specimen (MB.B.9866) in ventral, dorsal, lateral, posterior and anterior views (Obernitz-Bornleite-South, bed 28.3). 27-33, Novaplatirostrum fibrosissimum (Tietze, 1870), Dzikowiec near Nowa Ruda, Lower Silesia (Poland), do VI. 2731, articulated and decorticated specimen (MB.B.9867) in ventral, dorsal, lateral, posterior and anterior views. 32-33, ventral valve (MB.B.9868) embedded in carbonate matrix in ventral and posterior views. Scale bars: 1 (1 mm), 2-33 $(10 \mathrm{~mm})$. 

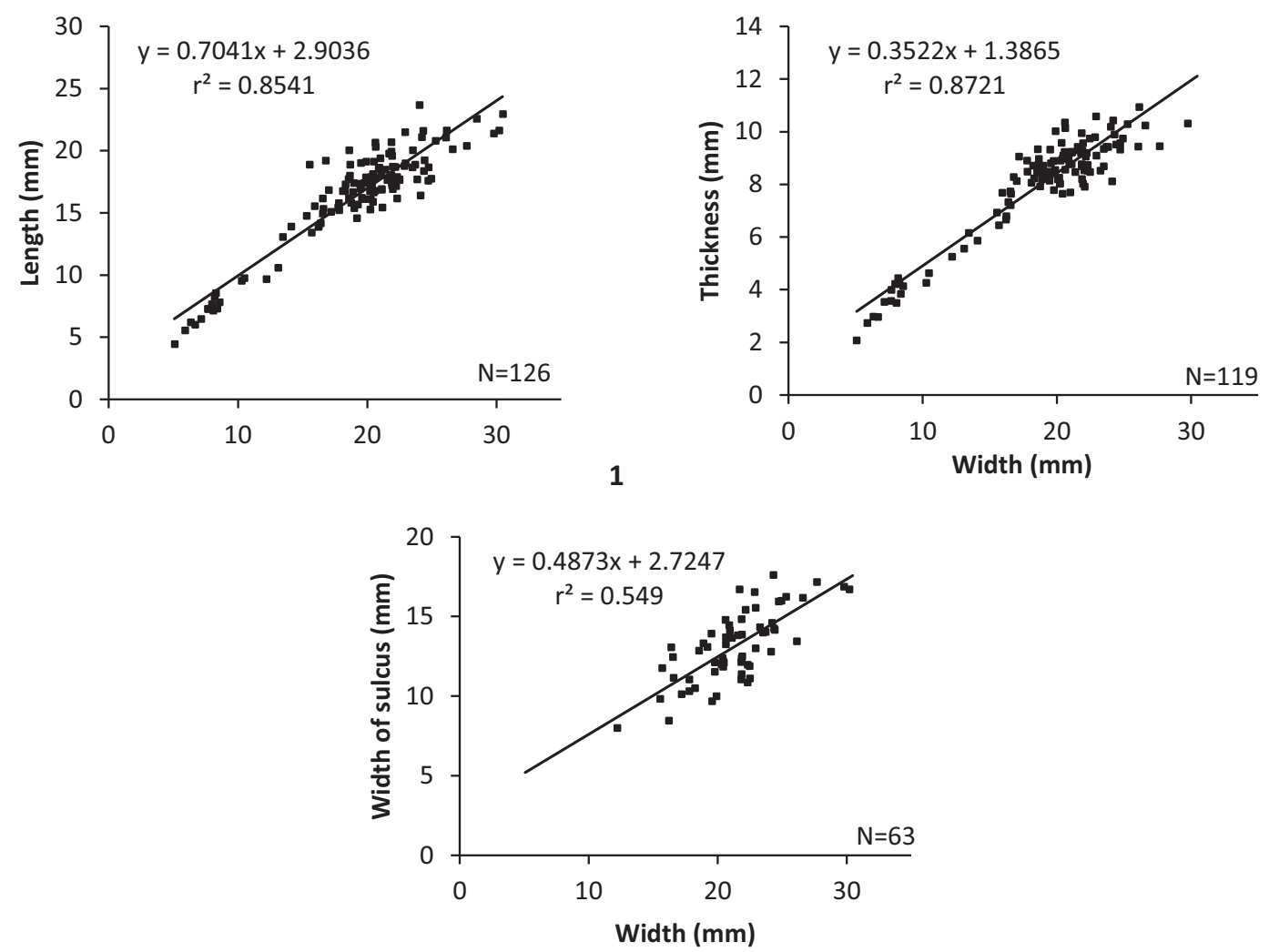

3

FIGURE 14. Scatter diagrams of Novaplatirostrum cf. fibrosissimum (Tietze, 1870). Abbreviation: N, number of specimens measured; $r^{2}$ : coefficient of linear regression. 1, Relation between shell width and length. 2, Relation between shell width and thickness. 3, Relation between shell width and sulcus width.

ately high, stretched ventrodorsally; crural bases stout; crura short, proximally triangle-shaped in section, and distally hockey-stick-shaped.

Measurements. See Figure 14 and Table 3.

Remarks. Sartenaer (1997) extensively discussed the synonymy of the Thuringian species that he considered as distinct from the contemporaneous species Novaplatirostrum sauerlandense Sartenaer, 1997 on the basis of its generally smaller size, its usually suboval and more commonly asymmetri- cal outline, its weaker ribs and the more seldom presence of lateral ribs. However, this comparison was based on only three specimens of the former. The dissymmetric outline of our material is most probably due to the schistosity affecting the Thuringian rocks and both species displaying the same size range and a variable outline. The main difference between both species lies in the distribution and strength of the ribs. The general rib formulae are $0-4 / 0-3 ; 0 ; 0$, and $4-5 / 3-4 ; 0 ; 0-2 / 0-3$ for the

TABLE 3. Measurements in mm of Novaplatirostrum cf. fibrosissimum (Tietze, 1870). Abbreviations: $L-$ length of the shell, $\mathrm{T}$ - thickness of the shell, $\mathrm{W}$ - width of the shell, $\mathrm{Wi}$ - width of the interarea, Ws - width of the sulcus.

\begin{tabular}{lccccccc}
\hline & $\mathbf{W}$ & $\mathbf{L}$ & $\mathbf{T}$ & $\mathbf{W s}$ & $\mathbf{L} / \mathbf{W}$ & $\mathbf{T} / \mathbf{W}$ & $\mathbf{W s} / \mathbf{W}$ \\
\hline $\mathrm{N}$ & 126 & 126 & 119 & 63 & 125 & 119 & 63 \\
Mean value & 19.2 & 16.4 & 8.1 & 13.1 & 0.87 & 0.43 & 0.62 \\
Standard deviation & 5.3313 & 4.0687 & 1.9596 & 2.1912 & 0.0898 & 0.0422 & 0.0740 \\
Standard error $( \pm)$ & \pm 0.474 & \pm 0.3625 & \pm 0.1796 & \pm 0.2761 & \pm 0.0080 & \pm 0.0039 & \pm 0.0093 \\
MIN & 5.1 & 4.5 & 2.1 & 8.0 & 0.68 & 0.34 & 0.49 \\
MAX & 30.5 & 23.7 & 11.0 & 17.6 & 1.22 & 0.54 & 0.80 \\
\hline
\end{tabular}


Thurigian species and $N$. sauerlandense, respectively. The median ribs are generally reduced to a faint undulation of the anterior commissure in the former. Nevertheless, we reasonably have to admit that both species are very closely related if not conspecific. When he erected $N$. sauerlandense, Sartenaer (1997) astonishingly did not discuss the Polish species Atrypa (Spirigera?) fibrosissima Tietze, 1870 from the "Clymenienkalk" of Ebersdorf near Neurode in county Glatz (now Dzikowiec near Nowa Ruda in county Klodzko, Lower Silesia), which is found in rocks of the same age and facies as Novaplatirostrum sauerlandense. The external features cited by Tietze (1870) are found in the Thuringian species, although he did not report the presence of ribs or capillae. Unfortunately, the specimen illustrated by Tietze (1870), deposited in the collections of the Geological Museum of the Institute of Geological Sciences of the Wroclaw (former Breslau) University, did not survive the destructions and the turmoil of the last world war (inspection of DW 1994 in Wroclaw). Between 1978 and 2002, one of us (DW) has collected at least four ventral valves and one articulated specimen in the type locality. The single articulated shell, which displays the first sign of a low tongue (maybe with traces of ribs) and could be an immature shell, and one ventral valve are illustrated here (Figure 13.27-33). This very limited material is insufficient to revise Tietze's (1870) species but there are enough elements to include it in Novaplatirostrum. Due to the impossibility to precisely know at this stage the range of variation of the species from the Sudetes, and thus to determine if $N$. fibrosissimum and the Thurigian species are conspecific, we tentatively compare the latter to Tietze's species. Additional material from Dzikowiec is thus required to compare $N$. fibrosissimum and the possibly also conspecific $N$. sauerlandense validly. Note that Halamski and Baliński (2009) identified material from the Holy Cross Mountains as $N$. sauerlandense that display more median ribs than the type material from the Sauerland, thus reflecting a stronger variability than that reported by Sartenaer (1997).

Occurrence. Gleitsch Formation, Breternitz Member (Figure 4).

\section{Genus ROZMANARIA Weyer, 1972}

Type species. Liorhynchus? equitans Schmidt, 1924; from the Wocklumeria-"Stufe" (do VI) of northern Sauerland, Germany.

Rozmanaria equitans (Schmidt, 1924)

Figure 4, Figure 12.26-35
1840 Terebratula subundata [n. sp.] Münster, p. 76, plate 14, figure 7 [non J. Sowerby, 1813 in 1812-1815].

* 1924 Liorhynchus? equitans n. sp. Schmidt, p. 145 , plate 7 , figures $16-17$.

1962 Plectorhynchella equitans equitans (Schmidt); Rozman, p. 176, plate 30, figure 12.

p 1972 Rozmanaria equitans (H. Schmidt); Weyer, p. 87 , plate 1 , figures $1-6$, plate 2 , figures 1 2 , non plate 2 , figures $3-4$ (= rozmanariid? gen. et sp. indet., see below) (see this author a more complete synonymy).

non 1986 Rozmanaria equitans (Schmidt, 1924); Bartzsch and Weyer, plate 1 (right column), figure 1a-b (= Thuringorhynchus pseudoequitans gen. et sp. nov., see above).

2009 Rozmanaria equitans (Schmidt, 1924); Halamski and Baliński, p. 295, figure 3A.

Material. Breternitz-E (bed 17.4): one articulated specimen; Fischersdorf-Gositzfelsen (bed 18.1-5): one articulated specimen; Reschwitz-MühlfelsenNorth (bed 18.1-2): one articulated specimen. Obernitz-Bornleite (bed 28.7-14): one articuted specimen (Weyer, 1972, plate 2, figure 1).

Description. See Weyer (1972).

Remarks. Among the material assigned to Rozmanaria equitans by Weyer (1972), two specimens (Weyer, 1972, plate 2, figures 3-4) from the Wocklumeria-"Stufe" must be transferred to another taxon, which is left in open nomenclature (= rozmanariid? gen. et sp. indet., see below) due to the lack of material, as they do not possess the characteristic bilobate outline and-present a clearly dorsibiconvex profile. It is clear that Schmidt's (1924) species corresponds to Terebratula subundata Münster, 1840 (locality Schübelhammer, Upper Franconia, Clymenia- or Wocklumeria"Stufe"; figured type preserved in the Palaeontological Institute, Bavarian State collections (no. BSPASVII852), University of München), a junior primary homonym of the Cenomanian species $T$. subundata J. Sowerby, 1813 in 1812-1815. The latter was assigned to the gibbithyridid genus Concinnithyris Sahni, 1929 (Terebratulida) by Owen (1988). This species has absolutely nothing in common with Roemerithyris macrogaster (Roemer, 1852), a probable representative of the Superfamily Martinioidea from the Upper Visean (top Asbian-Lower Brigantian) of the Harz mountains contrary to Gischler's (1994) opinion who considered $R$. equitans as a synonym of Roemer's species [see Mottequin and Weyer's (2019) redescription of $R$. macrogaster]. Thus, the specimens illustrated as Actinoconchus macrogaster by 
Gischler (1994) cannot be assigned to Roemer's species and were tentatively referred to the genus Cleiothyridina Buckman, 1906 by Mottequin and Weyer (2019). Note that the stratigraphic value of the genus Rozmanaria was discussed by Sartenaer (1998a), who stressed on the need of re-examination of the Tournaisian specimens assigned to Schmidt's species by Bartzsch and Weyer (1986). This material has been revised herein (see above). Occurrence. Gleitsch Formation, Breternitz Member (Figure 4). Outside Thuringia, Rozmanaria equitans was reported in upper and uppermost Famennian strata of the Rhenish Massif, Poland (Holy Cross Mountains) and Ural (Schmidt, 1924; Rozman, 1962; Weyer, 1972; Halamski and Baliński, 2009). Biernat (1983) cited the species in the lower Famennian of the Holy Cross Mountains, but this report is dubious according to Halamski and Baliński (2009).

\section{Rozmanariid? gen. et sp. indet.}

Figure 4, Figure 15.1-5

p 1972 Rozmanaria equitans (H. Schmidt); Weyer, p. 87 , plate 2, figures 3,4 .

Material. Breternitz-E (bed 17.4): one articulated specimen; Reschwitz-Mühlfelsen-South (bed 26.3-5): one articulated specimen.

Remarks. The available specimens display the following features: shell small-sized (ca. $6 \mathrm{~mm}$ in width) smooth, aequibiconvex, slightly wider than long, widest at about midlength, with rounded lateral margins; ventral valve strongly inflated; ventral sulcus shallow, flat-bottomed at front; dorsal valve strongly inflated, highest at front; dorsal fold high, flat-topped at front; dorsal umbo inflated. These specimens are identical to those identified as Rozmanaria equitans (Schmidt, 1924) by Weyer (1972, plate 2, figures 3 , 4) from contemporaneous strata of the Rhenish Massif and eastern Thuringia. Externally, these four specimens differ notably from Schmidt's species by their aequibiconvex to dorsibiconvex shell, their uniplicate anterior commissure and their straight anterior margin (not excavated by the ventral sulcus) whereas it is markedly excavated by a deep dorsal sulcus in $R$. equitans. The lack of data related to their internal morphology precludes a generic identification. They are tentatively included within the family Rozmanariidae on the basis of their external similarity with representatives of this family, which is particularly well-developed in the course of the Famennian.

Occurrence. Gleitsch Formation, Breternitz Member (do VI) (Figure 4). Weyer's (1972) specimens are from the Wocklumeria-"Stufe" of the Rhenish

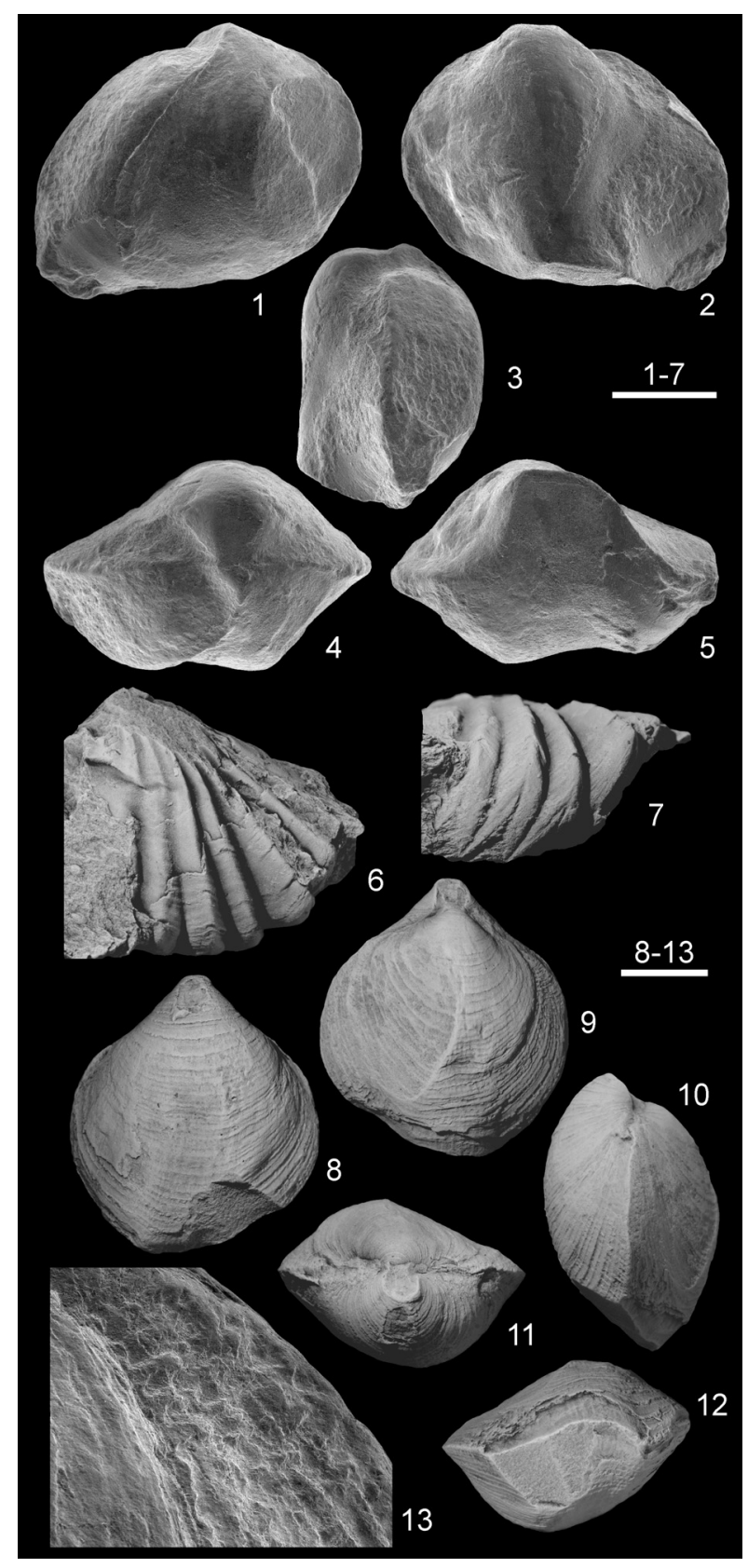

FIGURE 15. 1-5, Rozmanariid? gen. et sp. indet. from the Breternitz Member (do VI) distorted articulated specimen (MB.B.9869) in ventral, dorsal, lateral, posterior and anterior views (Reschwitz-Mühlfelsen-South, bed 26.3-5). 6-7, Allorhynchus? sp. from Pfaffenberg Member, incomplete and distorted ventral valve (MB.B.9870) in ventral and anterior views, (Pfaffenberg-SW, bed $5 \alpha$ ). 8-13, Cleiothyridina sp. indet. from the Breternitz Member, articulated specimen (MB.B.9871) in ventral, dorsal, lateral, posterior and anterior views and close-up of the flat spines (ObernitzVorderbohlen, bed 21.1-12, do VI). Scale bars: 1-5 (2 $\mathrm{mm}), 6-7(4 \mathrm{~mm}), 8-12(5 \mathrm{~mm}), 13(1 \mathrm{~mm})$. All SEM, except 6-12. 
Massif (Hönnetal railway cut section Oberrödinghausen) and eastern Thuringia (Geipel quarry in Schleiz).

\section{Superfamily Wellerelloidea Licharew (in Rzhonsnitskaya, 1956)}

Family Allorhynchidae Cooper and Grant, 1976

Genus ALLORHYNCHUS Weller, 1910

Type species. Rhynchonella heteropsis Winchell, 1865; from the Prospect Hill Sandstone (Kinderhookian), Burlington, lowa, USA.

\section{Allorhynchus? sp. indet.}

Figure 5, Figure 15.6-7

Material. Pfaffenberg-SW (bed 5a): one incomplete, distorted and partly decorticated ventral valve.

Remarks. This small-sized (ca. $14 \mathrm{~mm}$ in width) ventral valve is characterized by strong, angular costae originating from the beak (three in the sulcus; more than three on the right flank), a welldefined, wide, and shallow sulcus at front, and a relatively low tongue. Although its internal morphology is unknown, its external features suggest a tentative assignment to the long-ranging Weller's genus, which is first recorded at the base of the Kinderhookian (Carter, 1990), rather than to Pleuropugnoides Ferguson, 1966 on the basis of its low tongue and shallow sulcus. In Europe, Allorhynchus was reported in the basal Tournaisian of Bohemia in Czech Republic by Havlíček (1979), but also in the Serpukhovian-Bashkirian in the French central Pyrenees by Martínez Chacón and Delvolvé (1986).

Occurrence. Gleitsch Formation, Pfaffenberg Member (duplicata conodont Zone) (Figure 5).

Order ATHYRIDIDA Boucot et al., 1964

Suborder ATHYRIDIDINA Boucot et al., 1964

Superfamily ATHYRIDOIDEA Davidson, 1881

Family ATHYRIDIDAE Davidson, 1881

Subfamily CLEIOTHYRIDININAE Alvarez et al., 1998

Genus CLEIOTHYRIDINA Buckman, 1906

Type species. Atrypa pectinifera J. de C. Sowerby, 1840; from the Upper Permian (lower Zechstein, middle Wuchiapingian) of Humbleton Hill, County Durham, England.

Cleiothyridina sp. indet.

Figure 4, Figure 15.8-13

Material. Obernitz-Vorderbohlen (bed 21.1-12): one articulated specimen.

Remarks. This elongate specimen with a slightly uniplicate anterior commissure is covered by densely crowded growth lamellae that projects as flat spines anteriorly and anterolaterally. These external features are suggestive of Cleiothyridina rather than Crinisarina Cooper and Dutro, 1982 which is more strongly uniplicate and pentagonal in outline. Although markedly smaller, this specimen might be related to the elongate specimens identified as Cleiothyridina struniensis (Dehée, 1929) by Halamski and Baliński (2009) from the most probably uppermost Famennian of the South Polish shelf [see also discussion in Mottequin and Brice (2016) about the generic assignment of Dehée's species]. Occurrence. Gleitsch Formation, Breternitz Member (lower Wocklumeria-"Stufe") (Figure 4).

Cleiothyridina pfaffenbergensis sp. nov. Figure 5, Figure 16, Figure 17

\section{zoobank.org/F83DCDFC-2001-44D4-84C7-5AF54BC137CA}

Etymology. In reference to the type locality of the species (Pfaffenberg, southeast of Saalfeld).

Holotype. An articulated specimen (MB.B.9875) (Figure 16.19-23), from the locality PfaffenbergNE (bed 1, nodule layer) (Figures 2.1, 4).

Additional material. Pfaffenberg-NE (beds 1, 2, 7, 9a): 13 articulated specimens and one ventral valve; Pfaffenberg-SW (beds 1-4, 5ס, 6a): 14 articulated specimens, 18 ventral and one dorsal valves; Kahlleite-quarry-E-I (bed 3): one articulated specimen; Kahlleite-quarry-E-II: one articulated specimen.

Type locality. Pfaffenberg-NE (Figure 2.1).

Type stratum. Gleitsch Formation, Pfaffenberg Member (Tournaisian, Hastarian), Acutimitoceras prorsum Zone $=$ Protognathodus kockeli Zone (former Upper Siphonodella praesulcata Zone) (Figures 3,5$)$.

Diagnosis. Shell small-sized (up to $7.4 \mathrm{~mm}$ in width), ovate in outline, longer than wide, widest slightly posteriorly to mid-length, dorsibiconvex to ventribiconvex; anterior margin straight to poorly emarginate; anterior commissure rectimarginate to slightly undulose (dorsally directed); sulcus shallow, poorly delimited, only perceptible close to the anterior margin; fold undeveloped; growth lamellae densely crowded (6 per $1 \mathrm{~mm}$ ).

Description. Shell small-sized (up to $7.4 \mathrm{~mm}$ in width), ovate in outline, longer than wide, widest slightly posteriorly to mid-length, dorsibiconvex to ventribiconvex; anterior margin straight to poorly emarginate; anterior commissure rectimarginate to slightly undulose (dorsally directed). Ventral valve regularly convex in posterior and lateral profile views, with flanks slopping gently to moderately towards lateral commissures; beak erect to incurved, truncated by large, permesothyrid foramen; palintropes small, concave; sulcus shallow, 


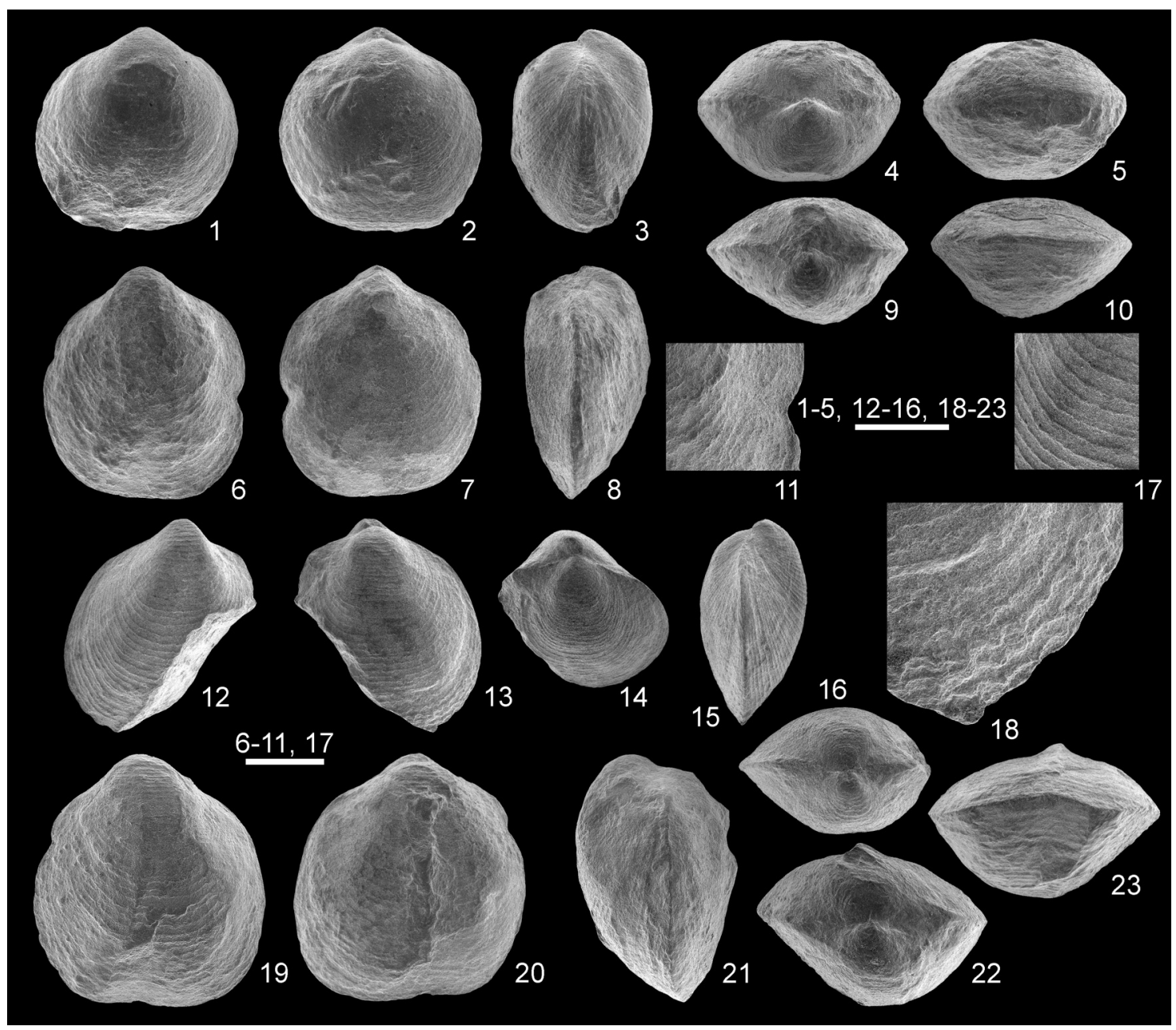

FIGURE 16. Cleiothyridina pfaffenbergensis sp. nov. from the Pfaffenberg Member (Pfaffenberg-NE and SW). 1-5, articulated specimen (MB.B.9872) in ventral, dorsal, lateral, posterior and anterior views (bed 3 SW). 6-11, articulated specimen (MB.B.9873) in ventral, dorsal, lateral, posterior and anterior views, and detail of predation trace on ventral valve (bed $1 \mathrm{NE}$, nodules). 12-18, incomplete articulate specimen (MB.B.9874) in ventral, dorsal, oblique dorsal, lateral and posterior views, and details of growth lamellae in ventral valve and on dorsal valve with spinous projections (bed $1 \mathrm{NE}$, nodules). 19-23, articulated specimen (holotype, MB.B.9875) in ventral, dorsal, lateral, posterior and anterior views, (bed $1 \mathrm{NE}$, nodules). Scale bars: 1-5 and 6-10 (2 mm), 11 and $17(1 \mathrm{~mm}), 12-16$ and 19-23 (3 mm), and 18 $(800 \mu \mathrm{m})$. All SEM.

poorly delimited, only perceptible close to the anterior margin; if developed, tongue corresponding to a vague dorsally directed undulation not perpendicular to commissural plane. Dorsal valve regularly convex in posterior and lateral profile views, highest near mid-valve, then decreasing near anterior margin; fold undeveloped.

Ornamentation of densely crowded growth lamellae $(6$ per $1 \mathrm{~mm}$ in the central part of the shell), projecting anteriorly and anterolaterally as flat, solid spines (rarely preserved) (Figure 16.1218).
Ventral interior (Figure 17) with thin, short and vertical dental plates supporting small and subrectangular teeth in transverse section; central apical cavity wide; lateral apical cavities strongly filled in by callus. Dorsal interior (Figure 17) with almost flat cardinal plate (not possible to differentiate inner and outer hinge plates); dental sockets deep; only some fragments of spiral cones observed.

Remarks. Cleiothyridina pfaffenbergensis sp. nov. is slightly smaller than two relatively similar Carboniferous North American species, namely $C$. tenuilineata (Rowley, 1900) (see Carter, 1967, 


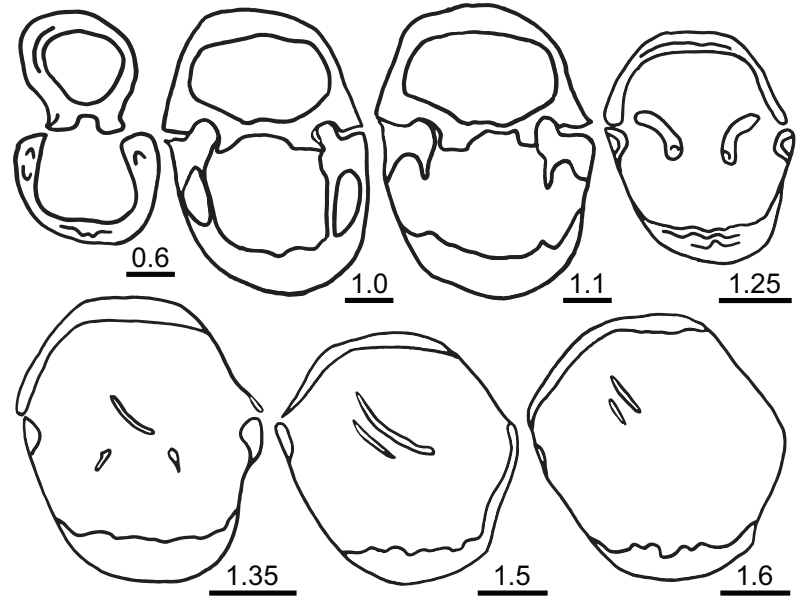

FIGURE 17. Transverse serial sections of Cleiothyridina pfaffenbergensis sp. nov. from the Pfaffenberg Member (Pfaffenberg-SW, bed 1, nodules) (MB.B.9876). Numbers refer to distances in $\mathrm{mm}$ from the tip of the ventral umbo. Scale bars: $1 \mathrm{~mm}$ for all, except sections $0.6,1.0$, and $1.1(500 \mu \mathrm{m})$

1987) and C. hirsuta (Hall, 1858), notably on the basis of the rectimarginate or vaguely undulose anterior commissure, and thus the poor development of sulcus. However, the German species is clearly longer than wide and has thus a different outline.

Occurrence. Gleitsch Formation, Pfaffenberg Member (kockeli-sandbergi conodont zones) (Figure 5). A poorly preserved and slightly larger specimen from the Buschteich quarry (Göschitz Formation, Löhma Member) might be assigned to this species.

\section{Subfamily SPIRIGERELLINAE Grunt, 1965 Genus COMPOSITA Brown, 1845}

Type species. Spirifer ambiguus Sowerby, 1822 in 1821-1822; from the Visean of Derbyshire, England.

Composita? sp. indet.

Figure 3, Figure 4, Figure 18

Material. Pfaffenberg-NE (beds $3,8 \alpha, 8 \beta$ ): six articulated specimens; Pfaffenberg-SW (beds 3, 4, $5 \alpha, 5 \beta, 5 \delta)$ : ten articulated specimens and two ventral valves.

Description. Shell small-sized (up to $4.8 \mathrm{~mm}$ in width); slightly wider than long to longer than wide, widest at about midlength or slightly anteriorly to it; aequibiconvex to ventribiconvex, ovate in outline; anterior margin rounded; anterior commissure rectimarginate; impunctate shell.

Ventral valve regularly convex in posterior and lateral profiles, with flanks slopping moderately

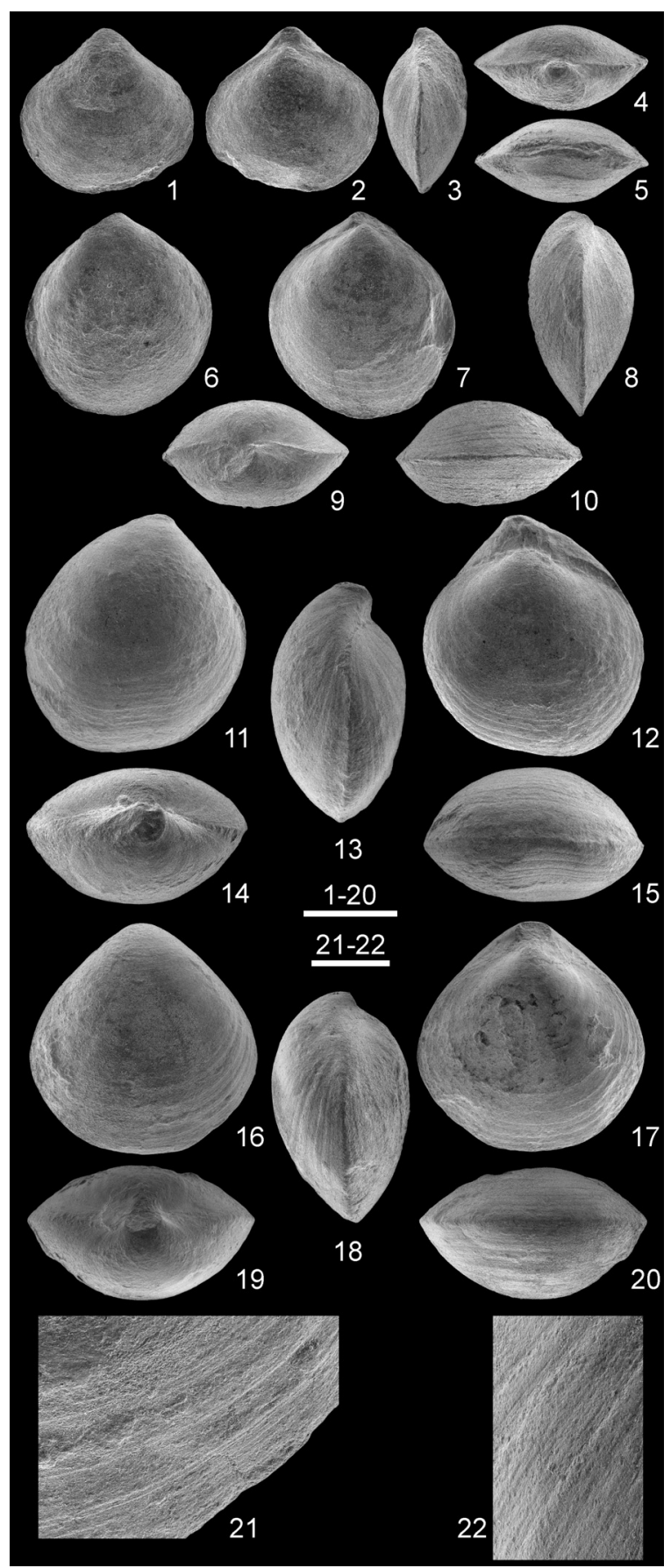

FIGURE 18. Composita? sp. indet. from the Pfaffenberg Member (Pfaffenberg-SW). 1-5, articulated specimen (MB.B.9877) in ventral, dorsal, lateral, posterior and anterior views (bed 3). 6-10, articulated specimen (MB.B.9878) in ventral, dorsal, lateral, posterior and anterior views (bed 3). 11-15, articulated specimen (MB.B.9879) in ventral, dorsal, lateral, posterior and anterior views (bed $5 \delta$ ). 16-22, articulated specimen (MB.B.9880) in ventral, dorsal, lateral, posterior and anterior views, and detail of the concentric ornamentation (bed 3). Scale bars: 1-20 (2 mm), 21-22 $(400 \mu \mathrm{m})$. All SEM. 
towards lateral commissures; umbo not or poorly individualized; beak erect to slightly incurved; foramen poorly preserved for precise description; no sulcus. Dorsal valve regularly convex in posterior and lateral profile, highest at mid-valve or posteriorly to it, then decreasing towards anterior commissure; no fold.

Ornamentation of irregularly spaced growth varices and growth microlines.

Transverse serial sections in one specimen revealed the presence of dental plates in ventral valve, but its dorsal interior was not preserved.

Remarks. The identification of this poorly preserved material is only tentative. External analogies can be made with small-sized, but larger Composita species from the Carboniferous of North America (e.g., Weller, 1914; Carter, 1987), but further material is needed to reach a better identification.

Occurrence. Gleitsch Formation, Pfaffenberg Member (sulcata-sandbergi conodont zones) (Figure 5).

Order SPIRIFERIDA Waagen, 1883

Spiriferide gen. et $\mathrm{sp}$. indet.

Figure 4, Figure 19.1-3

Material. Fischersdorf-West (bed 32.5): one incomplete, distorted ventral valve.

Remarks. It is one of the very rare spiriferides recovered from the uppermost Famennian strata of the Saalfeld area. The flanks of this minute and impunctate ventral valve are covered by at least five (exact number unknown due to poor preservation) wide, simple and round-topped ribs. The sinus is very shallow and smooth. Numerous capillae are present. This very limited material is currently impossible to identify at the generic level.

Occurrence. Gleitsch Formation, Breternitz Member (Wocklumeria sphaeroides ammonoid Zone) (Figure 4).

Suborder SPIRIFERIDINA Waagen, 1883

Superfamily AMBOCOELIOIDEA George, 1931

Family AMBOCOELIIDAE George, 1931

Subfamily AMBOCOELIINAE George, 1931

Genus CRURITHYRIS George, 1931

Type species. Spirifer urei Fleming, 1828; from the Visean of Strathaven, Lanarkshire, Scotland.

Crurithyris sp. indet.

Figure 5, Figure 19.4-17

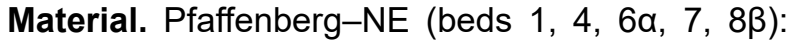
six articulated specimens, 11 ventral valves; Pfaffenberg-SW (beds 2-4, 5 $\beta, 6 \delta$ ): three articulated specimens, 11 ventral valves and two dorsal valves; Fischersdorf-West (bed 3): one ventral valve.

Description. Shell small-sized (up to $4.6 \mathrm{~mm}$ in width), wider than long, widest at mid-length, markedly ventribiconvex; hinge line narrower than greatest width; anterior margin straight; anterior commissure rectimarginate. Ventral valve regularly convex in posterior and lateral profile views, with flanks sloping moderately towards lateral commissures; umbo strongly prominent; beak curved; interarea high, catacline at the base then becoming apsacline, concave; delthyrium bordered by narrow deltidial plates; median sulcus poorly developed. Dorsal valve highest in the posterior third part of the valve, then decreasing anteriorly; interarea rectilinear, anacline, flat.

Shell is smooth with some growth lines and numerous, concentrically arranged spine bases.

Ventral interior (Figure 19.14-15) with muscle scars (narrow diductor muscle scars) separated medially by a long myophragm. Dorsal interior is unknown.

Remarks. These specimens indubitably belong to Crurithyris on the basis of their external (e.g., shell strongly ventribiconvex, spinous microornament) and internal (e.g., absence of dental plates) morphology. From the specific assignment viewpoint, the relatively poor preservation of the Thuringian specimens precludes a confident identification. As recently stressed by Mottequin et al. (2015b) and Mottequin and Simon (2017), Tournaisian and Visean Crurithyris species from Western Europe need to be revised, notably those described and/or discussed by George (1931).

Occurrence. Gleitsch Formation, Pfaffenberg Member (sulcata-sandbergi conodont zones) (Figure 5).

Crurithyris? sp. indet.

Figure 4, Figure 19.18-22

Material. Obernitz-Bornleite-North (bed 21.122.12): one articulated specimen.

Remarks. This identification is made for a tiny, smooth and markedly ventribiconvex ambocoeliid with a subcircular outline and a strong ventral umbo. Its ventral valve bears a shallow sulcus originating close to the tip of the umbo. The external morphology suggests a tentative assignment to Crurithyris in the absence of knowledge of its internal morphology. Consequently, it is not currently possible to demonstrate that the specimens identified as Crurithyris sp. indet. from the Pfaffenberg Member and this single one from the Breternitz Member are conspecific. Further material from Breternitz Member is thus required to solve this issue. 


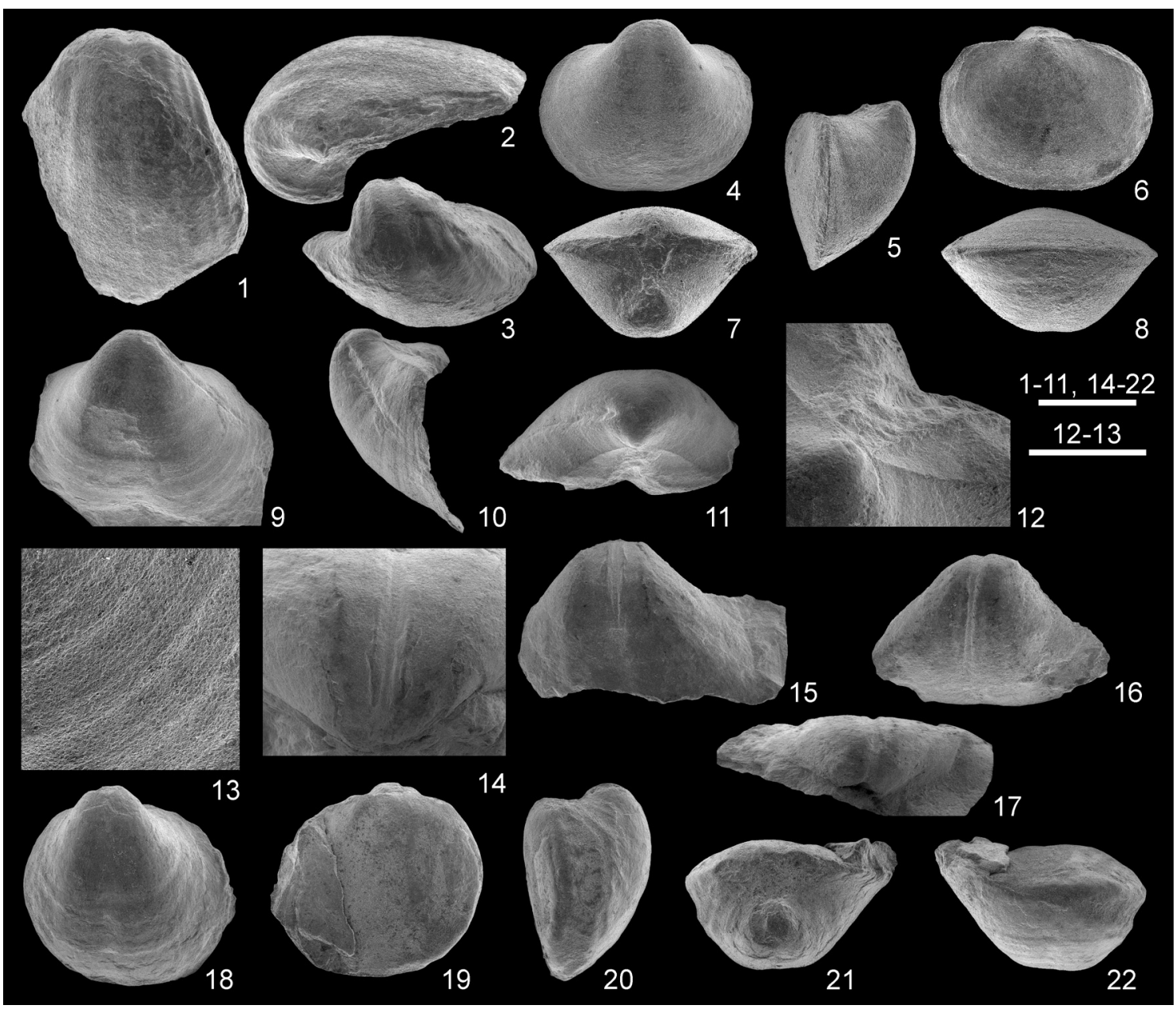

FIGURE 19. 1-3, Spiriferide gen. et sp. indet. from the Breternitz Member (Fischersdorf-West, bed 32.5, upper do VI), incomplete and distorted ventral valve (MB.B.9881) in ventral, lateral and posterior views. 4-17, Crurithyris sp. indet. from the Pfaffenberg Member (Pfaffenberg-NE and SW). 4-8, articulated specimen (MB.B.9882) in ventral, lateral, dorsal, posterior and anterior views (bed 4 NE). 9-13, almost complete ventral valve (MB.B.9883) in ventral, lateral and posterior views, detail of the interarea showing the narrow deltidial plates, and close-up of the microornament on the right flank (bed $4 \mathrm{NE}$ ). 14-15, incomplete ventral interior (MB.B.9884), detail of the muscle field and ventral view (bed 4SW). 16-17, incomplete ventral interior (MB.B.9885) in ventral and posterior views (bed 5 $\beta$ SW). 18-22, Crurithyris? $\mathrm{sp}$. indet. from the Breternitz Member (do VI) (Obernitz-Bornleite-North, bed 21.1-22.12), slightly distorted, articulated specimen (MB.B.9886) in ventral, dorsal, lateral, posterior and anterior views. Scale bars: 1-11, 15, and 18-22 (2 $\mathrm{mm}), 12,14$ and 16-17 (1 mm), $13(600 \mu \mathrm{m})$. All SEM.

Occurrence. Gleitsch Formation, Breternitz Member (do VI) (Figure 4).

Superfamily MARTINIOIDEA Waagen, 1883

Family CRASSUMBIDAE Carter (in Carter and Gourvennec, 2006) Genus CRASSUMBO Carter, 1967

Type species. Crassumbo inornatus Carter, 1967; from the Chappel Limestone (Kinderhookian), McCulloch County, Central Texas, USA.

Crassumbo germanicus sp. nov.

Figure 5, Figure 20, Figure 21, Figure 22, Table 4
zoobank.org/EA7FF709-94FB-4C6C-910E-FFF94A96FE8D

1848 Delthyris sp.; Richter, p. 45, plate 6, figure 210.

? 1954 Spirifer (Martinia) cf. globosa; Pfeiffer, p. 69.

v 1979 Crassumbo? n. sp.; Weyer, p. 100.

v 1986 Crassumbo? n. sp.; Bartzsch and Weyer, plate 1 (right column), figure 3 .

v 2015 Martinia? nov. sp.; Bartzsch et al., figure 14.3 (Brachiopoda) (copy of Bartzsch and Weyer, 1986). 
Etymology. From Germanicus, a, um (Latin): Germanic.

Holotype. An articulated specimen (MB.B.9891) (Figure 20.21-25) from the locality Pfaffenberg-SW (bed 4) (Figure 2.1, Figure 5).

Additional material. Pfaffenberg-NE (beds 1, 3, $4,5 \alpha-\gamma, 6 \delta, 10 \alpha): 34$ articulated specimens, 24 ventral and five dorsal views, and 12 ventral and four dorsal interiors; Pfaffenberg-SW (beds 1-5y, $6 \alpha, 6 \delta): 53$ articulated specimens, 57 ventral and 13 dorsal valves, and 59 ventral and 36 dorsal interiors. Kahlleite quarry-E-II (beds 3,4 ): one articulated specimen and one ventral valve.

Type locality. Pfaffenberg-NE (Figure 2.1).

Type stratum. Gleitsch Formation, Pfaffenberg Member (Tournaisian, Hastarian) (Figures 3, 5).

Diagnosis. A small species of Crassumbo (up to $15.3 \mathrm{~mm}$ in width) wider than long, widest at midlength, ventribiconvex, subquadrate to transversally ovate in outline. Sulcus poorly defined, very shallow, flat to round-bottomed at front. Fold absent or only visible close to anterior margin in some adult specimens. Shell devoid of ribbing, but with numerous irregularly spaced growth lamellae bearing ca. 19 capillae per $\mathrm{mm}$.

Description. Shell small-sized (up to $15.3 \mathrm{~mm}$ in width), wider than long, widest at mid-length, markedly ventribiconvex, subquadrate to transversally ovate in outline; hinge line narrower than maximal width; cardinal margins rounded; anterior margin straight; anterior commissure uniplicate. Ventral valve with flanks slopping moderately towards lateral commissures; umbo prominent; beak curved; interarea catacline at its base then becoming apsacline, concave, high; delthyrium large, bordered by prominent deltidial plates; sulcus large, inconspicuously originating in the umbonal area, poorly delimited, very shallow, flat to round-bottomed at front; tongue subtrapezoidal to semi-elliptic in outline, relatively low, almost perpendicular to commissural plane in adults. Dorsal valve highest at mid-valve or posteriorly to it, then progressively decreasing towards anterior margin; umbo small; interarea rectilinear, anacline, flat; fold absent or very low, only perceptible close to anterior margin in some adult specimens, round-topped at front.

Ornamentation of some irregularly spaced growth lamellae; microornament of numerous capillae (ca. 19 per mm) (Figure 20.27).

Ventral valve interior (Figures 20.28-29, 21) with relatively long, intrasinal and divergent dental plates (21-43 degrees, $n=7$ ), converging dorsally in umbonal region (as seen in transverse section), but becoming much less convergent to almost par- allel more anteriorly; teeth small; muscle field poorly impressed in valve floor. Dorsal valve interior (Figures 20.30-35, 21) with unsupported ctenophoridium (number of lamellae unknown); dental sockets small; dorsal adminicula connecting the crural bases to the valve floor (Figure 20.30-31) well-developed (Figure 20.30-32) or obscured by callus deposits (Figure 21); crural bases dorsally convergent; adductor scars impressed, separated by a thin myophragm; vascula media canals welldeveloped; spiralia laterally directed, with four whorls.

Measurements. See Figure 22 and Table 4.

Remarks. The morphological characters of the Thuringian species fit well with the diagnosis of Crassumbo, except the absence of scattered nodes developed on the capillae. This genus was firstly reported in the top of the Kinderhookian succession of Texas (Carter 1967, 1990). Crassumbo germanicus sp. nov. differs from the Texan species C. inornatus Carter, 1967 by its smaller size, its proportionately higher ventral interarea and the absence of strong callosities in ventral and dorsal valves which obscure the cardinalia in the latter. The German species is distinguished from Crassumbo turgidus Carter, 1967, also from Texas, by its less developed fold and sulcus and its dorsal valve clearly shorter than the ventral one. Crassumbo germanicus sp. nov. is markedly smaller than the eastern Australian species C. gresfordensis Qian and Roberts, 1995. Moreover, the former is devoid of ribs and has a less developed sulcus. Crassumbo germanicus sp. nov. cannot be confused with C.? jonesi Roberts, 1971 from northwestern Australia notably due to its lack of ribbing, its markedly lower tongue and its clearly less inflated dorsal valve.

Occurrence. Gleitsch Formation, Pfaffenberg Member (kockeli-quadruplicata conodont zones) (Figure 5).

Suborder DELTHYRIDINA Ivanova, 1972 Superfamily DELTHYRIDOIDEA Phillips, 1841

Family MUCROSPIRIFERIDAE Boucot, 1959

Subfamily TYLOTHYRIDINAE Carter, 1972 Genus TEXATHYRIS Carter, 1972

Type species. Texathyris elegantula Carter, 1972; from the Chappel Limestone (Kinderhookian), San Saba County, central Texas, USA.

Texathyris? tarpata (Schmidt, 1924) Figure 5, Figure 23, Figure 24

v* 1924 Spiriferina tarpata n. sp. Schmidt, p. 158, plate 8, figures 34-36. 


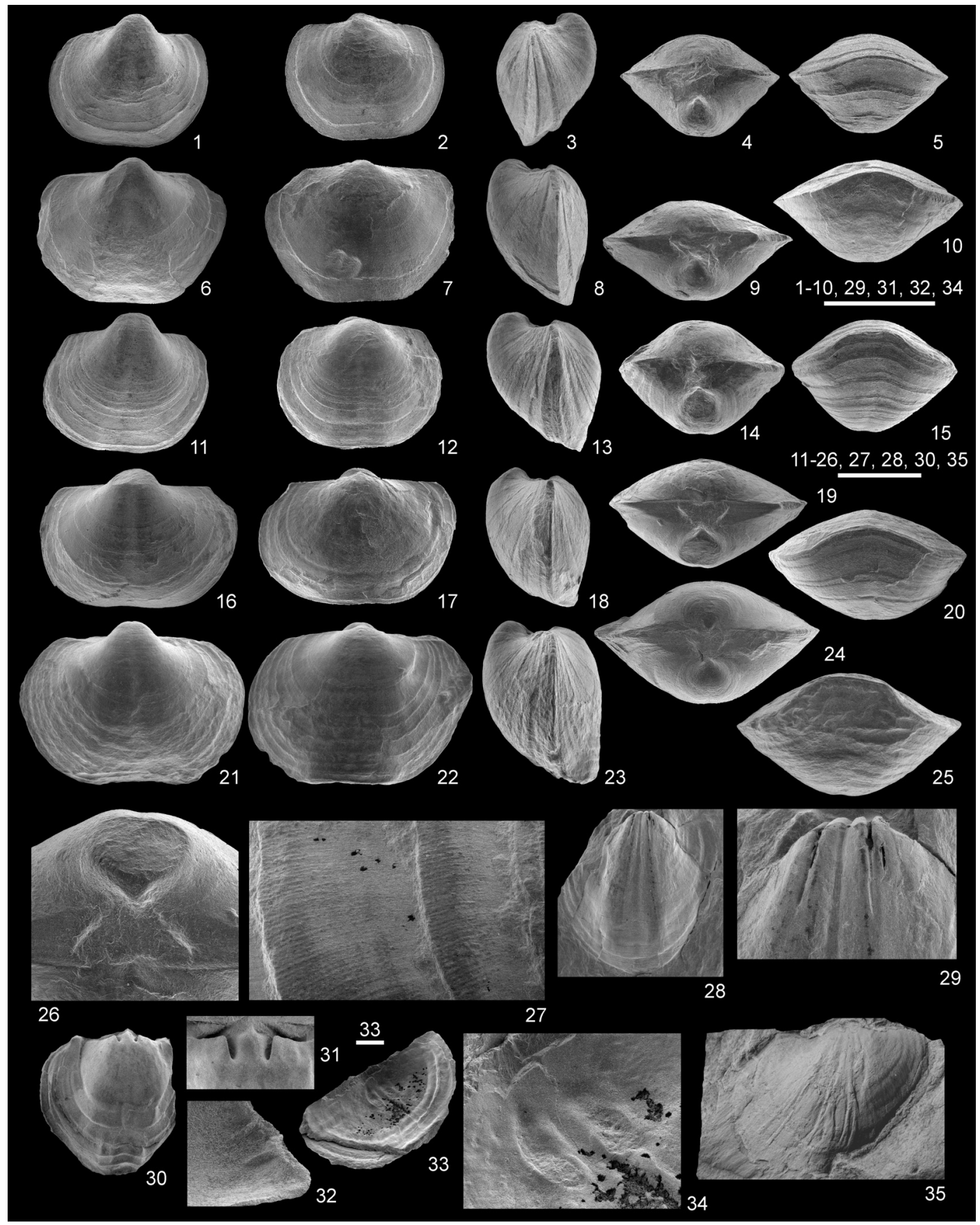

FIGURE 20. Crassumbo germanicus sp. nov. from the Pfaffenberg Member (Pfaffenberg-NE and SW). 1-5, slightly distorted articulated specimen (MB.B.9887) in ventral, dorsal, lateral, posterior and anterior views (bed 5a SW). 6-10, almost complete specimen (MB.B.9888) in ventral, dorsal, lateral, posterior and anterior views (bed 5y NE). 11-15, articulated specimen (MB.B.9889) in ventral, dorsal, lateral, posterior and anterior views (bed 3SW). 16-20, 26, articulated specimen (MB.B.9890) in ventral, dorsal, lateral, posterior and anterior views and detail of the delthyrium bordered by narrow deltidial plates (bed 4 SW). 21-25, articulated specimen (holotype, MB.B.9891) in ventral, dorsal, lateral, posterior and anterior views (bed 4SW). 27, Close-up of the growth lamellae and capillae on ventral valve of an articulated specimen (MB.B.9892) (bed $5 \alpha$ SW). 28-29, incomplete ventral internal mould specimen (MB.B.9893) and detail of the muscle field and dental plates (bed 4SW). 30-32, incomplete dorsal internal mould (MB.B.9894) in dorsal view, detail of the posterior region, lateral oblique view of the latter (bed $3 \mathrm{SW}$ ). 33-34, incomplete dorsal interior (MB.B.9895) in lateral oblique view and detail of the muscle field (bed $4 \mathrm{SW}$ ). 35, incomplete dorsal mould (MB.B.9896) with well-preserved vascular canals (bed 4 SW). Scale bars: 1-10, 11-25, 28, 30, and 35 (5 mm), 26, 29, 33, 31, 32 and 34 (2 mm), 27 (1 mm). All SEM, except 35. 


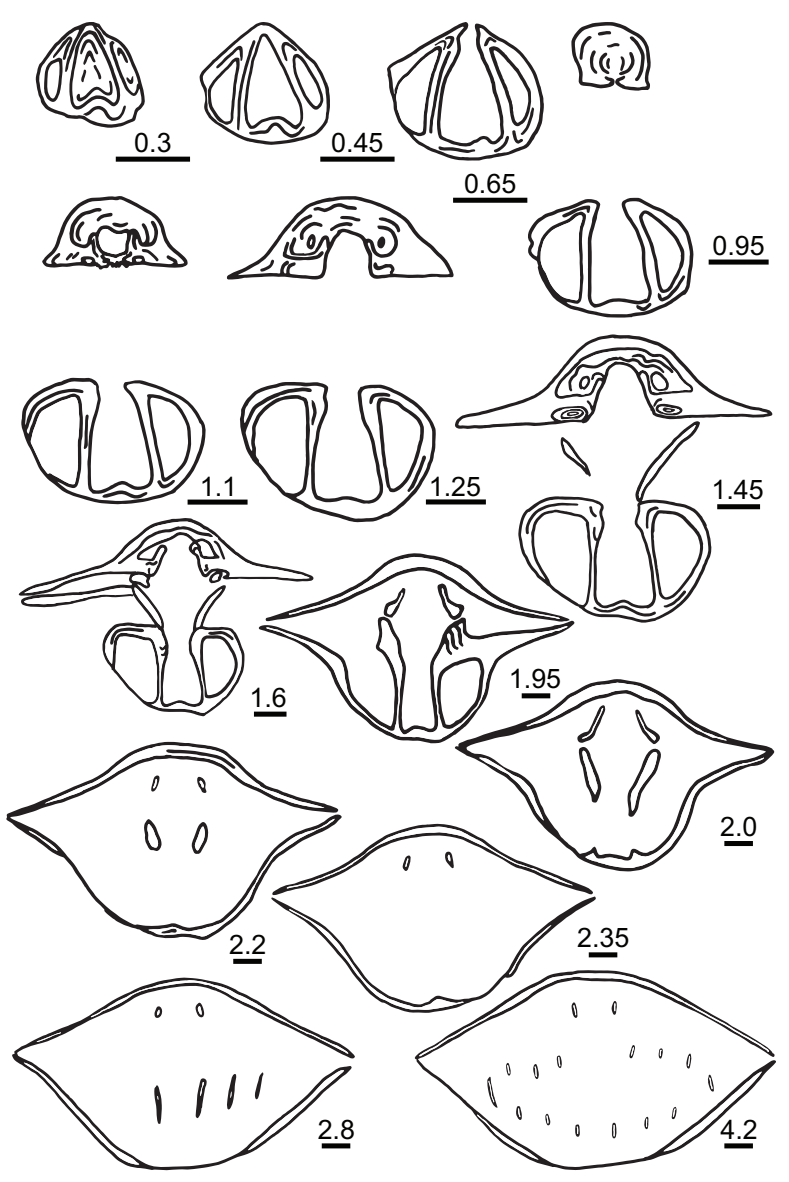

FIGURE 21. Transverse serial sections of Crassumbo germanicus sp. nov. from the Pfaffenberg Member (Pfaffenberg-SW, bed 5 $\beta$ ) (MB.B.9897). Numbers refer to distances in $\mathrm{mm}$ from the tip of the ventral umbo. Scale bars: $1 \mathrm{~mm}$.

1996 "Spiriferina” tarpata Schmidt; Becker, p. 25, plate 3, figures 15-19.

Types. The type material is from Stockum (Acutimitoceras prorsum ammonoid Zone and Protognathodus kockeli conodont Zone) in Sauerland, Rhenish Slate Mountains. The ventral valve BGRX5732 (Figure 23.1-4), illustrated by Schmidt (1924, plate 8 , figure 35 ), is selected here as the lectotype whereas the dorsal valve BGR-X5731 (Schmidt, 1924, plate 8, figure 34; Figure 23.11-15) is a paralectotype as is the case of a second smaller ventral valve (associated to BGR-X5731; Figure 23.5-10) and of a second incomplete dorsal valve (associated to BGR-X5732; Figure 23.1620).

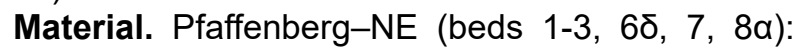
seven articulated specimens, seven ventral and eight dorsal valves, four dorsal moulds; Pfaffen-

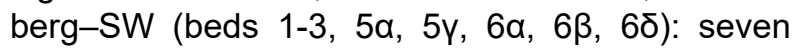
articulated specimens, five ventral and six dorsal valves, two ventral and five dorsal internal moulds; Fischersdorf-Gositzfelsen (bed 1): one articulated specimen and one dorsal valve; Fischersdorf-East (bed 7): one dorsal valve.

Description. Shell small-sized (up to ca. $14 \mathrm{~mm}$ in width), wider than long, widest at mid-length, biconvex, rounded trapezoidal in outline; hinge line narrower than maximum width; cardinal margins rounded; anterior margin straight; anterior commissure uniplicate. Ventral valve regularly convex in posterior and lateral profile views, with flanks slopping moderately towards lateral commissures; beak strongly curved; interarea low, catacline at its base, then becoming apsacline, concave; delthyrium unobserved (cancelled by sediment); sulcus originating at umbo, well-defined, wide, shallow, flat-bottomed at front; tongue almost perpendicular or perpendicular to commissural plane, high, rounded in outline. Dorsal valve highest at mid-valve or anteriorly to it, then decreasing towards anterior margin; fold originating at front, well-defined by two grooves, round- to flat-topped at front leaving aside the median groove occurring in some specimens; interarea rectilinear, anacline, flat.

Flanks covered by at least seven rounded (poorly preserved!) and simple ribs separated by similar grooves, obsolescent near posterolateral margins; fold and sulcus smooth; numerous irregularly spaced concentric lamellae; concentric microlines numerous (ca. 10 per $0.5 \mathrm{~mm}$ ); possible traces of capillae (Figure 23.10, 34).

Ventral interior (Figures 23.8, 24) with short, thickened, vertical and extrasinal dental plates; teeth short, rounded in transverse section; central and lateral apical cavities not filled in by shelly material; median septum moderately long, high. Dorsal interior (Figure 24) with unsupported ctenophoridium (number of lamellae unknown); crural bases dorsally convergent; spiralia not preserved (fragments of whorls observed).

Remarks. As its shell is impunctate, Spiriferina tarpata Schmidt, 1924 cannot be included in a spiriferinide genus. Its general shape, prominent growth lamellae, smooth fold and sulcus and the presence of a strong ventral median septum strongly suggest an assignment to Texathyris Carter, 1972, which is only recorded with certainty in the Tournaisian of central Texas. Nonetheless, the absence of strong sulcus-bounding ribs and of foldbounding ridges makes this generic identification doubtful. Moreover, Carter (1972) did not report the presence of capillae in Texathyris elegantula Carter, 1972, but this may be due to preservation bias. 

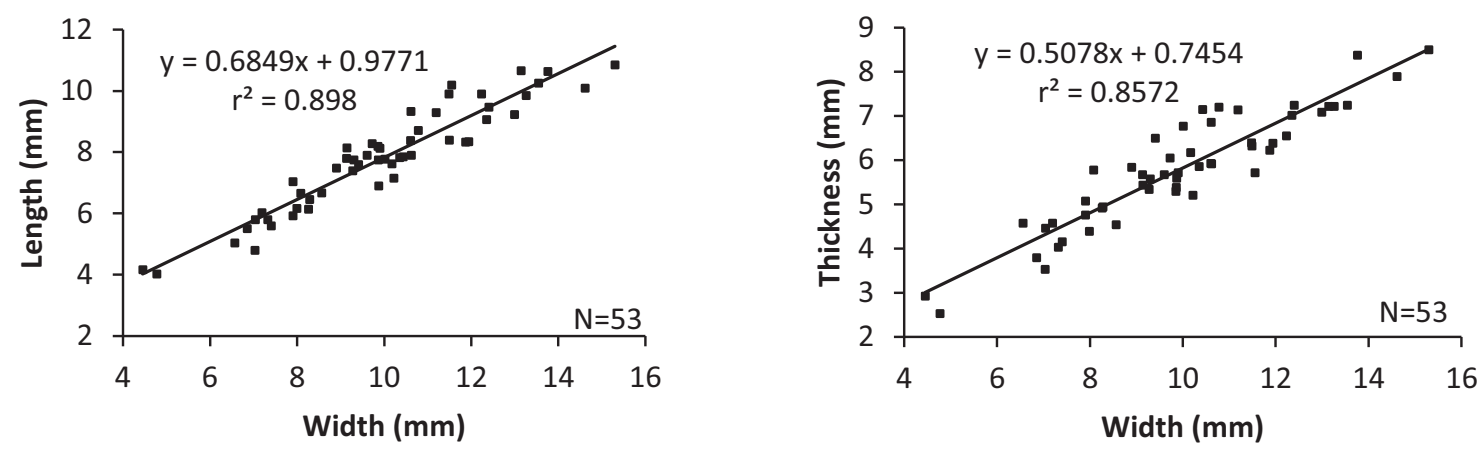

1
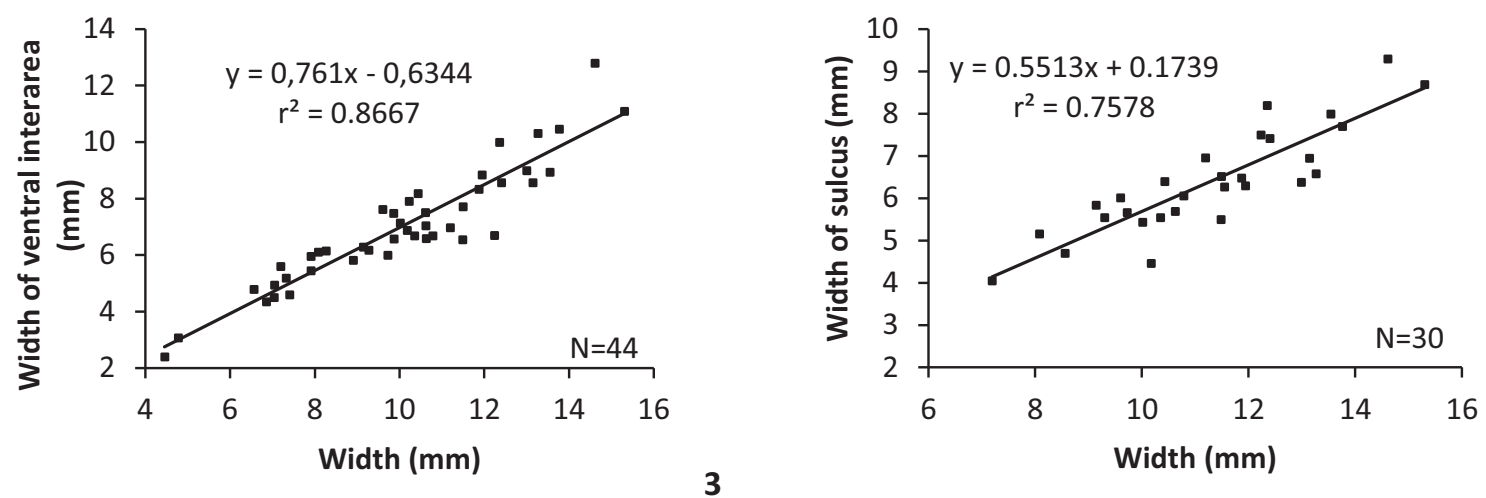

3

4

FIGURE 22. Scatter diagrams of Crassumbo germanicus sp. nov. Abbreviations: $N$, number of specimens measured; $r^{2}$ : coefficient of linear regression. 1, Relation between shell width and length. 2, Relation between shell width and thickness. 3, Relation between shell width and ventral interarea width. 4, Relation between shell width and sulcus width.

Contrary to the definition of the subfamily Tylothyridinae (Tylothyris North, 1920 and Texathyris) by Johnson and Hou (2006), who indicated the absence of radial microornament, it appears that the type species of Tylothyris, i.e. T. laminosa (M'Coy 1841), displays capillae which are only observed in particularly well-preserved material (Mottequin and Simon 2017). Due to preservation bias, such a microornament was not observed in $T$. laminosa specimens from its type locality by Brunton (1984), Bassett and Bryant (2006) and Mottequin (2010).

Occurrence. Gleitsch Formation, Pfaffenberg Member (kockeli-sandbergi conodont zones) (Figure 5). Schmidt (1924) described his species on the basis of material from the basal Tournaisian of the Rhenish Slate Massif (see above). Péneau (1928) doubtfully assigned material from the upper

TABLE 4. Measurements in mm of Crassumbo germanicus sp. nov. Abbreviations: $L-$ length of the shell, $T-$ thickness of the shell, $\mathrm{W}$ - width of the shell, $\mathrm{Wi}$ - width of the interarea, Ws - width of the sulcus.

\begin{tabular}{lccccccccc}
\hline & W & $\mathbf{L}$ & $\mathbf{T}$ & $\mathbf{W i}$ & $\mathbf{W s}$ & $\mathbf{L / W}$ & $\mathbf{T} / \mathbf{W}$ & $\mathbf{W i} / \mathbf{W}$ & $\mathbf{W s} / \mathbf{W}$ \\
\hline $\mathrm{N}$ & 53 & 53 & 53 & 43 & 30 & 53 & 53 & 43 & 30 \\
Mean value & 9.9 & 7.8 & 5.8 & 7.0 & 6.3 & 1.27 & 0.60 & 0.69 & 0.57 \\
Standard deviation & 2.3508 & 1.6991 & 1.2893 & 2.0649 & 1.2388 & 0.0950 & 0.0543 & 0.0708 & 0.0535 \\
Standard error ( \pm ) & 0.3229 & 0.2334 & 0.3229 & 0.3229 & 0.2262 & 0.0130 & 0.0075 & 0.0107 & 0.010 \\
MIN & 4.5 & 4.0 & 2.5 & 2.4 & 4.1 & 1.07 & 0.50 & 0.54 & 0.44 \\
MAX & 15.3 & 10.9 & 8.5 & 12.8 & 9.3 & 1.46 & 0.72 & 0.88 & 0.66 \\
\hline
\end{tabular}




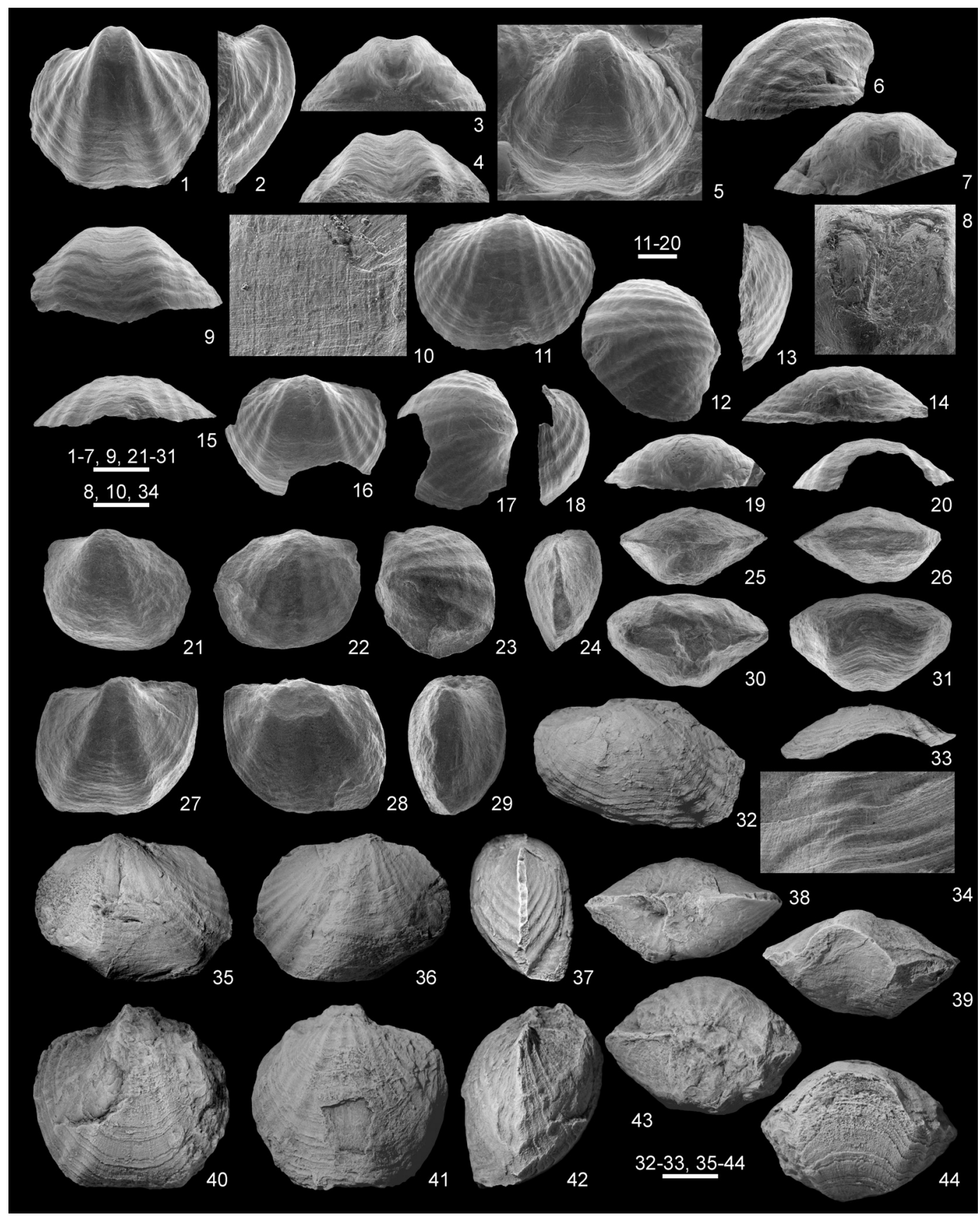

FIGURE 23. Texathyris? tarpata (Schmidt, 1924). 1-20, Rhenish type material from Stockum locality (Acutimitoceras prorsum Zone). 1-4, ventral valve (lectotype, BGR-X5732) in ventral, lateral, posterior and anterior views. 5-10, ventral valve partly embedded in carbonate matrix (associated to BGR-X5731) in ventral, lateral, posterior and anterior (9) views, close-up of the umbonal region showing the median septum (8), and detail of the capillae in the sulcus (10). 1115, almost complete dorsal valve (BGR-X5731) in dorsal, lateral oblique, lateral, posterior and anterior views. 16-20, incomplete dorsal valve (associated to BGR-X5732) in dorsal, lateral oblique, lateral, posterior and anterior views. 2144, Thuringian material from the Pfaffenberg Member (Pfaffenberg-SW). 21-26, almost complete juvenile specimen (MB.B.9898) in ventral, dorsal, lateral oblique, lateral, posterior and anterior views (bed 2). 27-31, almost complete juvenile specimen (MB.B.9899) in ventral, dorsal, lateral, posterior and anterior views (bed 3). 32-33, slightly distorted ventral valve (MB.B.9900) in dorsal and anterior views (bed 3). 34, detail of the microornament of a distorted ventral valve (MB.B.9901) (bed 2SW). 35-39, slightly distorted articulated specimen (MB.B.9902) in ventral, dorsal, lateral, posterior and anterior views (bed 1, nodules). 40-44, almost complete articulated specimen (MB.B.9903) in ventral, dorsal, lateral, posterior and anterior views (bed 1, nodules). Scale bars: 1-7, 9, and 21-31 (2 mm), 11-20 (3.5 mm), 8 $(500 \mu \mathrm{m}), 10(250 \mu \mathrm{m}), 32-33$ and 35-44 $(4 \mathrm{~mm}), 34(1 \mathrm{~mm})$. All SEM, except 32-33, 35-44. 


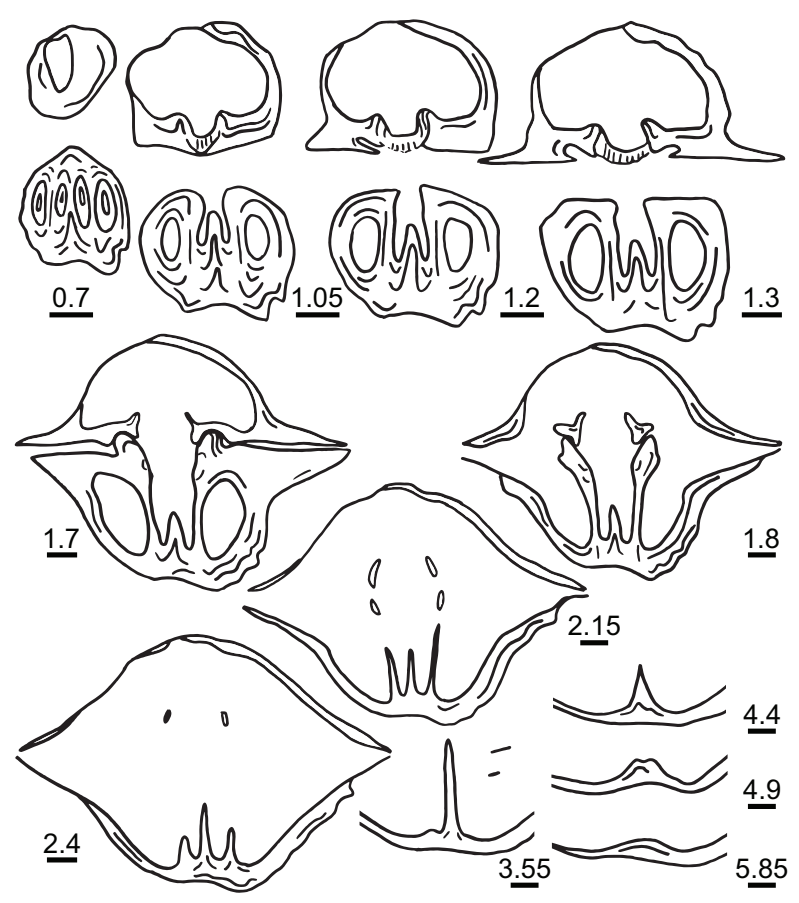

FIGURE 24. Transverse serial sections of Texathyris? tarpata (Schmidt, 1924) from the Pfaffenberg Member (Fischersdorf-Gositzfelsen, bed 1, nodules) (MB.B.9904). Numbers refer to distances in $\mathrm{mm}$ from the tip of the ventral umbo. Scale bars: $1 \mathrm{~mm}$.

Famennian Clymenia Limestone of the Armorican Massif (western France) to Schmidt's species.

\section{Order TEREBRATULIDA Waagen, 1883 \\ Terebratulide gen. et $\mathrm{sp}$. indet. \\ Figure 4, Figure 25}

Material. Fischersdorf-Gositzfelsen (bed 22.7-12): one almost complete articulated shell.

Remarks. This small, dorsibiconvex, and longer than wide shell is characterized by the following features: widest at mid-length; anterior commissure bisulcate; five rounded ribs on ventral and four on dorsal valves inconspicuously arising in anterior part of each valve; thin microlines present. The broken ventral valve shows dental plates delimiting a large central apical cavity and two small lateral ones (Figure 25.6). The lack of data related to the dorsal morphology precludes a generic and specific identification.

Occurrence. Gleitsch Formation, Breternitz Member (do VI) (Figures 4, 26).

\section{STRATIGRAPHIC SUMMARY}

The stratigraphic range of the brachiopods recognized within the Gleitsch Formation (Breter- nitz and Pfaffenberg members only), which is exposed in several sections southeast of Saalfeld (Thuringia) (Figures 1, 2.1), is summarized in Figure 26 . For the detailed distribution, the reader is referred to Figures 4 and 5 as well as to the bed numbers included in the paragraphs devoted to the material available for each species. No brachiopods occur in the Obernitz Member $(8 \mathrm{~m}$ of siltstones and turbiditic quartzites, representing an extremely short time interval, obviously shorter than one ammonoid or conodont biozone of $0.2-$ $0.4 \mathrm{Ma}$ ).

As previously stated, brachiopods are particularly scarce in the top Famennian and basal Hastarian succession developed on the northeastern flank of the Berga Anticline (Figures 1-3). Their poor preservation prevents a detailed systematic study. The Kapfenberg Member exposed at the Buschteich quarry yielded "Lingularia" sp. indet. (do $\mathrm{VI}$ ), chonetidine gen. indet. (do $\mathrm{V}$, do $\mathrm{VI}$ ), productidine gen. indet. (do V), Rozmanaria? sp. indet. (do V, do VI) and Crurithyris? sp. (do V). There, the Löhma Member includes Oehlertella? sp., Productina sp., athyridide? gen. et sp. indet., Cleiothyridina cf. pfaffenbergensis sp. nov., and Crurithyris? sp. The following species are reported from the Kahlleite quarry (Löhma Member): Productina saalfeldensis sp. nov., Cleiothyridina pfaffenbergensis sp. nov., and Crassumbo germanicus sp. nov.

\section{PALAEOECOLOGY AND TAPHONOMY}

The mixed siliciclastic-carbonate Gleitsch Formation (upper Famennian-Tournaisian) corresponds to a basinal facies of entomozoid ostracode shales (Cypridinenschiefer), interrupted by occurrences of regressive siltstone and turbiditic quartzitic sandstone sequences less than $10 \mathrm{~m}$ thick, corresponding to the Reschwitz and Obernitz members (Weyer, 1979; Bartzsch and Weyer, 2012) (Figures 3-5). The shales include numerous early diagenetic nodules whereas the biomicritic limestones correspond to biomicrites with a certain amount of clay (Weyer, 1979). The environment was generally quiet with some periods of agitation and bottom currents, reflected notably by the presence of millimetric silty and sandy layers, crinoidal lenses and accumulations of dissociated valves of posidoniid bivalves (Guerichia) and fragments of trilobites (Weyer, 1979). The fauna is diverse and besides the brachiopods described above, it includes numerous pelagic (placoderms, ammonoids, nautiloids, posidoniid bivalves, conodonts, entomozoid ostracods) and benthic (e.g., 


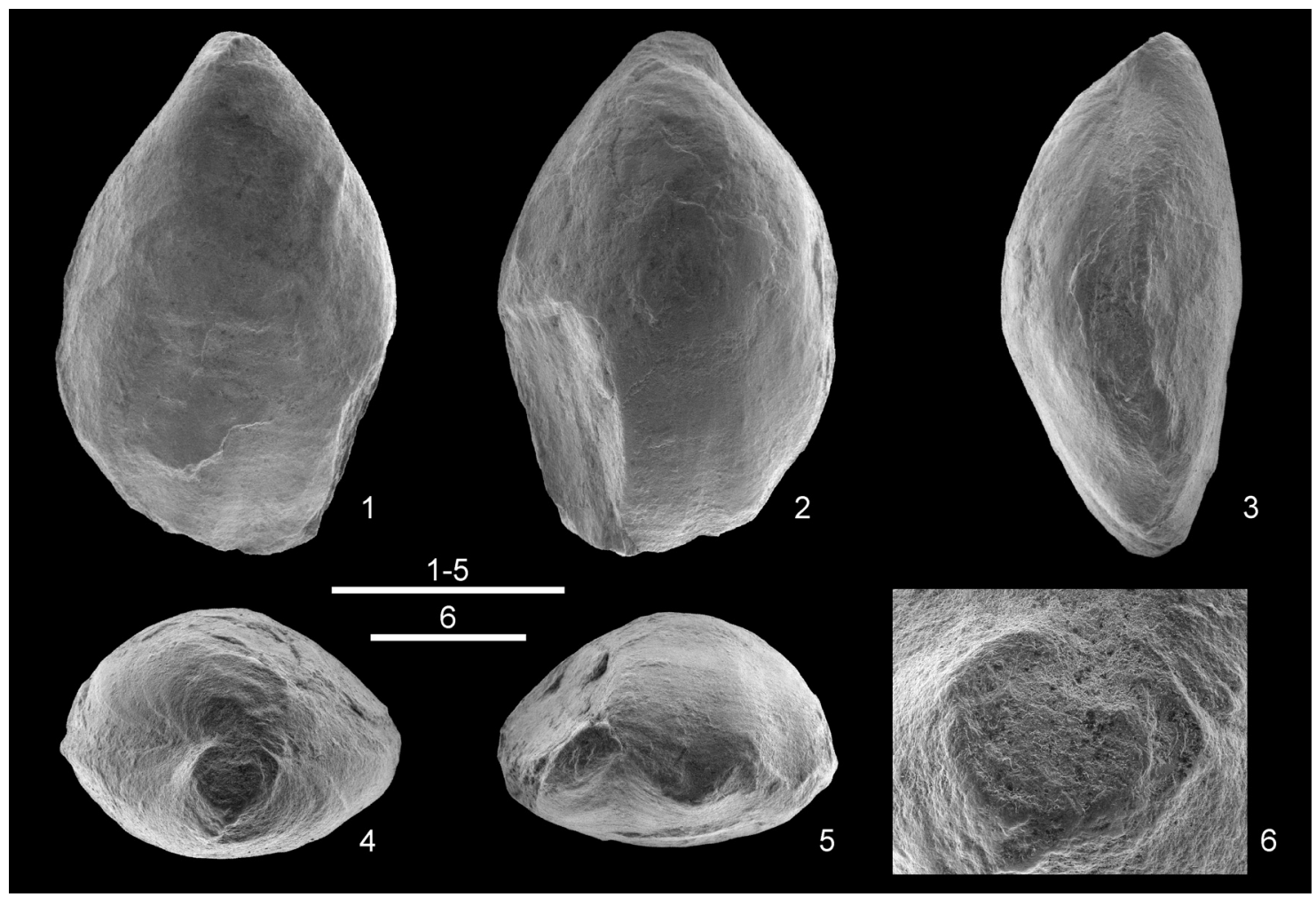

FIGURE 25. Terebratulide gen. et sp. indet. from the Breternitz Member, Fischersdorf-Gositzfelsen (bed 22.7-12, do $\mathrm{VI}$ ), articulated specimen (MB.B.9905) in ventral, dorsal, lateral, posterior and anterior views and detail of the ventral umbo showing dental plates and apical cavities. Scale bars: $1-5(5 \mathrm{~mm})$ and $6(1 \mathrm{~mm})$. All SEM.

crinoids, gastropods, bivalves, solitary rugose corals, tabulate corals, trilobites, psychrospheric ostracods of Thuringian ecotype, bryozoans, foraminifera) organisms (see references in Bartzsch et al., 1998; Bartzsch and Weyer, 2012). Deep-water conditions are thus reflected by the cephalopods (clymeniids and goniatites) and blind trilobites (Weyer, 1979). Burrows of ichnofossils, which are normally completely destroyed by compaction of argillaceous sediments, are preserved in the limestone nodules of early diagenetic origin or preserved in shale by pyrite infiltration (e.g., Bartzsch et al., 1998). The summit of the Breternitz Member (beds 27.8-30.9; Figure 4 and Kononova and Weyer, 2013: figure 7b-o) would be characterized by a regression as reflected by the presence of the ostracod genus Tetrasacculus according to Blumenstengel's $(1994,1997)$ interpretation. After the deposition of the Obernitz Member, reflecting a short regressive sequence (Bartzsch and Weyer, 1986; Bartzsch et al., 1999, 2015), the Pfaffenberg Member is interpreted as a deepening-upward sequence that culminated with the Rußschiefer Formation.
Ten brachiopod species occurring within the Breternitz Member have been recorded so far, but this number is slightly underestimated as some poorly preserved specimens remain difficult to identify. Spire-bearing brachiopods (Athyridida, Spiriferida) are very scarce (three specimens!). Small- to medium-sized, poorly ornamented, thinshelled, and uniplicate or unisulcate rhynchonellides (Rozmanaria, Hadyrhyncha, Novaplatirostrum, rozmanariid? gen. indet.) represent $40 \%$ of this assemblage with Novaplatirostrum cf. fibrosissimum as the predominant species. These rhynchonellides belong to the superfamily Pugnacoidea, of which representatives rank among the most common elements of DevonianCarboniferous dysaerobic environments (e.g., Bowen et al., 1974; Biernat and Racki, 1986a; Racki, 1989; Alexander, 1994; Sartenaer et al., 1998; Mottequin and Legrand-Blain, 2010; Mottequin et al., 2015a). Palaeobiological implications of the co-occurrence of uniplicate and unisulcate rhynchonellides in Polish contemporaneous succession was discussed by Halamski and Baliński (2009). In contrast with the situation observed in the Breternitz Member, the Tournaisian brachiopod 


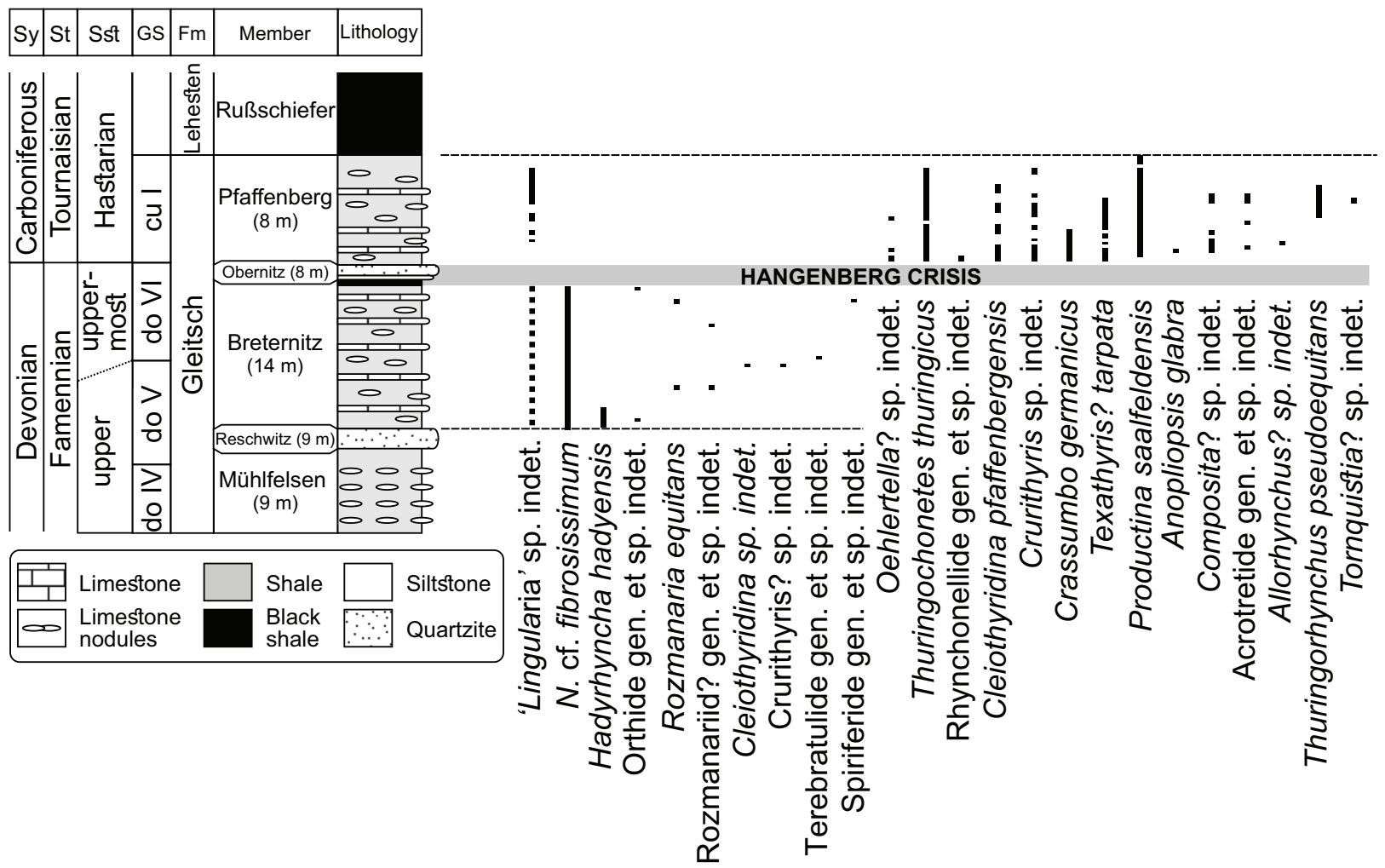

FIGURE 26. Distribution of the brachiopods within the Gleitsch Formation (Breternitz and Pfaffenberg members; modified from Bartzsch et al., 2008) in the Saalfeld area (SE Thuringia), on both sides of the Devonian-Carboniferous boundary. The range of Anopliopsis glabra and Thuringochonetes thuringicus is based on Afanasjeva (2002). Abbreviations: Fm, formation; GS, German "Stufe"; N., Novaplatirostrum; Sst, substage; St, stage; Sy, system.

fauna recognized in the Pfaffenberg Member is more diverse (at least 15 species) and dominated by productides (Chonetidina and Productidina) and spiriferides, which represent almost $50 \%$ of the whole assemblage. In terms of number of specimens, Productina saalfeldensis sp. nov. is by far the most common species. Rhynchonellides are clearly less diverse and less abundant here, although the pugnacid Thuringorhynchus pseudoequitans gen. et sp. nov. occurs in a relative abundance within the bed $6 \delta$ in the locality PfaffenbergNE (Figures 2.1, 5). Only P. saalfeldensis sp. nov. is still present in the bed $10 \mathrm{y}$ but no suitable outcrops to collect fossils above this bed are available; limestones nodules are nearly absent or strongly weathered. The Rußschiefer Formation (Figure 3) includes black shales (crenulata Event) with phosphatic nodules rich in radiolarians, but yields only some rare ammonoids.

Within the Pfaffenberg Member, the degree of articulation of the rhynchonellides and the spirebearers (Athyridida, Spiriferida), which all possess strong articulatory processes, is high in compari- son with the productides which are essentially represented by dissociated valves. No articulated lingulids were recovered; according to Emig (1986), their preservation as single valves reflects the influences of environmental changes (salinity, influx of coarse sedimentary particles, storm) that induced their death and thus the exit from their burrow. Delicate shelly structures, such as the hinge spines in the chonetidines Thuringochonetes thuringicus (see Afanasjeva, 2002, plate 4, figures 5-6) and Tornquistia? sp. indet. (Figure 7.10), are sometimes preserved. All these observations strongly suggest that the brachiopod assemblage recognized in the Pfaffenberg Member represents an autochthonous one as is also the case for the assemblage recorded in the Breternitz Member where the great majority of the rhynchonellides is articulated.

One of the striking features of the brachiopod faunas recognized in this part of Thuringia is the minute or small size of numerous species. It is especially true for those of the Pfaffenberg Member in which the largest sizes are reached by Thur- 


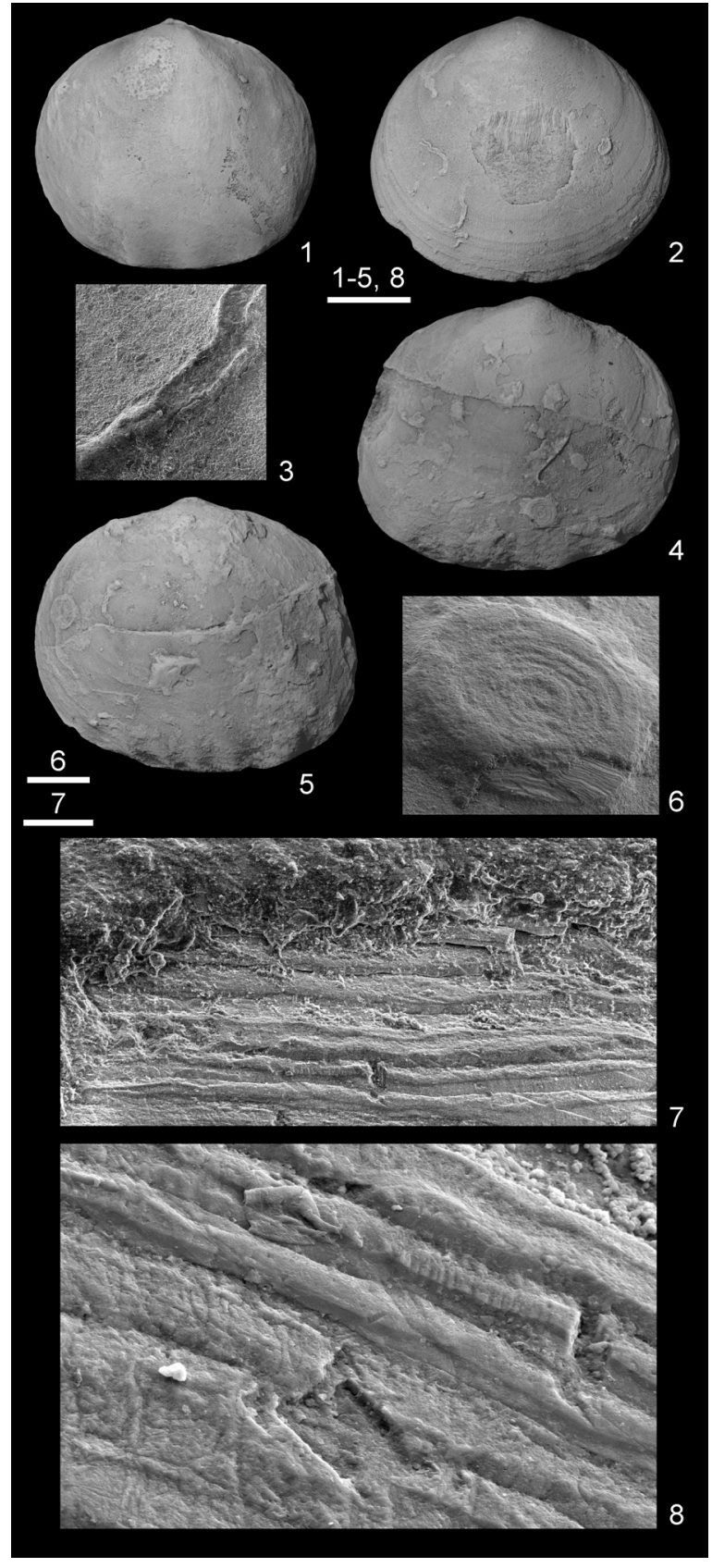

FIGURE 27. Novaplatirostrum cf. fibrosissimum (Tietze, 1870) with epizoans. 1, dorsal view of an articulated specimen (MB.B.9906) with a bryozoan colony in its posterior part (Fischersdorf-Gositzfelsen, beds 22.7-12, do VI). 2-3, dorsal view of an articulated specimen (MB.B.9907) with unidentified tube-worm epizoans and close-up of one of them (Fischersdorf-Gositzfelsen, bed 11.2-5, do V). 4-8, articulated specimen (MB.B.9908), partly coated with gold, in ventral and dorsal views with enigmatic circular epizoans, close-up of that attached to ventral valve and detail of the structure of its shell (Fischersdorf-Gositzfelsen, beds 22.7-12, do VI). Scale bars: 12 and $4-5(5 \mathrm{~mm}), 3$ and $6(500 \mu \mathrm{m}), 7(50 \mu \mathrm{m})$, and $8(25$ $\mu \mathrm{m})$. All SEM, except 1-2, 4-5. ingorhynchus pseudoequitans gen. et sp. nov. and Texathyris? tarpata. Several species belong to genera, which also occur in ramp and/or platform settings, where their representatives generally reach a larger size (e.g., Productina, Cleiothyridina), but micromorphic brachiopods occur also in shallow environments (e.g., Alexander, 1977; Mottequin et al., 2015b). Based on Pérez-Huerta and Sheldon (2006) discussion, the nutrient availability, the depth and the water oxygenation are most probably the biotic and physicochemical factors that played the most important roles in controlling the size of brachiopods in the Thuringian deep-water environments. According to PérezHuerta and Sheldon (2006), the productides would be larger than spire-bearers (Athyridida, Spiriferida) and dominant in food-depleted environments, but this is not really matched in the present case concerning the size of the brachiopods, but it is evident that productides are particularly abundant. It is also worthwhile to stress the fact that the Hastarian brachiopods recognized in Thuringia do not reach the size of the largest rhynchonellides known from the Famennian Breternitz Member (Hadyrhyncha and Novaplatirostrum). This could be related to more stressful conditions during the first stages of the post-Hangenberg recovery. As the Pfaffenberg Member would correspond to a deepening-upward sequence, the small size of the brachiopods could be explained by the necessity for these organisms to reproduce as soon as possible in a relatively hostile environment and thus may involve heterochronic processes.

Encrustation by epizoans are particularly scarce. Only specimens of Novaplatirostrum cf. fibrosissimum from the Breternitz Member, that can be counted on the fingers of one hand, show encrustations by bryozoans (Figure 27.1) and worm-tube organisms (Figure 27.2-3). Rare encrustations of arenaceous foraminifers also occur; as with bryozoans, they could have been also postmortal, using the dead brachiopod shell as hardground. Encrusting Aulopora (tabulates) has never been observed. On one specimen of Novaplatirostrum cf. fibrosissimum two circular epizoans with clearly concentric structures have been discovered (Figure 27.4-8). This kind of epizoan does not belong to a group of corals and cannot represent the holdfast of an echinoderm (G. Sevastopulo, personal communication, 2017). One of these epizoans has its shell slightly broken on one side, which reveals its detailed constitution. It is formed of superimposed mineralized layers of very regular thickness, composed of $\mathrm{CaCO}_{3}$ (no trace of 
phosphorous) as shown by qualitative EDS-analysis. The question of its attribution to phylum Mollusca arose insofar as fossil encrusting bivalves are known from several geological formations (Atreta for instance). Nonetheless, the concentric structure does not reveal traces of muscular scars or any particular spot that might suggest the existence of a possible hinge. We have therefore rejected this hypothesis and the possibility of belonging to a group of linguliform brachiopods, and more precisely to be the ventral valve of a Discinoidea. This particular group has a shell whose fabric is typically baculate. Baculi are apatitic structure included in a crossed network inside an organic matrix. Large magnifications using the SEM were not able to put such a structure in evidence. In some places parallel crystalline prisms were observed, but they are never separated by a different material of cementation: they are merely contiguous. The assignment to the Discinoidea is thus rejected as also suggested by the calcitic composition of the shell. These concentric structures resemble the circular holdfasts of Sphenothallus attached to brachiopods that were illustrated by Neal and Hannibal (2000), but they cannot be assigned to this genus, which corresponds to chitonous or phosphatic tubes (Neal and Hannibal, 2000; Wei-Haas et al., 2011). This epizoan is therefore considered temporarily as an incertae sedis pending a plausible interpretation.

No drill holes or pedicle boring traces were observed in the investigated Material. One articulated shell of Cleiothyridina pfaffenbergensis sp. nov. (Figure 16.6-11) displays symmetrically arranged damage along its lateral margins, probably resulting from the bite of a predator ("fish"?). This bite was not lethal as reflected by the distortion of the shell outline and the deviation of the concentric ornamentation.

\section{BRACHIOPOD CHANGES AT THE DEVONIAN- CARBONIFEROUS BOUNDARY}

Although the criteria used for the definition of the Devonian-Carboniferous is now the focus of an international working group (Becker et al., 2016), this boundary is still defined by the incoming of the supposed first Siphonodella (Eosiphonodella) sulcata at La Serre (Global Stratotype Section and Point) in Montagne Noire (southern France) (Paproth et al., 1991). In Thuringia, the brachiopod assemblages from the Beternitz and the Pfaffenberg members display strong differences in their composition (see above). The fact that the brachiopod turnover took place within the Protognathodus kockeli conodont Zone, so below the current Devonian-Carboniferous boundary (Figures 5, 26), promotes the use of another criterion to define this boundary. From this viewpoint, during the International Workshop of the joined Subcommissions on Devonian and Carboniferous Stratigraphy task group (Montpellier, September 2016), it was proposed to use the base of the $P$. kockeli Zone, the beginning of radiation, the top of major regression (top of the Rhenish Hangenberg Sandstone and its regional equivalents) and the end of the mass extinction as potential boundary horizon and criterion for the redefinition of the base of the Carboniferous (Spalletta et al., 2017).

Among the rhynchonelliform brachiopods, none of the species recognized in the Breternitz Member survive to the Hangenberg Crisis (Figure 26) unless the conspecificity of Crurithyris sp. indet. and C.? sp. indet. is demonstrated in the future (see discussion above). The last brachiopods (orthide gen. et sp. indet.) from the Breternitz Member are known from the top of this lithostratigraphic unit (bed 32.11), so just below an anoxic black shale horizon (bed 32.12) interpreted as the first episode of the Hangenberg Crisis (Bartzsch et al., 1998; Bartzsch and Weyer, 2012) and equivalent to the Rhenish Hangenberg Black Shale (Figure 4). The Obernitz Member, which corresponds to the Rhenish Hangenberg Shale and Sandstone (Bartzsch et al., 2015), is devoid of brachiopods. The lack of data related to the linguliform species ("Lingularia" sp. indet.) does not permit to affirm (or otherwise) if the Famennian and Tournaisian forms are conspecific (see above). Brachiopods thus underline the drastic synchronous extinction and faunal change at the Devonian-Carboniferous boundary (Hangenberg Crisis), already well known from nearly all other invertebrate groups (Ammonoidea, Trilobita, Ostracoda, Anthozoa) and conodonts. They disprove the opposite opinion of Schindewolf (1928, p. 654) about a cascade boundary: corals, brachiopods, trilobites and ammonoids should have their critical faunal changes at different stratigraphical levels. This error had arisen not only from the restricted knowledge of his times (especially for Rugosa), but also from neglecting facial differentiation (mixing of photic and aphotic communities).

The brachiopod fauna from the Pfaffenberg Member includes representatives of pre-existing genera known from Famennian strata (e.g., Cleiothyridina, Composita) and of new ones (e.g., Thuringorhynchus gen. nov., Crassumbo). Members of the family Rozmanariidae, which were particularly 
well-represented during the Famennian and especially in Thuringia, do not cross the Devonian-Carboniferous boundary (Mottequin et al., 2014). Kaiser et al. (2016) proposed a so-called Rozmanaria post-crisis fauna on the basis of Bartzsch et al.'s (2015) report of Rozmanaria? nov. sp. [= Rozmanaria equitans (Schmidt, 1924) in Bartzsch and Weyer, 1986] within the Pfaffenberg Member, but this terminology has to be rejected definitely. These so-called Tournaisian Rozmanaria belong to the genus Thuringorhynchus gen. nov. (see above) and only represent a small part of the brachiopod fauna from the Pfaffenberg Member. Furthermore, it appears that another genus, yet to be defined, was confused with Rozmanaria by Weyer (1972). This genus temporarily identified here as rozmanariid? gen. indet. (see above) is recognized in do VI succession of the Rhenish and Thuringian Slate Mountains and is thus probably useful for biostratigraphic purposes. The brachiopod assemblage recorded in the first bed of the Pfaffenberg Member (Protognathodus kockeli Zone, in the past identified as Upper Siphonodella praesulcata Zone) already includes seven species whereas the peak of diversity is reached in bed 3 with nine species (Figure 5). After this peak, the number of species tends to decrease progressively and perhaps reaches a nadir (only one species) within bed 10 (Figure 5), though this is only very poorly fossiliferous. It clearly appears that the basal Hastarian aphotic environments were colonized by a more diverse brachiopod panel than previously because of the drastic decline of the rhynchonellides which were yet so abundant during the Late Devonian.

The occurrence of a single terebratulide within the upper part of the Breternitz Member (do VI) is remarkable as they are not common and diverse during the Famennian, in which García-Alcalde (in Brice et al., 2000) reported four long-ranging genera, which were all known before this stage. In Europe, they were reported at least in the middle Famennian of the Holy Cross Mountains of Poland (Biernat and Racki, 1986a) but are absent there from the top of the Famennian (Halamski and Baliński, 2009). They seem to be unrecorded in the upper and uppermost Famennian shallower deposits like in the Franco-Belgian Basin (Dehée, 1929; Mottequin and Brice, 2016) or in the Cantabrian Mountains in Spain (García-Alcalde, 1996). The record of terebratulides by Dantz (1893) (see also Paul, 1937) within (at least) the upper Famennian of the Aachen area (Germany), which corresponds to the eastern extension of the Franco-Belgian Basin, needs to be confirmed.

\section{PERSPECTIVES}

This study of the brachiopod faunas, which colonized the deep-water environments from Thuringia (Saalfeld area) at the end of the Devonian and during the early Carboniferous, needs to be complemented in the future by the investigation of those occurring in similar facies as exposed in the numerous sections of the Rhenish Slate Massif (Germany). It will permit to refine our understanding of the processes responsible for the Hangenberg Crisis at the end of the Devonian within the deep-water settings of this part of Laurussia. Investigation of contemporaneous brachiopod faunas from North Africa, where similar facies are particularly well-developed, is also required as most of the studies are focused only on the rhynchonellides. Last but not least, the thorough revision of the contemporaneous brachiopod faunas from shallower (Strunian), mixed siliciclastic-carbonate environments described notably by Paeckelmann (1930, 1931), Gallwitz (1932) and Paul (1939) is urgently needed.

\section{ACKNOWLEDGEMENTS}

†E. Simon passed away suddenly on 11 February 2018 after a career dedicated to teaching of biochemistry and microbiology in higher education institutions until his retirement in 2013. In the meantime he developed an acknowledged expertise in Cretaceous and Recent brachiopods. His scientific open-mindedness, his convivial attitude and stimulating friendship will be deeply missed.

The SEM images of the brachiopods were taken at the Royal Belgian Institute of natural Sciences at Brussels by J. Cillis, who also performed the EDS-analysis. A. Ehling and W. Werner are thanked for the loan of the material curated at the Berlin Department of the Bundesanstalt für Geologie und Rohstoffe and at the Bayerische Staatsammlung Paläontologie (München), respectively. G. Sevastopulo is thanked for commenting on some particular traces observed on a rhynchonellide shell. The manuscript benefited from the reviews of an anonymous reviewer and L. Qiao (Nanjing Institute of Geology and Palaeontology), and of the editorial help of K. Claeson (Philadelphia College of Osteopathic Medicine). 


\section{REFERENCES}

Afanasjeva, G.A. 2002. Brachiopods of the Order Chonetida from the basin facies of the Devonian-Carboniferous transitional strata of the Thuringian and Rhenish Slate Mountains (Germany). Paleontologicheskii Zhurnal, 2002(6):57-62. (In Russian)

Alexander, R.R. 1977. Growth, morphology and ecology of Paleozoic and Mesozoic opportunistic species of brachiopods from Idaho-Utah. Journal of Paleontology, 51:11331149.

Alexander, R.R. 1994. Distribution of pedicle boring traces and the life habits of Late Paleozoic leiorhynchid brachiopods from dysoxic habitats. Lethaia, 27:227-234. https://doi.org/10.1111/ j.1502-3931.1994.tb01414.x

Alvarez, F. and Rong, J.-Y. 2002. Athyridida, p. 1475-1601. In Kaesler, R.L. (ed.), Treatise on Invertebrate Paleontology, Part H, Brachiopoda. 4 (revised). Geological Society of America, Boulder, and University of Kansas Press, Lawrence, 1-3226.

Alvarez, F., Rong, J.-Y., and Boucot, A.J. 1998. The classification of athyridid brachiopods. Journal of Paleontology, 72:827-855. https://doi.org/10.1017/s0022336000027189

Bartzsch, K., Blumenstengel, H., Gereke, M., Schindler, E., Weyer, D., and Ziegler, W. 2001. Postconference field trip (N, part 1): Thüringer Schiefergebirge, p. 87-113. In Jansen, U., Königshof, P., Plodowski, G., and Schindler, E. (eds.), Field Trips Guidebook. $-15^{\text {th }}$ International Senckenberg Conference May 11-21, 2001 "Mid-Palaeozoic Bio- and Geodynamics, The North Gondwana-Laurussia Interaction," Joint Meeting International Geological Correlation Programme (IGCP), No. 421 and Subcommission on Devonian Stratigraphy (SDS). Senckenberg, Frankfurt/Main.

Bartzsch, K., Blumenstengel, H., and Weyer, D. 1993. Field Excursion Saalfeld 31 July-3 August 1993 to the Palaeozoic (Devonian) of Thuringia. Guidebook. Göttingen Meeting 31 July-6 August 1993 (Gross symposium), IGCP Project 328 Palaeozoic Microvertebrates. Subcommission on Devonian Stratigraphy, Göttingen.

Bartzsch, K., Blumenstengel, H., and Weyer, D. 1999. Stratigraphie des Oberdevons im Thüringischen Schiefergebirge. Teil 1: Schwarzburg-Antiklinorium. Beiträge zur Geologie von Thüringen, Neue Folge, 6:159-189.

Bartzsch, K., Blumenstengel, H., and Weyer, D. 2001. Stratigraphie des Oberdevons im Thüringischen Schiefergebirge. Teil 2: Berga-Antiklinorium. Beiträge zur Geologie von Thüringen, Neue Folge, 8:303-327.

Bartzsch, K., Blumenstengel, H., and Weyer, D. 2008. Oberdevon des Thüringischen Schiefergebirges. Schriftenreihe der Deutschen Gesellschaft für Geowissenschaften, 52:5987.

Bartzsch, K., Gaitzsch, B., Abel, P., Hahne, K., and Weyer, D. 2015. Oberdevon und Unterkarbon im Raum Saalfeld. Exkursions Führer, Subkommissionen Devon und Karbon der Deutschen Stratigraphischen Kommission. Saalfeld, 23.04 bis 25.04.2015. Published by the authors, Saalfeld.

Bartzsch, K., Hahne, K., and Weyer, D. 1998. Der Hangenberg-Event (Devon/Karbon-Grenze) im Bohlen-Profil von Saalfeld (Thüringisches Schiefergebirge). Abhandlungen und Berichte für Naturkunde (Museum für Naturkunde Magdeburg), 20:37-58.

Bartzsch, K. and Weyer, D. 1982. Zur Stratigraphie des Untertournai (Gattendorfia-Stufe) von Saalfeld im Thüringischen Schiefergebirge. Abhandlungen und Berichte für Naturkunde (Museum für Naturkunde Magdeburg), 20:3-54.

Bartzsch, K. and Weyer, D. 1986. Biostratigraphie der Devon/Karbon-Grenze im Bohlen-Profil bei Saalfeld (Thüringen, DDR). Zeitschrift für Geologische Wissenschaften, 14:147-152.

Bartzsch, K. and Weyer, D. 1988. Neue Gattenpleura-Funde aus dem Unter-Tournai des Saxothuringikums (Ammonoidea, Unterkarbon). Hallesches Jahrbuch für Geowissenschaften, 13:37-48.

Bartzsch, K. and Weyer, D. 1996. Acutimitoceras acutum (Schindewolf 1923)-Leitart der ersten unterkarbonischen Ammonoidea-Zone im Bohlen-Profil von Saalfeld (Thüringisches Schiefergebirge). Beiträge zur Geologie von Thüringen (Weimar, Jena), Neue Folge, 3 (Festschrift zum 65. Geburtstag von Prof. Dr. Harald Lützner):91-103. 
Bartzsch, K. and Weyer, D. 2012. Zur Stratigraphie des Breternitz-Members (Obere ClymenienSchichten, Oberdevon) von Saalfeld (Schwarzburg-Antiklinorium, Thüringisches Schiefergebirge). Freiberger Forschungshefte, Reihe C, 542:1-54.

Bassett, M.G. and Bryant, C. 2006. A Tournaisian brachiopod fauna from south-east Wales. Palaeontology, 49:485-535. https://doi.org/10.1111/j.1475-4983.2006.00551.x

Becker, G. and Blumenstengel, H. 1995. The importance of the Hangenberg event on ostracod distribution at the Devonian/Carboniferous boundary in the Thuringian and Rhenish Schiefergebirge, p. 26-30. In Riha, J. (ed.), Ostracoda and Biostratigraphy. Proceedings of the $12^{\text {th }}$ International Symposium on Ostracoda Prague (Czech Republic) July 1994. A.A. Balkema, Rotterdam.

Becker, R.T. 1988. Ammonoids from the Devonian-Carboniferous Boundary in the Hasselbach Valley (Northern Rhenish Slate Mountains). Courier Forschungsinstitut Senckenberg, 100:193-213.

Becker, R.T. 1996. New faunal records and holostratigraphic correlation of the Hasselbachtal D/ C-boundary auxiliary stratotype (Germany). Annales de la Société Géologique de Belgique, 117:19-45.

Becker, R.T., Kaiser, S.I., and Aretz, M. 2016. Review of chrono-, litho- and biostratigraphy across the global Hangenberg Crisis and Devonian-Carboniferous Boundary. Geological Society London Special Publications, 423:355-386. https://doi.org/10.1144/sp423.10

Biernat, G. 1983. On the Famennian brachiopods from Jabłonna, Góry Świętokrzyskie Mts., Poland. Biuletyn Instytutu Geologicznego, 345:137-154.

Biernat, G. 1988. Famennian Brachiopods of the Holy Cross Mountains, Poland, p. 327-335. In McMillan, N.J., Embry, A.F., and Glass, D.F. (eds.), Devonian of the world (Proceedings of the $2^{\text {nd }}$ international symposium on the Devonian System, Calgary), 3. Memoirs of the Canadian Society of Petroleum Geologists, 14.

Biernat, G. and Emig C.C. 1993. Anatomical distinctions of the Mesozoic lingulide brachiopods. Acta Palaeontologica Polonica, 38:1-20.

Biernat, G. and Racki, G. 1986a. A rhynchonellid-dominated late Famennian brachiopod assemblage from the Holy Cross Mountains (Poland). Acta Palaeontologica Polonica, 31:85109.

Biernat, G. and Racki, G. 1986b. Some aspects of sulcation within the smooth Famennian rhynchonellids from Poland, p. 47-54. In Rachebœuf, P.R. and Emig, C.C. (eds.), Les brachiopodes fossiles et actuels. Actes du 1er congrès international sur les Brachiopodes, Brest 1985. Biostratigraphie du Paléozoïque, 4.

Bischoff, G. 1957. Die Conodonten-Stratigraphie des rheno-herzynischen Unterkarbons mit Berücksichtigung der Wocklumeria-Stufe und der Devon/Karbon-Grenze. Abhandlungen des Hessischen Landesamtes für Bodenforschung, 19:1-64.

Bitner, M.A. and Emig, C.C. 2016. On the type species of Lingularia, and description of Eolingularia n. gen. Carnet de Géologie, 16:543-555. https://doi.org/10.4267/2042/56006

Blumenstengel, H. 1959. Über oberdevonische Ostracoden und ihre stratigraphische Verbreitung im Gebiet zwischen Saalfeld und dem Kamm des Thüringer Waldes. Freiberger Forschungshefte, Reihe C, 72:53-107.

Blumenstengel, H. 1965. Zur Taxionomie und Biostratigraphie verkieselter Ostracoden aus dem Thüringer Oberdevon. Freiberger Forschungshefte, Reihe C, 183:1-127.

Blumenstengel, H. 1979. Die Ostracodenfauna der Wocklumeria-Stufe (Oberdevon) bei Saalfeld im Thüringer Schiefergebirge. Zeitschrift für geologische Wissenschaften, 7(4):521-557.

Blumenstengel, H. 1994. Zur Bedeutung von Meeresspiegelschwankungen bei der Bildung der Oberdevonsedimente von Saalfeld, Thüringer Schiefergebirge. Geowissenschaftliche Mitteilungen von Thüringen, 2:29-44.

Blumenstengel, H. 1997. Eine neue Zonengliederung der Oberen Clymenien-Schichten (Famennium) von Saalfeld nach Ostracoden des Thüringer Ökotyps. Beiträge zur Geologie von Thüringen, Neue Folge, 4:19-36.

Blumenstengel, H. and Gräbe, R. 1969. Zur Fazies des Oberdevons und Unterkarbons (Dinants) in der Bohrung Oschitz 11 bei Schleiz (NW-Rand des Bergaer Sattels, Ostthüringen). Jahrbuch für Geologie, 2 (for 1966):501-520 (dated 1968).

Bockwinkel, J. and Ebbighausen, V. 2006. A new ammonoid fauna from the GattendorfiaEocanites Genozone of the Anti-Atlas (Early Carboniferous; Morocco). Fossil Record, Mitteilungen aus dem Museum für Naturkunde in Berlin, 9:87-129. https://doi.org/10.5194/fr9-87-2006 
Boucot, A.J. 1959. Brachiopods of the Lower Devonian rocks at Highlands Mills, New York. Journal of Paleontology, 33:727-769.

Boucot, A.J., Johnson, J.G., and Staton, R.D. 1964. On some atrypoid, retzioid, and athyridoid Brachiopoda. Journal of Paleontology, 38:805-822.

Bowen, Z.P., Rhoads, D.C., and McAlester, A.L. 1974. Marine benthic communities in the Upper Devonian of New York. Lethaia, 7:93-120. https://doi.org/10.1111/j.15023931.1974.tb00889.x

Brand, P.J. 1970. Scottish Carboniferous chonetoids. Bulletin of the Geological Survey of Great Britain, 31:89-137.

Branson, E.B. and Mehl, M.G. 1934. Conodonts from the Bushberg sandstone and equivalent formations of Missouri. The University of Missouri Studies, 8(4):265-299, 335-338.

Branson, E.R. 1934. Conodonts from the Hannibal formation of Missouri. The University of Missouri Studies, 8(4):301-334, 338-343.

Brice, D., Carls, P., Cocks, L.R.M., Copper, P., García-Alcalde, J.L., Godefroid, J., and Rachebœuf, P.R. 2000. Brachiopoda. Courier Forschungsinstitut Senckenberg, 220:65-86.

Bronn, H.G. 1862. Die Klassen und Ordnungen der Weichthiere (Malacozoa) wissenschaftlich dargestellt in Wort und Bild, Vol. 3, Part 1. C.F. Winter'sche Verlagshandlung, Leipzig and Heidelberg. https://doi.org/10.5962/bhl.title.13389

Brown, T. 1845. Illustrations of the Fossil Conchology of Great Britain and Ireland, with Descriptions and Localities of All the Species, Parts 24-28. Maclachlan and Stuwart, Smith, Elder. Edinburgh \& London. https://doi.org/10.5962/bhl.title.133886

Brunton, C.H.C. 1984. Silicified brachiopods from the Viséan of County Fermanagh, Ireland (III). Rhynchonellids, spiriferids and terebratulids. Bulletin of the British Museum (Natural History), Geology, 38:27-130.

Brunton, C.H.C., Lazarev, S.S., Grant, R.E., and Jin, Y.-G. 2000. Productidina, p. 424-565. In Kaesler, R.L. (ed.), Treatise on Invertebrate Paleontology, Part H (Revised), Brachiopoda, 3. Geological Society of America and University of Kansas Press, Boulder, Colorado, and Lawrence, Kansas, 1-3226.

Brunton, C.H.C. and Mundy, D.J.C. (with appendix by Lazarev, S.S.) 1993. Productellid and plicatiferid (productoid) brachiopods from the Lower Carboniferous of the Craven Reef Belt, North Yorkshire. Bulletin of the Natural History Museum, Geology, 49:99-119.

Buckman, S.S. 1906. Brachiopod nomenclature: Epithyris, Hypothyris, Cleiothyris Phillips, 1841. Annals and Magazine of Natural History (Series 7), 18:321-327. https://doi.org/10.1126/ science.24.623.742

Carter, J.L. 1967. Mississippian brachiopods from the Chappel Limestone of central Texas. Bulletins of American Paleontology, 53:249-488.

Carter, J.L. 1972. Two new genera of lamellose spiriferacean brachiopods. Journal of Paleontology, 46:729-734.

Carter, J.L. 1987. Lower Carboniferous brachiopods from the Banff Formation of western Alberta. Bulletin of Geological Survey of Canada, 378:1-183. https://doi.org/10.4095/122462

Carter, J.L. 1990. Subdivision of the Lower Carboniferous in North America by means of articulate brachiopod generic ranges. Courier Forschungsinstitut Senckenberg, 130:145-155.

Carter, J.L. and Gourvennec, R. 2006. Martinoidea, p. 1747-1768. In Kaesler, R.L. (ed.), Treatise on Invertebrate Paleontology, Part H (Revised), Brachiopoda, 5. Geological Society of America and University of Kansas Press, Boulder, Colorado, and Lawrence, Kansas, 1-3226.

Carter, J.L., Johnson, J.G., Gourvennec, R., and Hou, H.-F. 2006. Spiriferida, p. 1689-1870. In Kaesler, R.L. (ed.), Treatise on Invertebrate Paleontology, Part H (Revised), Brachiopoda, 5. Geological Society of America and University of Kansas Press, Boulder, Colorado, and Lawrence, Kansas, 1-3226.

Chlupáč, I. 1966. The Upper Devonian and Lower Carboniferous Trilobites of the Moravian Karst. Sborník geologických Vĕd, Paleontologie, 7:5-143.

Cooper, G.A. 1955. New genera of middle Paleozoic brachiopods. Journal of Paleontology, 29:45-63.

Cooper, G.A. and Dutro, J.T. Jr. 1982. Devonian brachiopods of New Mexico. Bulletins of American Paleontology, 82-83:1-215.

Cooper, G.A. and Grant, R.E. 1976. Permian brachiopods of west Texas, IV. Smithsonian Contributions to Paleobiology, 21:1923-2607. https://doi.org/10.5479/si.00810266.21.text

Cooper, G.A. and Muir-Wood, H.M. 1951. Brachiopod homonyms. Journal of the Washington Academy of Sciences, 1:195-196. 
Crônier, C., Bartzsch, K., Weyer, D., and Feist, R. 1999. Larval morphology and ontogeny of a Late Devonian phacopid with reduced sight from Thuringia, Germany. Journal of Paleontology, 73:240-255. https://doi.org/10.1017/s0022336000027748

d'Orbigny, A. 1847. Considérations zoologiques et géologiques sur les brachiopodes ou palliobranches, parts 1-2. Comptes Rendus Hebdomadaires des Séances de l'Académie des Sciences (2nd series), 25:193-195, 266-269.

Dagys, A.S. 1974. Triasovye brakhiopody (morfologiya, sistema, filogeniya, stratigraficheskoye znacheniye i biogeografiya. Akademia Nauk SSSR Sibiroskoe Otdelenie Institut Geologii I Geofiziki (IGIG) Trudy, 214:1-386. (In Russian)

Dantz, C. 1893. Der Kohlenkalk der Umgebung von Aachen. Zeitschrift der Deutschen Geologischen Gesellschaft, 45:594-638.

Davidson, T. 1881. On genera and species of spiral-bearing Brachiopoda from specimens developed by the Rev. Norman Glass. Geological Magazine (New Series, Decade 2), 8:1-13. https://doi.org/10.1017/s0016756800112993

Dehée, R. 1929. Description de la faune d'Etrœungt-Faune de passage du Dévonien au Carbonifère. Mémoires de la Société Géologique de France (Nouvelle Série), 5:1-62.

Demanet, F. 1934. Les brachiopodes du Dinantien de la Belgique. Vol. 1, Atremata, Neotremata, Protremata (pars). Mémoires du Musée Royal d'Histoire Naturelle de Belgique, 61:1-116.

Demanet, F. 1958. Contribution à l'étude du Dinantien de la Belgique. Mémoires de l'Institut Royal des Sciences naturelles de Belgique, 141:1-152.

Dorsman, L. 1945. The marine fauna of the Carboniferous in the Netherlands. Mededeelingen van de Geologische Stichting, 3(3):3-101.

Duméril, A.M.C. 1805. Zoologie Analytique ou Méthode Naturelle de Classification des Animaux, Rendue Plus Facile à l'aide de Tableaux Synoptiques. Allais, Paris. https://doi.org/10.5962/ bhl.title.11646

Ebbighausen, V., Bockwinkel, J., Korn, D., and Weyer, D. 2004. Early Tournaisian ammonoids from Timimoun (Gourara, Algeria). Mitteilungen aus dem Museum für Naturkunde in Berlin, Geowissenschaftliche Reihe, 7:133-152. https://doi.org/10.1002/mmng.20040070107

Emig, C.C. 1986. Conditions de fossilisation du genre Lingula (Brachiopoda) et implications paléoécologiques. Palaeogeography, Palaeoclimatology, Palaeoecology, 53:245-253. https:// doi.org/10.1016/0031-0182(86)90061-1

Feist, R. 1992. Trilobiten aus dem Devon/Karbon-Grenzprofil an der Grünen Schneid (Zentrale Karnische Alpen, Österreich). Jahrbuch der Geologischen Bundes-Anstalt, 135:21-47.

Ferguson, J. 1966. Variation in two species of the Carboniferous brachiopod Pleuropugnoides. Proceedings of the Yorkshire Geological Society, 35:353-374. https://doi.org/10.1144/ pygs.35.3.353

Fleming, J. 1828. A History of British Animals, Exhibiting the Descriptive Characters and Systematical Arrangement of the Genera and Species of Quadrupeds, Birds, Reptiles, Fishes, Mollusca, and Radiata of the United Kingdom. Bell and Bradfute and James Duncan, Edinburgh and London. https://doi.org/10.5962/bhl.title.12859

Gallwitz, H. 1932. Die Fauna des deutschen Unterkarbons Die Brachiopoden, 3. Teil. Die Orthiden, Strophomeniden und Choneten des Unteren Unterkarbons (Etrœungt). Abhandlungen der Preussischen Geologischen Landesanstalt, Neue Folge, 141:75-131.

García-Alcalde, J.L. 1996. El Devónico del Dominio Astur-Leonés de la zona Cantábrica ( $\mathrm{N}$ de España). Revista Española de Paleontología, Número extraordinario, 58-71.

Gawlick, K. 1995. Transgressionsgesteuerte Faziesdifferenzierung als Ursache für die adaptive Radiation der Gattung Liobolina (Trilobita) - adaptive Radiation als Schlüssel für die Biostratigraphie (Devon/Karbon, mitteleuropäisches Varistikum), p. 54-55. In Kurzfassungen der Vorträge und Poster. Sediment'95, 10. Sedimentologentreffen 24-28 Mai 1995. TU Bergakademie, Freiberg.

Gawlick, K. 1996. Revision und Stratigraphische Bedeutung der Gattung Liobolina (Trilobita) Unpublished PhD Thesis, Fachbereich Geowissenschaften, Phillips-Universität Marburg, Germany.

Gawlick, K. 1997. Die Trilobiten der Devon/Karbon-Grenze und des basalen Unter-Karbon (Gattendorfia-Stufe) im Profil Pfaffenberg bei Saalfeld-Obernitz. In Blumenstengel, H., Weyer, D., and Bartzsch, K.: Exkursion A4. Stratigraphie, Fazies und Tektonik des Oberdevon und Unterkarbon im Thüringer Schiefergebirge p. 83-99. In Lützner, H. and Seidel, G. (eds.), Regionale Geologie von Mitteleuropa, Exkursionsführer; 149. 
Hauptversammlung der Deutschen Geologischen Gesellschaft, Jena 1997. Schriftenreihe der Deutschen Geologischen Gesellschaft, 3.

Gawlick, K. 2002. Trilobiten-Zonen, p. 696. In Amler, M.R.W. and Gereke, M. (eds.), KarbonKorrelationstabelle (KKT). Senckenbergiana Lethaea, 82. https://doi.org/10.1007/ bf03042955

George, T.N. 1931. Ambocoelia Hall and certain similar British Spiriferidae. Quarterly Journal of the Geological Society of London, 87:30-61. https://doi.org/10.1144/gsl.jgs.1931.087.0104.05

Gereke, M. 2004. Das Profil Kahlleite Ost - die stratigraphische Entwicklung einer Tiefschwelle im Oberdevon des Bergaer Sattels (Thüringen). Geologica et Palaeontologica, 38:1-31.

Girard, C., Cornée, J.-J., Charruault, A.-L., Corradini, C., Weyer, D., Bartzsch, K., Joachimski, M., and Feist, R. 2016. Conodont biostratigraphy and palaeoenvironmental trends during the Famennian (Late Devonian) in the Thuringian Buschteich section (Germany). Newsletters on Stratigraphy, 50:71-89. https://doi.org/10.1127/nos/2016/0318

Girty, G.H. 1926. Mississippian formations of San Saba County, Texas, III. United States Geological Survey Professional Paper, 146:24-43.

Girty, G.H. 1938. Descriptions of a new genus and a new species of Carboniferous brachiopod. Journal of the Washington Academy of Sciences, 28:278-284.

Gischler, E. 1994. A new occurrence of 'Spirifer' macrogaster F. A. Roemer 1852 (Brachiopoda) in Lower Carboniferous limestones on top of the Iberg Reef, Germany. Neues Jahrbuch für Geologie und Paläontologie, 1994:321-328.

Gorjansky, V.Y. and Popov, L.E. 1985. The morphology, systematic position, and origin of inarticulate brachiopods with carbonate shells. Paleontologicheskii Zhurnal, 1985(1):3-13. (In Russian)

Gräbe, R. 1962. Beziehungen zwischen der tektonischen und faziellen Entwicklung des Oberdevons und Unterkarbons sowie zur Genese der Eisenerze vom Lahn-Dill-Typus am NW-Rand des Bergaer Sattels (Thüringisches Schiefergebirge). Freiberger Forschungshefte, Reihe C, 140:1-83.

Graham, D.K. 1970. Scottish Carboniferous Lingulacea. Bulletin of the Geological Survey of Great Britain, 31:139-184.

Gray, J.E. 1840. Brachiopoda, p. 151. In Anonymous, Synopsis of the Contents of the British Museum. Forty-second Edition. G. Woodfall, London. https://doi.org/10.5962/bhl.title.144636

Groos-Uffenorde, H. 1993. Ostracods from the Devonian/Carboniferous boundary and their representation in stereo pairs. Göttinger Arbeiten zur Geologie und Paläontologie, 58:115122.

Gründel, J. 1961. Zur Biostratigraphie und Fazies der Gattendorfia-Stufe in Mitteldeutschland unter besonderer Berücksichtigung der Ostracoden. Freiberger Forschungshefte, Reihe $C$, 111:53-173

Gründel, J. 1962. Zur Taxionomie der Ostracoden der Gattendorfia-Stufe Thüringens. Freiberger Forschungshefte, Reihe C, 151:51-105.

Grüneberg, H. 1925. Beiträge zur Kenntnis des Oberdevons der Herzkamper Mulde. Jahresberichte des Naturwissenschaftlichen Vereins von Elberfeld, 15:48-96.

Grunt, T.A. 1965. Superfamily Athyridacea, p. 237-253. In Ruzhencev, V.E and Sarycheva, T.G. (eds.), Evolution and Change of Marine Organisms at the Paleozoic-Mesozoic Boundary. Akademiia Nauk SSSR, Trudy Paleontologicheskogo Instituta, 108.

Grunt, T.A. and Weyer, D. 2016. New data on some Middle Devonian Athyridida (Brachiopoda) from the Rhenish Massif, Germany. Palaeoworld, 25:616-631. https://doi.org/10.1016/ j.palwor.2016.05.001

Hahn, G. and Hahn, R. 2008. Catalogus trilobitorum cum figuris (Trilobites carbonici et permici, VI. Cummingellinae), p. 1-433. In Riegraf, W. (ed.), Fossilium Catalogus, I: Animalia, Pars 145. Backhuys Publishers, Leiden and Margraf Publishers, Weikersheim.

Hahn, G., Hahn, R., and Gawlick, K. 1995. Phylogenie und Systematik von Diacoryphe und verwandten Gattungen (Trilobita; Unter-Karbon). Geologica et Palaeontologica, 29:145-191.

Halamski, A.T. and Baliński, A. 2009. Latest Famennian brachiopods from Kowala, Holy Cross Mountains, Poland. Acta Paleontologica Polonica, 54:289-306. https://doi.org/10.4202/ app.2007.0066

Hall, J. 1858. Descriptions of new species of fossils from the Carboniferous rocks of Indiana and Illinois. Transactions of the Albany Institute, 4:1-36. 
Hall, J. and Clarke, J.M. 1890. Extract. Palaeontology of New York, Vol. 8, art 1. Charles van Benthuysen and Sons, Albany.

Hartenfels, S. and Becker, R.T. 2016. Age and correlation of the transgressive Gonioclymenia Limestone (Famennian, Tafilalt, eastern Anti-Atlas, Morocco). Geological Magazine. https:// doi.org/10.1017/S0016756816000893

Havlíček, V. 1979. Upper Devonian and lower Tournaisian Rhynchonellida in Czechoslovakia. Vĕstník Ústředního ústavu Geologického, 54:87-101.

Havlíček, V. 1982. New Pugnacidae and Plectorhynchellidae (Brachiopoda) in the Silurian and Devonian Rocks of Bohemia. Vestník Ústredního ústavu Geologického, 57:111-114.

Hedberg, H.D. 1976. International Stratigraphic Guide (A Guide to Stratigraphic Classification, Terminology and Procedure). Wiley, New York.

Holmer, L.E. and Popov, L.E. 2000. Lingulata, p. 30-146. In Kaesler, R.L. (ed.), Treatise on Invertebrate Paleontology, Part H (Revised), Brachiopoda, 2. Geological Society of America and University of Kansas Press, Boulder, Colorado, and Lawrence, Kansas, 1-3226.

Ivanova, E.A. 1972. Main features of spiriferid evolution (Brachiopoda). Paleontologicheskii Zhurnal, 1972(3):28-42. (In Russian)

Ji, Qiang 1985. Study on the Phylogeny, Taxonomy, Zonation and Biofacies of Siphonodella (Conodonta). Bulletin of the Institute of Geology, Chinese Academy of Geological Sciences, 11:51-75. (In Chinese)

Johnson, J.G. and Hou, H.-F. 2006. Delthyridoidea, p. 1825-1847. In Kaesler, R.L. (ed.), Treatise on Invertebrate Paleontology, Part H (Revised), Brachiopoda, 5. Geological Society of America and University of Kansas Press, Boulder, Colorado, and Lawrence, Kansas, 1-3226.

Jux, U. and Krath, J. 1974. Die Fauna aus dem mittleren Oberdevon (Nehden-Stufe) des südwestlichen Bergischen Landes (Rheinisches Schiefergebirge). Palaeontographica, Abteilung A, 147:115-168.

Kaiser, S.I., Aretz, M., and Becker, R.T. 2016. The global Hangenberg Crisis (DevonianCarboniferous transition): review of a first-order mass extinction. Geological Society London Special Publications, 423:387-437. https://doi.org/10.1144/sp423.9

Kaiser, S.I., Becker, R.T., Steuber, T., and Aboussalam, S.Z. 2011. Climate-controlled mass extinctions, facies, and sea-level changes around the Devonian-Carboniferous boundary in the eastern Anti-Atlas (SE Morocco). Palaeogeography, Palaeoclimatology, Palaeoecology, 310:340-364. https://doi.org/10.1016/j.palaeo.2011.07.026

Kononova, L.I. and Weyer, D. 2013. Upper Famennian conodonts from the Breternitz Member (Upper Clymeniid Beds) of the Saalfeld region, Thuringia (Germany). Freiberger Forschungshefte, Reihe C, 545:15-97.

Korn, D. 1992. Heterochrony in the evolution of Late Devonian Ammonoids. Acta Palaeontologica Polonica, 37:21-36.

Korn, D. 2006. Lithostratigraphische Neugliederung der Kulm-Sedimentgesteine im Rheinischen Schiefergebirge, p. 379-383. In Korn, D., Clausen, C.-D., and Luppold, F.W. (eds.), Die Devon/Karbon-Grenze im Rheinischen Schiefergebirge. Geologie und Paläontologie in Westfalen, 29.

Korn, D. and Weyer, D. 2003. High resolution stratigraphy of the Devonian-Carboniferous transitional beds in the Rhenish Mountains. Mitteilungen aus dem Museum für Naturkunde in Berlin, Geowissenschaftliche Reihe, 6:79-124. https://doi.org/10.5194/fr-6-79-2003

Kuhn, O. 1949. Lehrbuch der Paläozoologie. E. Schweizerbart, Stuttgart.

Lange, W. 1929. Zur Kenntnis des Oberdevons am Enkeberg und bei Balve (Sauerland). Abhandlungen der Preußischen Geologischen Landesanstalt, Neue Folge, 119:1-132.

Lazarev, S.S. and Suur'suren, Sh. 1992. New productids (Brachiopoda) from the Carboniferous of Mongolia. Sovnestnaya Rossiiskomongol'skaya Paleontologicheskaya Ekspeditsiya, Trudy, 41:61-70. (In Russian)

Lee, D.E., Mackinnon, D.I., Smirnova, T.N., Baker, P.G., Jin, Y.-G., and Sun, D.-L. 2006. Terebratulida, p. 1965-2250. In Kaesler, R.L. (ed.), Treatise on Invertebrate Paleontology, Part H (Revised), Brachiopoda, 5. Geological Society of America and University of Kansas Press, Boulder, Colorado, and Lawrence, Kansas, 1-3226.

Lerosey-Aubril, R. 2006. Ontogeny of Drevermannia and the origin of blindness in Late Devonian proetoid trilobites. Geological Magazine, 143:89-104. https://doi.org/10.1017/ s0016756805001421 
Liebe, K.T. and Zimmermann, E. 1888. Erläuterungen zur Geologischen Specialkarte von Preussen und den Thüringischen Staaten [1:25000]. Lieferung 40. Blatt Probstzella. Königlich Preussische Geologische Landesanstalt, Berlin.

M'Coy, F. 1841. A Catalogue of the Museum of the Geological Society of Dublin. Hodges and Smith, Dublin.

M'Coy, F. 1852. On some new Brachiopoda from the Carboniferous limestone. Annals and Magazine of Natural History, 10:421-429. https://doi.org/10.1080/03745485609495734

Martínez Chacón, M.L. 1979. Braquiópodos Carboníferos de la Cordillera Cantábrica (Orthida, Strophomenida y Rhynchonellida). Memoria del Instituto Geológico y Minero de España, 96:1-291.

Martínez Chacón, M.L. and Delvolvé, J.J. 1986. Une faune de rhynchonellidés du Carbonifère antévarisque des Pyrénées centrales françaises. Geobios, 19:825-845. https://doi.org/ 10.1016/s0016-6995(86)80110-3

Meek, F.B. 1875. A report on some of the invertebrate fossils of the Waverly Group and coalmeasures of Ohio. Geological Survey of Ohio, Report, 2:269-347.

Menke, C.T. 1828. Synopsis methodica molluscorum generum omnium et specierum earum quae in Museo Menkeano adservantur; cum synonymia critica et novarum specierum diagnosibus. G. Uslar, Pyrmonti. https://doi.org/10.5962/bhl.title.13182

Mergl, M. 2006. A review of Silurian discinoid brachiopods from historical British localities. Bulletin of Geosciences, 81:215-236. https://doi.org/10.3140/bull.geosci.2006.04.215

Meyer, H. 1920. Der Bohlen bei Saalfeld in Thüringen. R. Clauss, Saalfeld.

Mortelmans, G. 1969. L'étage Tournaisien dans sa localité-type. Compte-Rendu du 6ème Congrès International de Stratigraphie et de Géologie du Carbonifère (Sheffield 1967), 1:1944.

Mottequin, B. 2008. New observations on Upper Devonian brachiopods from the Namur-Dinant Basin (Belgium). Geodiversitas, 30:455-537.

Mottequin, B. 2010. Mississippian (Tournaisian) brachiopods from the Hook Head Formation, County Wexford (south-east Ireland). Special Papers in Palaeontology, 84:243-285.

Mottequin, B. and Brice, D. 2016. Upper and uppermost Famennian (Devonian) brachiopods from north-western France (Avesnois) and southern Belgium. Geologica Belgica, 19:121134. https://doi.org/10.20341/gb.2016.004

Mottequin, B., Brice, D., and Legrand-Blain, M. 2014. Biostratigraphic significance of brachiopods near the Devonian-Carboniferous boundary. Geological Magazine, 151:216228. https://doi.org/10.1017/s0016756813000368

Mottequin, B. and Legrand-Blain, M. 2010. Late Tournaisian (Carboniferous) brachiopods from Mouydir (Central Sahara, Algeria). Geological Journal, 45:353-374. https://doi.org/10.1002/ gj.1176

Mottequin, B., Malti, F.Z., Benyoucef, M., Crônier, C., Samar, L., Randon, C., and Brice, D. 2015a. Famennian rhynchonellides (Brachiopoda) from deep-water facies of the Ougarta Basin (Saoura Valley, Algeria). Geological Magazine, 152:1009-1024. https://doi.org/ $10.1017 / \mathrm{s} 0016756814000697$

Mottequin, B., Sevastopulo, G., and Simon, E. 2015b. Micromorph brachiopods from the late Asbian (Mississippian, Viséan) from northwest Ireland (Gleniff, County Sligo). Bulletin of Geosciences, 90:307-330. https://doi.org/10.3140/bull.geosci.1512

Mottequin, B. and Simon, E. 2017. Revision of some spiriferide and spiriferinide brachiopods from the historical type area of the Tournaisian Stage (Carboniferous, southern Belgium). Paläontologische Zeitschrift, 91:473-496. https://doi.org/10.1007/s12542-017-0359-3

Mottequin, B. and Weyer, D. 2019. On some Mississippian (Carboniferous) brachiopods from neptunian dykes of the Harz Mountains (central Germany). Palaeobiodiversity and Palaeoenvironments. https://doi.org/10.1007/s12549-018-0360-1

Muir-Wood, H.M. 1955. A History of the Classification of the Phylum Brachiopoda. British Museum (Natural History), London.

Muir-Wood, H.M. 1962. On the Morphology and Classification of the Brachiopod Suborder Chonetoidea. British Museum (Natural History), London.

Muir-Wood, H.M. and Cooper, G.A. 1960. Morphology, classification and life habits of the Productoidea (Brachiopoda). Memoir of the Geological Society of America, 81:1-447. https:// doi.org/10.1130/mem81-p1 
Müller, H. 2004. Late Famennian brachiopods from the Refrath 1 Borehole (Bergisch GladbachPaffrath Syncline; Ardennes-Rhenish Massif, Germany). Courier Forschungsinstitut Senckenberg, 251:135-143.

Müller, K.J. 1956. Cephalopodenfauna und Stratigraphie des Oberdevons von Schleiz und Zeulenroda in Thüringen. Beiheft Geologisches Jahrbuch, 20:1-93.

Münster, G. 1840. Die Versteinerungen des Uebergangskalkes mit Clymenien und Orthoceratiten von Oberfranken. Beiträge zur Petrefacten-Kunde, 3:33-121.

Murchison, R.I. 1839. The Silurian System, Founded on Geological Researches In the Counties of Salop, Hereford, Radnor, Montgomery, Caermarthen, Brecon, Pembroke, Monmouth, Gloucester, Worcester, and Stafford; with Descriptions of the Coal-fields and Overlying Formations. 2 vol. John Murray, London. https://doi.org/10.5962/bhl.title.88029

Neal, M.L. and Hannibal, J.T. 2000. Paleoecologic and taxonomic implications of Sphenothallus and Sphenothallus-like specimens from Ohio and areas adjacent to Ohio. Journal of Paleontology, 74:369-380. https://doi.org/10.1017/s0022336000031644

North, F.J. 1920. On Syringothyris Winchell and certain Carboniferous Brachiopoda referred to Spiriferina d'Orbigny. Quarterly Journal of the Geological Society of London, 76:162-227. https://doi.org/10.1144/gsl.jgs.1920.076.01-04.06

Oppenheimer, J. 1916. Das Oberdevon von Brünn. Verhandlungen des Naturforschenden Vereines in Brünn, 54:1-43.

Owen, E.F. 1988. Cenomanian brachiopods from the Lower Chalk of Britain and northern Europe. Bulletin of the British Museum (Natural History) Geology, 44(2):65-175.

Paeckelmann, W. 1913. Das Oberdevon des Bergischen Landes. Abhandlungen der Königlich Preussischen Geologischen Landesanstalt, 70:3-356.

Paeckelmann, W. 1930. Die Fauna des deutschen Unterkarbons. Die Brachiopoden, I: Die Orthiden, Strophomeniden und Choneten des Mittleren und Oberen Unterkarbons. Abhandlungen der Preussischen Geologischen Landesanstalt, Neue Folge, 122:143-326.

Paeckelmann, W. 1931. Die Fauna des deutschen Unterkarbons, II: Die Brachiopoden des deutschen Unterkarbons. Part 2. Die Productinae und Productus-ahnlichen Chonetinae. Abhandlungen der Preussischen Geologischen Landesanstalt, Neue Folge, 136:1-440.

Paeckelmann, W. and Schindewolf, O.H. 1937. Die Devon-Karbon-Grenze. Compte Rendu (2) du Cinquième Congrès pour l'Avancement des Etudes de Stratigraphie du Carbonifère (Heerlen 1935), 2:703-714.

Paproth, E., Feist, R., and Flajs, G. 1991. Decision on the Devonian-Carboniferous boundary stratotype. Episodes, 14:331-336.

Paul, H. 1937. Die Transgression der Viséstufe am Nordrande des Rheinischen Schiefergebirges. Abhandlungen der Preussischen Geologischen Landesanstalt, Neue Folge, 179:5-117.

Paul, H. 1939. Die Etrœungt-Schichten des Bergischen Landes. Jahrbuch der Preussischen Geologischen Landesanstalt, 59:647-726.

Péneau, J. 1928. Etudes stratigraphiques et paléontologiques dans le Sud-Est du Massif armoricain (Synclinal de St-Julien-de Vouvantes). Bulletin de la Société des Sciences Naturelles de l'Ouest de la France (série 4), 8:1-300.

Pérez-Huerta, A. and Sheldon, N.D. 2006. Pennsylvanian sea level cycles, nutrient availability and brachiopod paleoecology. Palaeogeography, Palaeoclimatology, Palaeoecology, 230:264-279. https://doi.org/10.1016/j.palaeo.2005.07.020

Pfeiffer, H. 1954. Der Bohlen bei Saalfeld/Thür. Beiheft zur Zeitschrift Geologie, 1954(11):3-105.

Pfeiffer, H., Blumenstengel, H., and Wiefel, H. 1995. Dinant (Unterkarbon), p. 147-166. In Seidel, G. (ed.), Geologie von Thüringen. E. Schweizerbart'sche Verlagsbuchhandlung, Stuttgart.

Phillips, J. 1836. Illustrations of the Geology of Yorkshire, Part 2. The Mountain Limestone District. John Murray, London.

Phillips, J. 1841. Figures and Descriptions of the Palaeozoic Fossils of Cornwall, Devon, and West Somerset. Longman, Brown, Green and Longmans, London.

Qian, W.-L. and Roberts, J. 1995. Brachiopods of the Early Carboniferous Schellwienella burlingtonensis Zone in eastern Australia. Alcheringa, 19:255-289. https://doi.org/10.1080/ 03115519508619509

Rachebœuf, P.R. 2000. Chonetidina, 362-423. In Kaesler, R.L. (ed.), Treatise on Invertebrate Paleontology, Part H (Revised), Brachiopoda, 2. Geological Society of America and University of Kansas Press, Boulder, Colorado, and Lawrence, Kansas, 1-3226. 
Rachebœuf, P.R. 2007. Chonetidina, 2628-2638. In Kaesler, R.L. and Selden, P.A. (eds.), Treatise on Invertebrate Paleontology, Part H (Revised), Brachiopoda, 6. Geological Society of America and University of Kansas Press, Boulder, Colorado, and Lawrence, Kansas, 13226.

Racki, G. 1989. Articulate brachiopods and Late Paleozoic dysaerobic biofacies. Lethaia, 22:148. https://doi.org/10.1111/j.1502-3931.1989.tb01676.x

Renier, A., Stockmans, F., Demanet, F., and Van Straelen, V. 1938. Flore et Faune Houillères de la Belgique. Introduction à L'étude Paléontologique du Terrain Houiller. Patrimoine du Musée royal d'Histoire naturelle de Belgique, Bruxelles.

Renz, C. 1914. Neue Arten aus dem Clymenienkalk von Ebersdorf in Schlesien. Jahrbuch der Preussischen Geologischen Landesanstalt, 34:99-129.

Rhodes, F.H.T., Austin, R.L., and Druce, E.C. 1969. British Avonian (Carboniferous) conodont faunas, and their value in local and intercontinental correlation. Bulletin of the British Museum (Natural History), Geology, supplement, 5:1-313.

Richter, R. 1848. Beitrag zur Paläontologie des Thüringer Waldes. Die Grauwacke des Bohlens und des Pfaffenberges bei Saalfeld. I. Fauna. Arnoldi, Dresden/Leipzig. https://doi.org/ 10.5962/bhl.title.14411

Richter, R. 1856. Beitrag zur Paläontologie des Thüringer Waldes. Erster Teil. Denkschriften der kaiserlichen Akademie der Wissenschaften Wien, Mathematisch-naturwissenschaftliche Classe, 11:87-138.

Richter, R. 1869. Devonische Entomostraceen in Thüringen. Zeitschrift der deutschen geologischen Gesellschaft,21:757-776.

Richter, Ru. and Richter, E. 1926. Die Trilobiten des Oberdevons. Abhandlungen der Preussischen Geologischen Landesanstalt, Neue Folge, 99:1-314.

Richter, Ru. and Richter, E. 1951.Der Beginn des Karbons im Wechsel der Trilobiten. Senckenbergiana, 32(1/4):219-266.

Roberts, J. 1963. A Lower Carboniferous fauna from Lewinsbrook, New South Wales. Journal and Proceedings, Royal Society of New South Wales, 97:1-29.

Roberts, J. 1971. Devonian and Carboniferous brachiopods from the Bonaparte Gulf Basin, northwestern Australia. Bulletin of the Bureau of Mineral Resources, Geology and Geophysics, 122:1-319.

Roberts, J. 1976. Carboniferous chonetacean and productacean brachiopods from eastern Australia. Palaeontology, 19:17-77.

Rodriguez, J. and Gutschick, R.C. 1968. Productina, Cyrtina, and Dielasma (Brachiopoda), from the Lodgepole Limestone (Mississippian) of southwestern Montana. Journal of Paleontology, 42:1027-1032.

Roemer, F.A. 1852. Beiträge zur geologischen Kenntniss des nordwestlichen Harzgebirges. Palaeontographica, 3:1-67.

Rowley, R.R. 1900. Descriptions of new species of fossils from the Devonian and Subcarboniferous [sic] rocks of Missouri. The American Geologist, 25:261-273.

Rozman, H.S. 1962. Stratigraphy and brachiopods of the Famennian stage of Mugodzhars and adjacent areas. Trudy Geologičeskogo Instituta AN SSSR, 50:1-187. (In Russian)

Rzhonsnitskaya, M.A. 1956. Systematization of Rhynchonellida, p. 125-126. In Guzmán, E. (ed.), Resúmenes de Los Trabajos Presentados. International Geological Congress, Mexico, Report, 20.

Sahni, M.R. 1929. A monograph of the Terebratulidae of the British Chalk. Palaeontographical Society Monograph, 81:1-62.

Sandberg, C.A., Ziegler, W., Leuteritz, K., and Brill, S.M. 1978. Phylogeny, speciation, and zonation of Siphonodella (Conodonta, Upper Devonian and Lower Carboniferous). Newsletters on Stratigraphy, 7:102-120. https://doi.org/10.1127/nos/7/1978/102

Sartenaer, P. 1977. Un nouveau genre de rhynchonellidé de la fin du Frasnien. Annales de la Société Géologique du Nord, 97:67-76.

Sartenaer, P. 1997. Novaplatirostrum, late Famennian rhynchonellid genus from Sauerland and Thuringia. Bulletin de l'Institut Royal des Sciences naturelles de Belgique, Sciences de la Terre, 67:25-37.

Sartenaer, P. 1998a. Leptoterorhynchus, new middle Famennian rhynchonellid genus from Poland and Germany. Bulletin de I'Institut Royal des Sciences naturelles de Belgique, Sciences de la Terre, 68:121-128. 
Sartenaer, P. 1998b. The presence in Morocco of the late Famennian genus Hadyrhyncha Havlíček, 1979 (rhynchonellid brachiopod). Bulletin de l'Institut Royal des Sciences Naturelles de Belgique, Sciences de la Terre, 68:115-120.

Sartenaer, P. 1999. Tetragonorhynchus, new late Famennian rhynchonellid genus from Maider, southern Morocco, and Tetragonorhynchidae n. fam. Bulletin de l'Institut Royal des Sciences Naturelles de Belgique, Sciences de la Terre, 69:67-75.

Sartenaer, P. 2000. Phacoiderhynchus, a new middle Famennian rhynchonellid genus from the Anti-Atlas, Morocco, and Phacoiderhynchidae n. fam. Bulletin de l'Institut Royal des Sciences Naturelles de Belgique, Sciences de la Terre, 70:75-88.

Sartenaer, P., Racki, G., and Szulczewski, M. 1998. The Late Frasnian rhynchonellid genus Pammegetherhynchus (Brachiopoda) in Poland, and its relevance to the Kellwasser Crisis. Acta Palaeontologica Polonica, 43:379-394.

Sartenaer, P. and Xu Han-kui 1990. The Upper Famennian Rhynchonellid genus Planovatirostrum Sartenaer, 1970 from Africa, China, Europe and the USSR. Bulletin de I'Institut Royal des Sciences Naturelles de Belgique, Sciences de la Terre, 59: 37-48 (dated 1989).

Sarycheva, T.G. and Sokolskaya, A.N. 1959. On the classification of pseudopunctate brachiopods. Akademiia Nauk SSSR, Doklady, 125:181-184. (In Russian)

Savage, N.M. 2007. Rhynchonellida (part), p. 2703-2716. In Selden, P.A. (ed.), Treatise on Invertebrate Paleontology, Part H (Revised), Brachiopoda, 6. Geological Society of America and University of Kansas Press, Boulder, Colorado, and Lawrence, Kansas, 1-3226.

Savage, N.M., Manceñido, M.O., Owen, E.F., Carlson, S.J., Grant, R.E., Dagys, A.S., and Sun, D-L. 2002. Rhynchonellida, p. 1027-1376. In Kaesler, R.L. (ed.), Treatise on Invertebrate Paleontology, Part H (Revised), Brachiopoda, 4. Geological Society of America and University of Kansas Press, Boulder, Colorado, and Lawrence, Kansas, 1-3226.

Schindewolf, O.H. 1920. Neue Beiträge zur Kenntnis der Stratigraphie und Paläontologie des deutschen Oberdevons. Senckenbergiana, 2(3/4):114-129.

Schindewolf, O.H. 1921. Versuch einer Paläogeographie des europäischen Oberdevonmeeres. Zeitschrift der Deutschen Geologischen Gesellschaft, 73(3):137-223.

Schindewolf, O.H. 1923. Beiträge zur Kenntnis des Paläozoikums in Oberfranken, Ostthüringen und dem Sächsischen Vogtlande. I. Stratigraphie und Ammoneenfauna des Oberdevons von Hof a.S. Neues Jahrbuch für Mineralogie, Geologie und Paläontologie, Beilage-Band, 49:250-357, 393-509.

Schindewolf, O.H. 1924. Bemerkungen zur Stratigraphie und Amoneenfauna des Saalfelder Oberdevons. Senckenbergiana, 6:95-113.

Schindewolf, O.H. 1928. Die Liegendgrenze des Karbons im Lichte biostratigraphischer Kritik, p. 651-661. In Jongmans, W.J. (ed.), Congrès pour l'étude de la Stratigraphie du Carbonifère dans les Différents Centres Houillers de l'Europe. Congrès pour l'Avancement des études de Stratigraphie Carbonifère. Heerlen, 7-11 Juin 1927. Compte Rendu. Vaillant-Carmanne, Liège.

Schindewolf, O.H. 1937. Zur Stratigraphie und Paläontologie der Wocklumer Schichten (Oberdevon). Abhandlungen der Preussischen Geologischen Landesanstalt, Neue Folge, 178:1-132.

Schindewolf, O.H. 1952. Über das Oberdevon und Unterkarbon von Saalfeld in Ostthüringen. Eine Nachlese zur Stratigraphie und Ammoneen-Fauna. Senckenbergiana, 32(5/6):281-306.

Schmidt, H. 1923. Neubestimmung der Gonioclymenienfauna von Saalfeld. Senckenbergiana, 5 (12):56-59.

Schmidt, H. 1924. Zwei Cephalopoden-Fauna an der Devon-Carbongrenze im Sauerland. Jahrbuch der Preussischen Geologischen Landesanstalt, 44:98-171.

Schuchert, C. 1929. Classification of brachiopod genera, fossil and Recent, p. 10-25. In Schuchert, C. and Levene, C.M., Brachiopoda (Generum et Genotyporum Index et Bibliographia). In Pompeckj, J.F. (ed.), Fossilium Catalogus, I: Animalia, pars 42. W. Junk, N.V., Berlin.

Schuchert, C. and Cooper, G.A. 1932. Brachiopod genera of the suborders Orthoidea and Pentameroidea. Memoirs of the Peabody Museum of Natural History, 4:1-270. https://doi.org/ 10.5962/bhl.title.5732

Selwood, E.B. 1960. Ammonoids and Trilobites from the Upper Devonian and Lowest Carboniferous of the Launceston Area of Cornwall. Palaeontology, 3(2):153-185. 
Spalletta, C., Perri, M.C., Over, D.J., and Corradini, C. 2017. Famennian (Upper Devonian) conodont zonation: revised global standard. Bulletin of Geosciences, 92(1):31-57. https:// doi.org/10.3140/bull.geosci.1623

Sowerby, J. 1812-1815. The Mineral Conchology of Great Britain; or Coloured Figures and Descriptions of those Remains of Testaceous Animals or Shells, Which Have Been Preserved at Various Times and Depths in the Earth, Vol. 1. Published by the author, London. https://doi.org/10.5962/bhl.title.14408

Sowerby, J. 1821-1822. he Mineral Conchology of Great Britain; or Coloured Figures and Descriptions of those Remains of Testaceous Animals or Shells, Which Have Been Preserved at Various Times and Depths in the Earth, Vol. 4. Published by the author, London. https://doi.org/10.5962/bhl.title.14408

Sowerby, J. de C. 1840. Explanation of the plates and woodcuts. In Sedgwick, A. and Murchison, R.I. (eds.), On the physical structure of Devonshire, and on the subdivisions and geological relations of its older stratified deposits. Transactions of the Geological Society of London (2nd series), 5:633-703. https://doi.org/10.1144/transgslb.5.3.633

Sutton, A.H. 1938. Taxonomy of Mississippian Productidae. Journal of Paleontology, 12:537569.

Tietze, E. 1870. Ueber die devonischen Schichten von Ebersdorf unweit Neurode in der Grafshaft Glatz, eine geognostisch-palaontologische Monographie. Palaeontographica, 19:103-158.

Vangerow, E.F. 1959. Die Fauna des westdeutschen Oberkarbons, I: Die inarticulaten Brachiopoden des westdeutschen flötzführenden Oberkarbons. Palaeontographica, Abteilung A, 113:36-60.

Veevers, J.J. 1959. Devonian brachiopods from the Fitzroy Basin, Western Australia. Bureau of Mineral Resources, Bulletin of Australian Geology and Geophysics, 45:1-220.

Vöhringer, E. 1960. Die Goniatiten der unterkarbonischen Gattendorfia-Stufe im Hönnetal (Sauerland). Fortschritte in der Geologie von Rheinland and Westfalen, 3:107-196.

Waagen, W.H. 1883. Salt Range fossils, I. Productus-Limestone Fossils. Brachiopoda. Palaeontologia Indica (Series 13), 4:391-546.

Waagen, W.H. 1885. Salt Range fossils, I. Productus Limestone fossils. Brachiopoda. Palaeontologia Indica (Series 13), 5:729-770.

Weber, H. 1955. Einführung in die Geologie Thüringens. VEB Deutscher Verlag der Wissenschaften, Berlin.

Wedekind, R. 1908. Die Cephalopodenfauna des höheren Oberdevon am Enkenberg. Neues Jahrbuch für Mineralogie, Geologie und Paläontologie, 26:565-635.

Wedekind, R. 1914. Monographie der Clymenien des Rheinischen Gebirges. Abhandlungen der Königlichen Gesellschaft der Wissenschaften zu Göttingen (Berlin), mathematischphysikalische Klasse, Neue Folge, 10(1):1-73.

Wedekind, R. 1918. Die Genera der Palaeoammonoidea (Goniatiten) (mit Ausschluß der Mimoceratidae, Glyphioceratidae und Prolecanitidae). Palaeontographica, 62:85-184.

Wei-Haas, M.L., Glumac, B., and Curran, H.A. 2011. Sphenothallus-like fossils from the Martinsburg Formation (Upper Ordovician), Tennessee, USA. Journal of Paleontology, 85:353-359. https://doi.org/10.1666/09-146.1

Weller, S. 1909. The fauna of the Fern Glen Formation. Bulletin of the Geological Society of America, 20:265-332. https://doi.org/10.1130/gsab-20-265

Weller, S. 1910. Internal characters of some Mississippian rhynchonelliform shells. Geological Society of America, Bulletin, 21:497-516. https://doi.org/10.1130/gsab-21-497

Weller, S. 1914. The Mississippian Brachiopoda of the Mississippi Valley Basin. Illinois State Geological Survey Monograph, 1:1-508. https://doi.org/10.5962/bhl.title.37902

Weyer, D. 1965. Triacrinus Münster 1839 (Crinoidea) aus der Wocklumeria-Stufe des thüringischen Oberdevons. Geologie, 14(8):969-981.

Weyer, D. 1971. Neaxon regulus (Rh. Richter, 1848), ein Leitfossil der mitteleuropäischen Wocklumeria-Stufe (Anthozoa, Rugosa; Oberdevon). Geologie, 20(3):292-315.

Weyer, D. 1972. Rozmanaria, ein neues Rhynchonellida-Genus aus dem europäischen Oberfamenne (Brachiopoda, Oberdevon). Geologie, 21:84-99.

Weyer, D. 1976. Ein neues Ammonoidea-Genus aus dem Untertournai des Thüringischen Schiefergebirges. Zeitschrift für geologische Wissenschaften, 4(6), 837-857.

Weyer, D. 1977. Ammonoideen aus dem Untertournai von Schleiz (Ostthüringisches Schiefergebirge). Zeitschrift für geologische Wissenschaften, 5(2):167-185. 
Weyer, D. 1979. Biostratigraphy of the Devonian-Carboniferous boundary in the German Democratic Republic. Comptes Rendus du 8e Congrès International de Stratigraphie du Carbonifère (Moscow 1975), 3:97-104.

Weyer, D. 1981a. Glatziella Renz 1914 (Ammonoidea, Clymeniida) im Oberdevon von Thüringen. Hallesches Jahrbuch für Geowissenschaften, 6:1-12.

Weyer, D. 1981b. Korallen der Devon/Karbon-Grenze aus hemipelagischer CephalopodenFazies im mitteleuropäischen variszischen Gebirge. Bathybalva n. g., Thuriantha n. g. (Rugosa). Freiberger Forschungshefte, Reihe C, 363:111-125.

Weyer, D. 1984. Korallen im Paläozoikum von Thüringen. Hallesches Jahrbuch für Geowissenschaften, 9:5-33.

Weyer, D. 1994. Korallen im Untertournai-Profil von Drewer (Rheinisches Schiefergebirge), p. 177-221. In Korn, D., Clausen, C.-D., and Luppold, F.W. (eds.), Die Devon/Karbon-Grenze im Rheinischen Schiefergebirge. Geologie und Paläontologie in Westfalen, 29.

Weyer, D. 2006. Faunen des deutschen Unterkarbons. 5.1. Korallen, p. 69-88. In Deutsche Stratigraphische Kommission (ed.), Stratigraphie von Deutschland VI, Unterkarbon (Mississippium) (red.: Amler, M.R.W. and Stoppel, D.). Schriftenreihe der Deutschen Gesellschaft für Geowissenschaften, 41.

Williams, A., Carlson, S.J., Brunton, C.H.C., Holmer, L.E., and Popov, L.E. 1996. A supra-ordinal classification of the Brachiopoda. Philosophical Transactions of the Royal Society of London, Series B, 351:1171-1193.

Williams, A. and Harper, D.A.T. 2000. Orthida, p. 714-846. In Kaesler, R.L. (ed.), Treatise on Invertebrate Paleontology, Part H (Revised), Brachiopoda, 3. Geological Society of America and University of Kansas Press, Boulder, Colorado, and Lawrence, Kansas, 1-3226.

Winchell, A. 1863. Description of the fossils of the Yellow Sandstones lying beneath the Burlington Limestone at Burlington, lowa. Proceedings of the Philadelphia Academy of Natural Sciences (Series 2), 7:2-25.

Winchell, A. 1865. Descriptions of new species of fossils, from the Marshall Group of Michigan, and its supposed equivalent, in other states; with notes on some fossils of the same age previously described. Proceedings of the Academy of Natural Sciences of Philadelphia, (Series 2), 17:109-133.

Winkler Prins, C.F. and Martínez Chacón, M.L. 1999. Brachiopods of the Lower Carboniferous Vegamián Formation (Cantabrian Mts, Spain): Part 1. Introduction, Linguliformea. Revista Española de Paleontología, Número extraordinario Homenaje al Prof. J. Truyols, 173-183.

Wongwanich, T., Boucot, A.J., Brunton, C.H.C., House, M.R., and Rachebœuf, P.R. 2004. Namurian Fossils (Brachiopods, Goniatites) from Satun Province, Southern Thailand. Journal of Paleontology, 78:1072-1085. https://doi.org/10.1017/s0022336000043882

Zimmermann, E. 1914. Erläuterungen zur Geologischen Karte von Preussen und Benachbarten Bundesstaaten. Lieferung 40. Blatt Saalfeld a. Saale. 2. Auflage. Königliche Geologische Landesanstalt, Berlin. 